\title{
Envelhecimento das aguardentes
}

\author{
Jayme Rocha de Almeida \\ Professor \\ Otavio Valsecchi e \\ Roberto - Fleury Novais \\ Assistentes
}

Escola Superior de Agricultura

"Luir de Queiroz" da

Universidade de São Paulo

\section{INDICE}

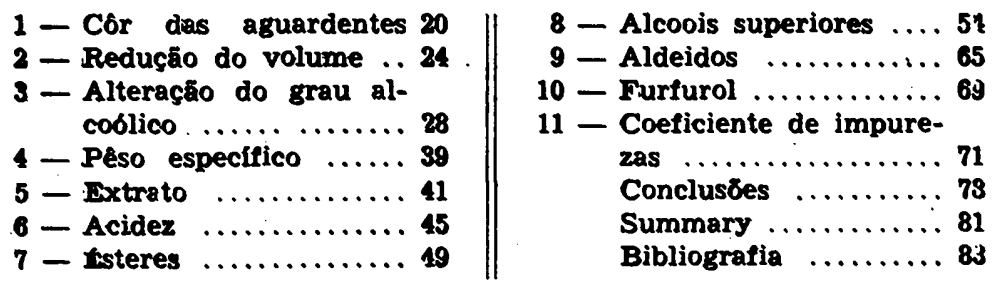


A Sfçăo de Química Tecnologica da Escola Superior de Agricultuxa "Luiz de Queiroz" achou conveniente a realizaçăo dèste trabaliso de investigaçăo, a vista da importáncia económica que a fabricaçáo de aguardente representa no Município de Firacicaba e, nor julgar vantajosa a divulgaçáo de dados cuja natireza é aincia muitc escassa na nossa literatura técnico-cipntifica.

Fita investigacáo prévia nos forneceu dados interessantes e nos orientou para pesquisas futuras, já iniciadas, sóbre o aproveltamento de frutas tropicais para o fabrico de aguardentes finas, te alto valor comercial. As aguardentes, a medida que vão sendo distiladas, săo postas em conservaçăo em barrís de madeira, de 10 litros de capacidade. Para verificar a influência ta madeira na qualidade do produto envelhecido, mandámos preparar 2 lotes : um de 25 unidades, feito de araruva e o outro, também de 25, fabricado com amendoim. intençăo nossa preparar novos lotes com outras esséncias assim que os iniciatos se completem.

Pndemos ccnsiderar como aguardente, todo liquido hidroalcoblıco de pequeno extrato, obtido da distilaçăo de líquidos fermentados e que, apesar do seu elevado teor alcoblico, que ascila entre 50 e $6^{\circ}$ G.L., é susceptivel de ser usado como bebida.

As aguardentes distinguem-se ou diferenciam-se de acordo cin o vinho que lhes deu origem, recebendo muitas vezer: nomes esnecificos. Assim, podemos alinhar a pinga (cana), 0 rum (melaço), o conhaque (vinho de uva), a grapa (uva), o kirsch. (cereja), o quetsh (ameixas), o wisky e o gin (cereais), o pulque (pita), a cidra (maça), etc.

A composição das aguardentes varia consideràvelmente năo só ccm a natureza do mosto, como pela maneira como é cond :ziro o seu proparo, a raça da levedura empregada na ferment 2 çắ do mosto, a idade e o sistema de conservaçăo do produto o olitros fatores mais.

Em relação á natureza do mosto, é claro que variando a comrúsiç:o deste, tem que variar a composição do vinho e ipso fato, a do produto resultante da sua distilaçăo.

Cismpilando diferentes autores, reunimos no quadro abaixo algumás análises de aguardentes de diversas origens com 0 fim de fóralizar a variaçăo da composição das mesmas. 


\section{QUADRO I}

\section{Composigño das Aguardentes}

\begin{tabular}{|c|c|c|c|c|c|c|c|}
\hline$\because: 1.2: 1$ & $\begin{array}{l}\text { Alcool } \\
\% \text { em }\end{array}$ & $\underset{\mathrm{em}}{\mathrm{m} / \mathrm{n}}$ & $\begin{array}{l}\text { agrs. de } \\
100 \mathrm{ce} \text {. }\end{array}$ & $\begin{array}{l}\text { impure } \\
\text { de ále }\end{array}$ & $\begin{array}{l}\text { as volt } \\
\text { ol anid }\end{array}$ & $\begin{array}{l}\text { Sreis } \\
\text { ro }\end{array}$ & im. \\
\hline Crasse & & scidos & tustereal & $\begin{array}{l}\text { Aldei- } \\
\text { dos }\end{array}$ & Furfu- & $\left|\begin{array}{c}\text { Alcosin } \\
\text { sup. }\end{array}\right|$ & \\
\hline $\begin{array}{c}\text { Ag. de pera } \\
" \text { " de maģa } \\
" \quad " \text { Borgonha } \\
" \quad " \text { de Portugal } \\
" \quad \text { Auvernia } \\
" \quad \text { Piemonte }\end{array}$ & $\begin{array}{l}64,60 \\
60,60 \\
51,50 \\
50,00 \\
49,7 \\
43,11\end{array}$ & $\begin{array}{r}20,1 \\
98,2 \\
104,8 \\
250,2 \\
72,4 \\
138,0\end{array}$ & $\begin{array}{l}390,2 \\
204,6 \\
20,0,9 \\
549,1 \\
212,7 \\
320,0\end{array}$ & $\begin{array}{r}10,1 \\
32,5 \\
93,0 \\
100,0 \\
206,0 \\
36,0\end{array}$ & $\begin{array}{l}0,5 \\
1,1 \\
0,8 \\
0,5 \\
1,0 \\
-\end{array}$ & $\begin{array}{l}217,1 \\
148,3 \\
120,0 \\
100,0 \\
243,0 \\
416,5\end{array}$ & $\begin{array}{r}708,6 \\
701,7 \\
524,5 \\
1.008 .8 \\
855,1 \\
912,0\end{array}$ \\
\hline $\begin{array}{c}\text { Conh. piemontes } \\
n \quad \text { conegliano } \\
" \quad \text { sardo } \\
n \quad \text { irances } \\
" \quad \text { siciliano }\end{array}$ & $\begin{array}{l}49,50 \\
48,40 \\
48,15 \\
47,80 \\
45,41\end{array}$ & $\begin{array}{r}29,0 \\
89,0 \\
79,0 \\
107,7 \\
90,5\end{array}$ & $\begin{array}{r}90,0 \\
161,9 \\
189,0 \\
113,9 \\
160.7\end{array}$ & $\begin{array}{l}37,5 \\
11,7 \\
23,8 \\
28,8 \\
23,8\end{array}$ & $\begin{array}{l}2,8 \\
0,4 \\
1,5 \\
2,1 \\
0,8\end{array}$ & $\begin{array}{r}332,0 \\
234,0 \\
249,0 \\
251,6 \\
239,4\end{array}$ & $\begin{array}{l}521.0 \\
498,9 \\
552,3 \\
504,2 \\
514,8\end{array}$ \\
\hline $\begin{array}{c}\text { Rum da Reunião } \\
\text { " Guadalupe } \\
\text { Martinica } \\
\text { " da Jamaica }\end{array}$ & $\begin{array}{l}60,3 \\
59,4 \\
56,1 \\
52,0\end{array}$ & $\begin{array}{r}77,6 \\
78,2 \\
101,4 \\
120,2\end{array}$ & $\begin{array}{r}70,4 \\
30,8 \\
200,8 \\
290,9\end{array}$ & $\begin{array}{l}15,6 \\
32,1 \\
30,7 \\
24,0\end{array}$ & $\begin{array}{l}1,4 \\
1,4 \\
3,0 \\
4,7\end{array}$ & $\begin{array}{l}224,0 \\
304,0 \\
152,6 \\
117,5\end{array}$ & $\begin{array}{l}489.0 \\
452,6 \\
568.9 \\
5664\end{array}$ \\
\hline Kirsch & 50,0 & 118,4 & 2010 & 9,0 & 0,3 & 135,2 & 548,7 \\
\hline Quetsch & 59,5 & 251,3 & 3635 & 19,5 & 0,6 & 269,7 & 901.9 \\
\hline Slivovite & 50,0 & 106,4 & 183.4 & 7,6 & 1,2 & 30,6 & 268,2 \\
\hline Uisque & 48,5 & 48,1 & 50,7 & 12,2 & 1,5 & 296,9 & 415,8 \\
\hline Gin & 43.8 & 36,2 & 73,3 & 7,9 & 1,2 & 72.6 & 218,3 \\
\hline
\end{tabular}

Guando se distila um vinho para obtençăo de aguardente. por mais regular que tenha sido a fermentaçáo do mosto e por mais perfelta que seja a operaçáo de distilaçao, o produto obtido nunca apresenta um sabor agradável, fino, suave ou "redondo".

E.ste fato, naturalmente se verifica devido a sua concentraç alo alcoblica. original multo elevada, a qual comunica á aguardente um sabor seco e ardente, e nunca 0 sabor ou 0 aroma q:e caracterizam as pingas velhas. Im outras palavras, 0 álcocl presente mascara a origem do produto, se de cana, de melaço, de careals ou de mutas. 
Náo $€$ isto que se verifica quando a fermentaçáo foi mal feita ou a dictilação mal conduzida. Neste caso, se bem que seja mascarada a origem do vinho distilado, sobressaem aroma e gôsto. estranhos. Aguardentes cheirando vinagre, mofo ou com gostọ: de azinhsvre såo comuns devido a estạs causas supra citadiss.

$\therefore$ : (i)uar do a aguardente é recém-distilada, a sua composiçăo e muito liversa da jcusada após um perfodo de conservaçăo mais ou menos longo: que, quando nova, se compoe, principalmente, de água e álcool em proporçós variáveis segundo a sua graduaçăo, complementadas por inúmeras outras substancias em quantidade muito menor, embora importantes, tais como 0 aldeido acético o acétal, os ácidos acético, fórmico, butirịco, capréico, caprilico e pelargónico, os ésteres, os alcobis superiores, a glicerina, o furfurol, as bases nitrogenadas e matérlas odorantes de funçסes diversas.

4'stas substancias variam em natureza e proporçăo com a composiç̧o dos mostos, sendo umas, produtos secundários ou acessórios da fermentaçáo; outras săo produtos normais e terceiras, originadas durante a distilaçăo dos vinhos. Formadas no vinho, passam no distllado, seja porque seu ponto de ebulição e pouco elevado em consequencia da sua maior volatilidade, seja porque formam com o álcool e a água misturas azeotropicas de natureza diversa, sendo assim arrastadas mecanicamente.

Ao cnntrário do que se faz nas distllariás que visam a obtençăn if álcool industrial, isento de produtos de cabeça e de caudd. naquelas que produzem exclusivamente aguardente, a distilnçáo precisa ser conduzida' de tal modo que năo se separe apena.: o produto de coraçáo, pois nestas condições, a aguardente seria pobre em substáncias "nåo álcool", cujo conjunto harmonicso contribui para maior valor comercal da aguardente. pois empresta do produto caracteres organolepticos apreciados e exigidos pelos consumidores.

$C$ alieido acético origina-se, segundo TRILLAT, pela açžo oxidante de certas leveduras sobre o álcool :

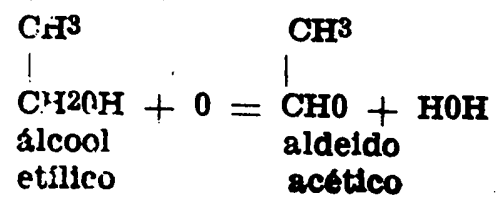


A oxidaça do álcool até a formaçăo deste produto volatil secuncíario ou acessório da fermentaçáo alcoblica pode se rea"lizar também sobre a influência do ar.

O acetal, resulta da ação do aldeido acético, em determinadas condiçóes sôbre o álcool etillico :

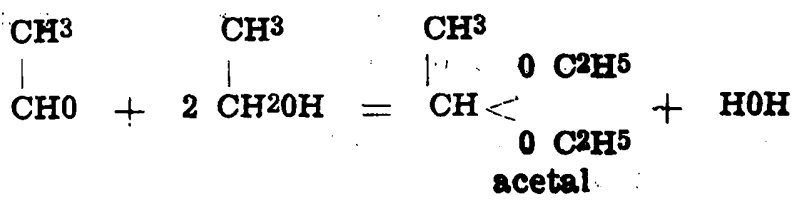

O ácido acético tem origem na atividade vital das células das !eveduras, podendo ser considerado tanto como um acidente di fermentaçáo (açáo de bactéria), como um produto volátil secundário, pois em toda fermentaçáo alcoolica produz-se semnre uma pequena quantidade deste ácido.

$\mathrm{CH}^{3} \mathrm{CH} 2 \mathrm{OH}+\mathrm{O2}^{2}=\underset{\substack{\text { acido } \\ \text { acético }}}{\mathrm{CH}^{3}}+\mathrm{HOH}$

Podemos também admitir a seguinte reaçto:

$\stackrel{\mathrm{CH}}{\mathrm{C}}_{\mathrm{CHO}}+\mathrm{O}=\stackrel{\mathrm{CH}}{\mathrm{COH}}^{\mathrm{C}}$

O ácido fórmico, presente em determinadas aguardentes consideracio por muitos autores como um produto normal da ferme'ntaçăo.

Os ácidos butírico, capróico, caprílico, pelargônico, etc., que aparecem nas aguardentes, originam-se sob a influencia enzimática de diversos micin-organismos ou pela açáo oxidante ao ar

$$
\begin{aligned}
& \mathrm{C} 6 \mathrm{H} 1206=2 \mathrm{C}^{3} \mathrm{H}^{603} \\
& \text { g'ucose ácido láctico } \\
& 2 \mathrm{C}^{3} \mathrm{H}^{603}=\mathrm{C}^{3} \mathrm{H}^{7} \cdot \mathrm{COOH}+2 \mathrm{CO}^{2}+2 \mathrm{H}^{2} \\
& \text { ácido butí } \\
& \text { r100 }
\end{aligned}
$$


Os esteres existentes nas aguardentes, provem da combinaçăo d'stes ácidos com o álcool ordinário ou com os outros alcoóls que também se produzem durante a fermentaçåo alcoblica.

$$
\begin{aligned}
& \mathrm{CH}^{3} \quad \mathrm{CH}^{3} \quad \mathrm{CH}^{3} \\
& \mathrm{CH}^{2} \mathrm{CH}+\mathrm{COOH}=\underset{\text { acetato de etilo }}{\mathrm{COO}}-\mathrm{CH}^{2}-\mathrm{CH}^{3}+\mathrm{HOH}
\end{aligned}
$$

Os h:mólogos superiores do álcool etilico, cuja presença se constata nas aguardentes, tem sua origem no metabolismo normal de a!buminas da levedura viva. Os alcools superiores isoamilit.o, amilico, iso-butilico, propilico, etc., formados por este processo de hidrolise das proteinas no interior das células da levedura, difundem-se juntamente com o álcool etilico através da membrana celular, no liquido exterior, que desta maneira deles se enriquece.

O: distirtos alcoóis homólogos superiores provém de amino-ácidos de constituiçáo perfeitamente determinada. Assim, a leucina produz o ślcool iso-amilico :

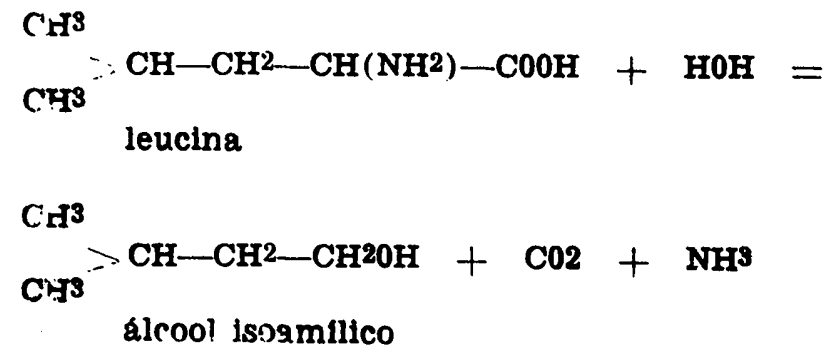

O álcool amilico ativo é proveniente da iso-leucina :

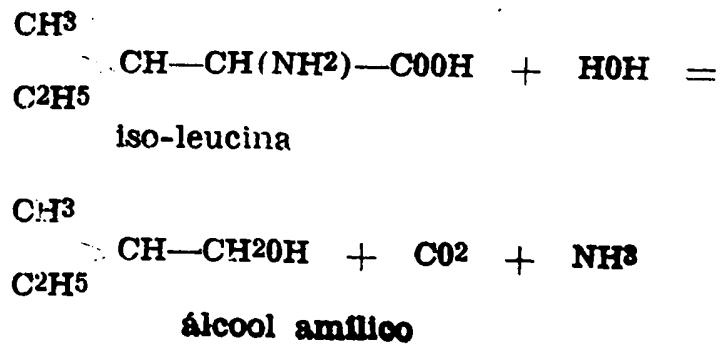


A vaina por adiçáo de água e separaçáo simultanea de amoniaco e anidrido carbonico, produz o álcool iso-butillico :

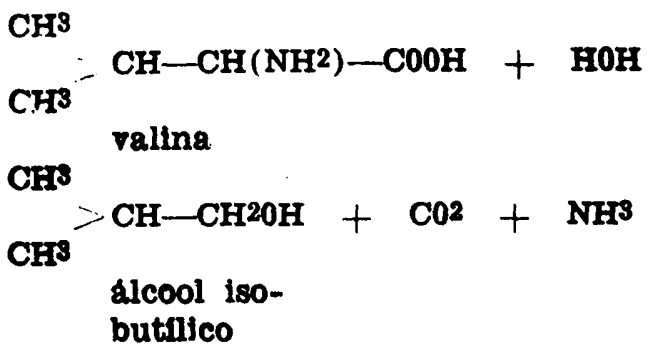

t provável que os outros alcoóis superiores se formem custa de outros amino-ácidos das protelnas. sobre a origem do álcool propillico normal, existem dúvidas ainda : năo se precisou si: ele deriva do ácido alfa amino-butírico, ou se provém do açúcar.

Trabalhos modernos nos mostram que na fermentaçăo alcoólica a órigem da glicerina, como produto normal e fixo, se verifjea por dupla decomposiçắo da glucose, de conformidade com as equaçoer seguintes :

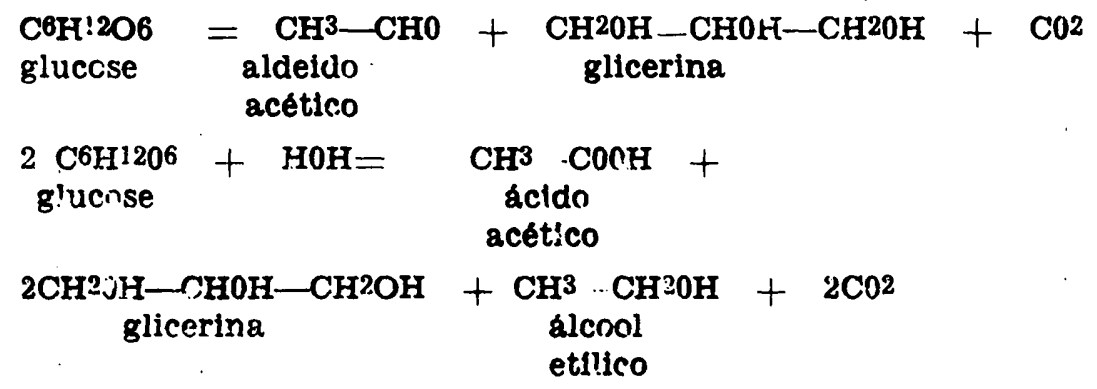

O furfurol ou aldeido piromúcico não se encontra em todas as aquardentes novas. He mais comum quando se distilam os vinhos, provenientes de cereais ou muito ricos de hidratos de cerbono. a fogo nú.

As bases nitrogenadas existem em todos os produtos alcoslicos. em quantidade multo variável. Elas provem, na maior parte da acidentes de fabricaçáo e encontram-se em mator quantida te nos mostos muito poluidos de microorganismos au quando as fermentaçð̄es săo muito impuras.

Pelo envelhecimento. em consequencia das multiplas e complexas reaçoes que se produzem entre estes diversos compone'zles das aguardentes, as suas qualidades organolépticas 
melhuram consideràvelmente : adquirem melhor aroma, cor de ouro "velho, sabor fino e suave. Como consequencia imediata resulta o extraotdinário acréscimo do valor comercial do produto.

Náo iratamos aqui senáo do envelhecimento natural das aguardentes, pois no comércio existem muitas pingas ditas velhas, que envelheceran a toque de fadas, mediante apenas a adição de caramelo... Raríssimas sấo de fato as que merecem ser chamadas velhas e estas, quando realmente 0 . šro, precisam ser vendidas por alto preço, porquanto o envelhecimento 6 uma operaçáo extremamente cara. $O$ comerciante esperto dos dias de hoie (perdoem a redundancia, por saber disso, é que transforma tóda sua pinga ordinária e recém-distilada em pinga velha $c \cdot m$ açúcar queimado, pimenta do reino, etc :......

As tentativas honestas que se tem feito para o envelhecimento artificial e rápido das aguardentes tem fracassado quase que por completo, comparativamente à qualidade da aguardente normalmente envelhecida. Náo é só por serem honestas que elas têm fracassado (?), mas principalmente porque até hoje năo se conhecem com detalhes as modificaçoes que se manifestam entre os componentes naturais das aguardentes, traduzidas pelo envelhecimento.

Sabe-se, com certeza, que há profunda alteração no grau alco6lico e no volume originais do produto, ao passo que se supóe, que pela influencia dos anos, porçбes minimas de produtos secun lárjos se formam, os quais somados aos ésteres principais também originados durante a conservaçăo, é que văo dar às aguardentes velhas, àquele conjunto de qualidades principescjs, que englobamos com o sugestivo nome de gosto redondo.

J́́ vai longe o número de anos que o professor ROCHA DE ALMEIDA prepara. cataloga e conserva amostras de aguardentes fabricadas na cadeira de Tecnologia da "Luiz de Queiroz", com o fim de estudar o assunto que encabeça o presente trabalho. Entretanto, por razóes independentes da sua vontade, a conservaçáo das amostras náo póde ser feita como devia, em vasilhame de madeira, com exceçáo da numero 4. Todas as demats foram: conservadas em litros arrolhados com rolha de cortiça nťo lavada e mantidos deitados sobre prateleiras :existentes no porăo do laboratório da 8.a cadeira daquela Escola.

A primeira investigação séria feita neste velho mostruário reveln? fatcis curiosos que vimos trazer à público, para julgamento daqueles que se interessam por trabalhos de pesquisa deste jaez.

A relacáo abaixo especifica a natureza dos produtos examinados pelos autores, bem como pre em evidencla o número de anos de rada amostra. 
QUADRO II

Protocolo das aguardentes examinadas

\begin{tabular}{|c|c|c|c|}
\hline$i_{0}^{0}$ & Natureza dss aguardentes examinadas & & $\begin{array}{l}\text { Idad } \\
\text { mese }\end{array}$ \\
\hline 3 & $\begin{array}{l}\text { Aguardente de cana } \\
\text { Aguardente de cana } \\
\text { Aguardente de cana } \\
\text { Aguardente de cana }\end{array}$ & & $\begin{array}{l}158 \\
157 \\
157 \\
157\end{array}$ \\
\hline 5 & $\begin{array}{l}\text { Aguardente de cana } \\
\text { Aguardente de cana } \\
\text { Aguardente de cana } \\
\text { Aguardente de caninha } \\
\text { Aguardente de pera } \\
\text { Aguardente de pera } \\
\text { Aguardente de pera } \\
\text { Aguardente de pera }\end{array}$ & $\begin{array}{l}10-4-1934 \\
9-6-1934 \\
8-9-1034 \\
2-9-1934 \\
1-5-1934 \\
2-5-1934 \\
9-5-1934 \\
8-6-1934\end{array}$ & $\begin{array}{l}151 \\
140 \\
146 \\
146 \\
150 \\
150 \\
150 \\
140\end{array}$ \\
\hline & $\begin{array}{l}\text { Aguardente de cana: variedade Co. } 312 \\
\text { Aguardente de cana: variadade POJ } 979 \\
\text { Aguardente de cana: variedades } 312 \text { e } 979 \\
\text { Aguardente de cana: variedade Co. } 281 \\
\text { Aguardente de cana: variedade POJ } 36 \\
\text { Aguardente de cana: variedade POJ } 2883 \\
\text { Aguardente de cana: variedade POJ } 2725 \\
\text { Aguardente de cana: variedade POJ } 2714 \\
\text { Aguardente de cana: variedade POJ } 2714 \mathrm{~V} \\
\text { Aguardente de cana: variedade Co. } 312 \\
\text { Aguardente de cana: variedade F } 4 \\
\text { Aguardente de cana: variedade POJ } 2878 \\
\text { Aguardente de cana: variedade POJ } 2878 \\
\text { Aguardente de cana: variedade POJ } 2878 \\
\text { Aguardente de cana: variedade POJ } 2878 \\
\text { Aguardente de cana: variedade POJ } 979 \\
\text { Aguardente de cana: variedade Co. } 313\end{array}$ & $\begin{array}{l}2-8-1936 \\
18-8-1936 \\
19-8-1936 \\
21-8-1936 \\
21-8-1936 \\
23-8-1936 \\
24-8-1936 \\
25-8-1936 \\
25-8-1936 \\
25-8-1936 \\
25-8-1936 \\
26-8-1936 \\
26-8-1936 \\
26-8-1936 \\
27-8-1936 \\
29-8-1936 \\
5-9-1936\end{array}$ & $\begin{array}{l}124 \\
124 \\
124 \\
124 \\
124 \\
124 \\
124 \\
124 \\
124 \\
124 \\
124 \\
124 . \\
124 \\
124 \\
124 \\
124 \\
123\end{array}$ \\
\hline & $\begin{array}{l}\text { Aguardente de cana } \\
\text { Aguardente de cana } \\
\text { Aguardente de cana } \\
\text { Aguardente de cana } \\
\text { Aguardente de cana } \\
\text { Aguardente de cana }\end{array}$ & & $\begin{array}{l}112 \\
112 \\
112 \\
112 \\
112 \\
112\end{array}$ \\
\hline & $\begin{array}{l}\text { Aguardente de cana com extrato de carvalho } \\
\text { Aguardenta de cana desodorisada e tratada } \\
\text { com sacarose e glicerina } \\
\text { Aguardente de cana desodorisada e tratada } \\
\text { com sacarose e glicerina }\end{array}$ & 4- 6-1945 & 17 \\
\hline & $\begin{array}{l}\text { Pinga de cana, sem tratamento } \\
\text { Pinga de cana, sem tratamento } \\
\text { Pinga n. } 40 \text {, depois de arejada e tratada } \\
\text { com glicertia } \\
\text { Pinga n. } 41 \text {, depois de novamente arejada } \\
\text { e tratada com sacarose } \\
\text { Aguardente } d \text { e banana }\end{array}$ & $\begin{array}{l}\text { Junho/1946 } \\
\text { Junho/1946 } \\
\text { Junho/1846 } \\
\text { Junho/1946 } \\
\text { Maio/1940 }\end{array}$ & $\begin{array}{l}6 \\
6 \\
6 \\
6\end{array}$ \\
\hline & lente a & & \\
\hline
\end{tabular}


Os elementos estudados pelos autores nas aguardentes aclma prolocolades foran os seguintes, que seráo examinados pela ordern :

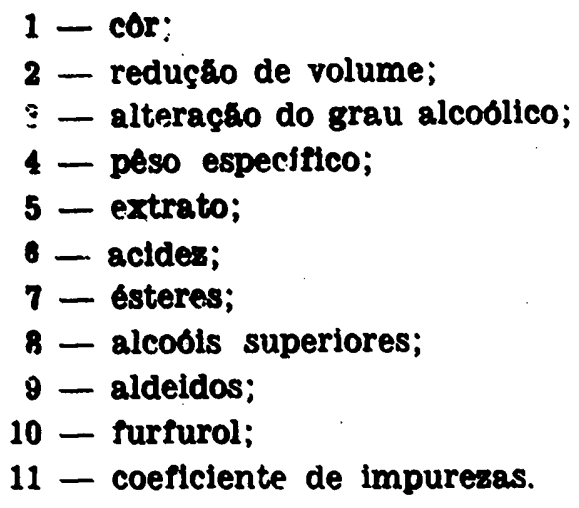

\section{1 - COR DAS AGUARDENTES}

Fola listlliçăo do vinho as aguardentes saem absolutamente incolores, e assim se manterzo indefinidamante se forem conservadns en recipientes de vidro com rolha esmerilhada, bem cheins. aue neste caso năo se passam entre os componentes das aguardentes os mesmos fenomenos de oxidaça e solubilizaç ${ }^{\star} 0$ de matérias extrativas que se verificam quando envelhecom am vasilhame de madeira ou tamponado con rollia de cortira.

Alíss, náo é obrigatória a mudança de côr para caracterizar uma aguardente velha. pois muitas há, até, que c cumércio exige seiam incolores. $\mathrm{t}$ o caso da grande maioria das aguardentes de frutas.

Nins reciplentes de vidro conseguem-se resultados mais ou menos identicos, porém menos intensos, aos obtidos nos de maceira, quando o seu tamponamento náo é felto com rolha de vidro : sim de cortiça. E que por ser esta muito rica em matérias extrativas e permévels ao ar, as trocas gasosas indispensiveis ans fencmenos inerentes ao envelhecimento se realizam com relativa facilidade e as materias solaveis extraidas colo- 


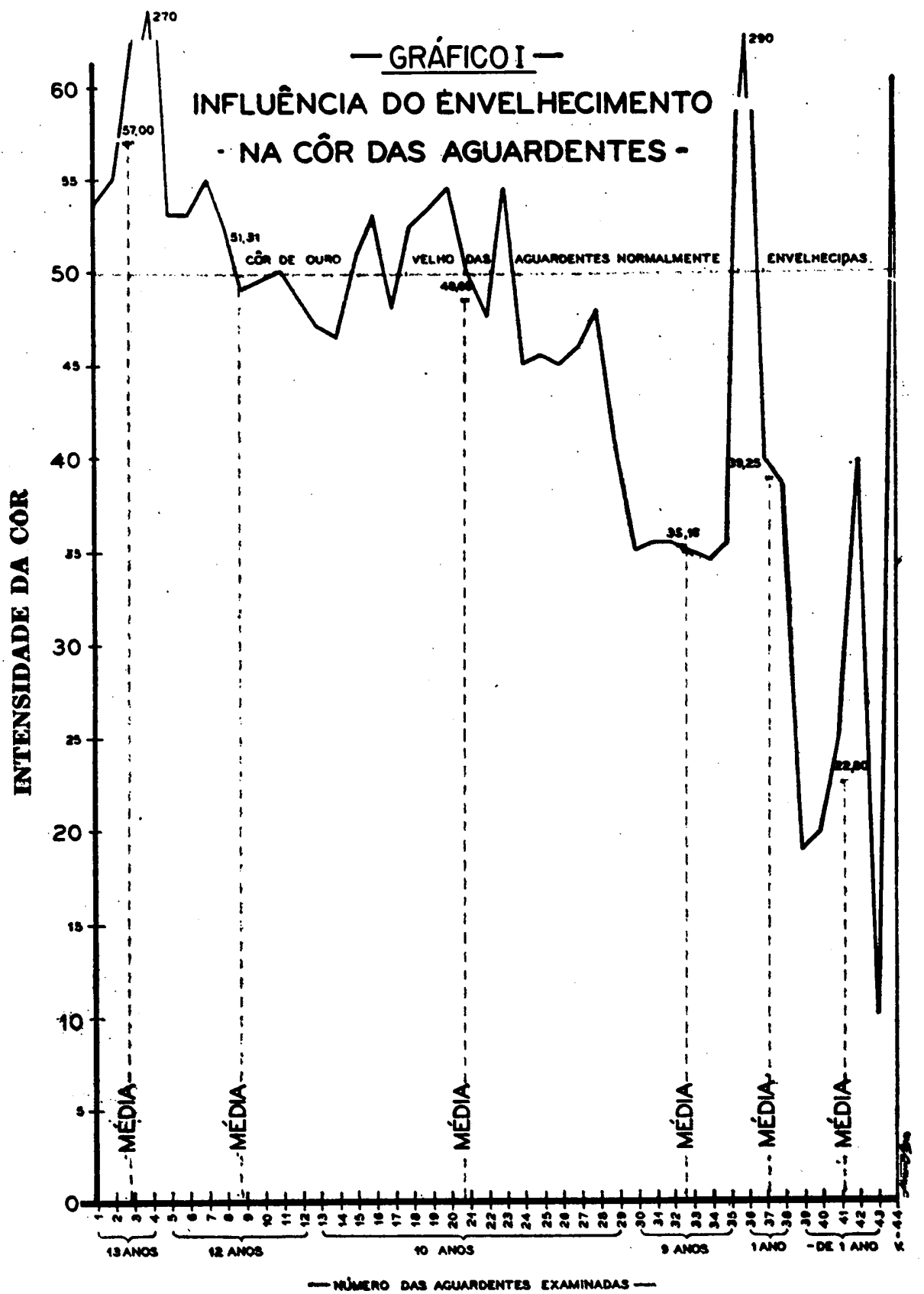


rem a aguardente, que adquire entåo a cor de ouro velho caracteristica.

Fervendo-so as rolhas em várias águas, até que o cozimento aquoso náo seja colorido; secando-as após resfriamento por imerşo em álcuol e parafinando-as antes do arrolhamento das garrajas, verifica-se que a cor da aguardente nelas conservada năo se altera. Dá-se o mesmo quando se conservam as aguardentes em toneis de madeira muito bem parafinados internamente e pintados externamente com cal à base de cola. $O$ envelhecinnento natural é então prejudicado em ambos os casos pela falta de oxigenio do ar, requerido nas reaçós de oxidaçăo, e roja carencia de matérias extraidas solubilizadas da madeira.

Como por via de regra, no comércio das bebidas alcoolicas se costuma julgar uma pinga velha primeiramente pela cor, é que s's originou o hábito de colorir a pinga nova, artificialmente com caramelo cu, entăo, pela adiçáo, dentro dos toneis, de pedaços de madeiras ricas em materias extrativas, com o fim dc satisfazer a exigencia do consumidor.

Sem cưvida alguma a madeira mais recomendável para o envelheciriento das aguardentes é o carvalho, que năo encontrou ainja substituto. As aguardentes conservadas nestes recipientes, pelo envelhecimento natural, adquirem uma cor caracte:istica e um aroma todo especial, muito suave. Os conhaques, por axemplo. precisam ser, obrigatoriamente, envelhecidos em risciplentes de carvalho.

Para medir a intensidade da cor das aguardentes ensaiadas, cervimo-nos do seguinte método analitico: preparámos com rarnmelo uma soluçáo padrão que melhor nos pareceu corresponder a cór de ouro velho, bem típica das aguardentes enve'hecidas naturalmente. Com este padrăo, que representa - n. 50 do gráfico I, organizámos uma escala de córes, em que cada amostra representava um padrăo numérico proporcional A. intensicade cia colork:çăo. Pudemos assim estabelecer a comparaçăo colorimétrica ponderal de todas as amostras examinades, cujo: resultado: resumimos no quadro abaixo e llustramos no. eratice I. 


\section{QUADRO III}

\section{Variagino da cor das acuardentes}

\begin{tabular}{|c|c|c|c|c|c|}
\hline $\begin{array}{c}\text { Ntmore da } \\
\text { amoetra }\end{array}$ & $\begin{array}{l}\text { Intensidade } \\
\text { de our }\end{array}$ & $\begin{array}{c}\text { Netmere de } \\
\text { secetra }\end{array}$ & $\begin{array}{l}\text { Intensidade } \\
\text { da obr }\end{array}$ & $\begin{array}{l}\text { Namero in } \\
\text { amputra }\end{array}$ & $\begin{array}{l}\text { Intonaidade } \\
\text { da obr }\end{array}$ \\
\hline $\begin{array}{c}1 \\
2 \\
3 \\
4 \\
\text { Média } \\
5 \\
6 \\
7 \\
8 \\
9 \\
10 \\
11 \\
12 \\
\text { Media }\end{array}$ & $\begin{array}{r}58,5 \\
55,0 \\
62,5 \\
270,0 \\
57,00 \\
58,0 \\
53,0 \\
35,0 \\
52,5 \\
49,0 \\
49,5 \\
50,0 \\
48,5 \\
51,31\end{array}$ & $\begin{array}{c}18 \\
14 \\
15 \\
16 \\
17 \\
18 \\
10 \\
20 \\
21 \\
22 \\
23 \\
24 \\
23 \\
26 \\
27 \\
28 \\
20 \\
\text { Média }\end{array}$ & $\begin{array}{c}47,0 \\
46,5 \\
30,5 \\
53,0 \\
48,0 \\
32,5 \\
53,5 \\
54,5 \\
50,0 \\
47,5 \\
54,5 \\
45,0 \\
45,5 \\
45,0 \\
40,00 \\
48,0 \\
40,5 \\
48,66\end{array}$ & $\begin{array}{c}30 \\
31 \\
32 \\
33 \\
34 \\
35 \\
\text { Média } \\
30 \\
37 \\
38 \\
\text { Média } \\
39 \\
40 \\
41 \\
48 \\
48 \\
\text { Média } \\
44\end{array}$ & $\begin{array}{c}36,0 \\
36,5 \\
36,5 \\
35,0 \\
34,5 \\
35,5 \\
36,16 \\
\\
240,0 \\
40,0 \\
30,5 \\
30,26 \\
19,0 \\
20,0 \\
25,0 \\
40,0 \\
10,0 \\
22,8 \\
\mathbf{c 0 , 5}\end{array}$ \\
\hline
\end{tabular}

clusoes :

Pelo exame destes dados podemos tirar as seguintes con-

1 - a cór, por si só, náo serve como critério seguro para julzamento da idade de uma aguardente;

2 - peln envelhecimento as aguardentes sempre adquirem certa coloraşa, desde que o vasillhame usado seja apropriado; is cuja intensidade é variável com o tempo de conservaç?o e crim a natureza do vasilhame utilizado;

3 - "esultados iguais ou mais intensos se conseguem pela ad"clio je extrato de carvalho a aguardente recentemente distilada.

A primeira conclusáo é evidente. Para julgar do seu acerto, basta ver crimo sto dispares os resultados apresentados pe- 
las amostras das aguardentes examinadas. Amostra com 12 anos, como a número 7; com 10 anos, como as de número 20 e 23, apresentam-se mais coloridas que a amostra 1 de 13 anos. Mals hucante é o resultado da amostra 42, que com 1 ano é mais colorida que todas as amostras de 9 anos. Igualmente é intercssante o exame das aguardentes de números 13 e 29, que com 10 anos df idade, se apresentam muito diversamente coloridas.

Pelo exame dos resultados que ora apresentamos, abre-se mais um campo aos estudiosos com a pergunta - Terá a varledare de cana alguma influencia sóbre a coloraçáo da aguardenti envelhecida? Pelo que mostra o nosso gráfico, parece que sim. Isto é, que a coloraçáo adquirida pelas aguardentes depois re certo tempo de conservaçáo é também uma queståo varieta! Resta pesquisar esse fato. Aliás, é de se supor que o fato seja yerdzdeiro. uma vez que na fabricaçáo da aguardente, a questão da variedade de cana, tem notavel influencia. Nos nossos estudos realizados anualmente na "Luiz de Queiroz" em Piracic nba, estamos cansados de verificar tal fato, náo só em relaçăo à facilidade da fermentaçáo, como na resistencla do pé de Permentação, bem como no rendimento e na qualidade da aguardente proriuzida. Assim, a CP 27/139 e a POJ 2727, sấo indiscutivelmente muito superiores à Co. 290, neste particular. Todo fabi icante de aguardente sabe bem das dificuldades que a fermentação do caldo da Co 290 acarreta quase todos os anos.

Todas as aguardentes adquirem maior ou menor intensidade de cór pelo envelhecimento. Pode-se dizer, sem medo de errar que se se fizer a conservaçăo das aguardentes em recipientes próprins, de madeira, não parafinados, elas tornar-se-ăo coloritas mais ou menos intensamente depois de certo tempo de envelhecimento, tendendo à côr ouro velho. Nestas condiçбes. a intensidade da coloração vai depender estreitamente da natureza de madeira de que é feito o vasilhame e das condị̧os de armazenamento.

Eliminando-se os extremos apresentados pelas amostras a e 36. - tomando-se a média por idade de conservaçáo, verifica-se o acerto da nussa segunda conclusáo. De fato, verifica-se que com :

13 anns a intensidade é de $\ldots \ldots \ldots \ldots \ldots \ldots \ldots$ 57,00;

12 anos a intensidade é de $\ldots \ldots \ldots \ldots \ldots \ldots \ldots . \ldots 51,31 ;$

10 anns $a$ intensidade é de $\ldots \ldots \ldots \ldots \ldots \ldots$ 48,66;

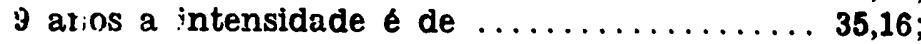

1 aro a intensidade $e ́$ de $\ldots \ldots \ldots \ldots \ldots \ldots 39,25$

menos de 1 ano a intensidade de $\ldots \ldots \ldots \ldots 22,80$. 
Os dacios mostram evidentemente que à medida que a aguardente envelhece ela se torna mais colorida. A aparente contradiç̧̌o no caso das aguardentes de 1 ano, reside no fato de que as amostras 37 e 38 foram edulcoradas, o mesmo se dando $\mathrm{ccm}$ as amostras 41 e 42.

Que a intensidade da cór é influenciada pelo sistema de cons?"vaçao e pelo tratamento artificial a que se submeter a aguarierte. nác resta a menor dúvida. bastante observar as duas amostras 4 e 42 intensamente coloridas. A primeira foi conservada durante 13 anos em barril de madeira e a segunda foi tratada com. extrato de carvalho, razão porque, apesar de ser esta ultima incomparàvelmente mais nova, acusa uma intensidade de coloraçăo extraordinariamente mais alta. $O$ mesmo se verifica $\mathrm{cnm}$ as amostras $37,38,41$ e 42 que foram adicionada. de certa quantidade de açucar e de glicerina.

\section{2 - REDUÇAO DO VOLUME}

'I'idns as fenómenos de envelhecimento das aguardentes săo acompanhados pela diminuiçáo do seu volume, que se dá de maneira contínua e lenta.

Naturalmerte, a maior ou menor rapidez desta diminulçáo do volume ou intensidade de evaporaçăo está diretamente condinionada à natureza do vasilhame usado na conservaçáo da aguardente.

Se for feita em vasilhame do vidro, com rolha esmerilhada, naturalmente o volume manter-se-á indefinidamente inalterado, pais nóo há perdas por evaporaçáo.

Se de vidrn, com rolha de cortiça, a diminuiçăo do volume por evapnraçă se fará com maior ou menor intensidade de acorco $\mathrm{crm}$ a porosidade da rolha, diametro do gargalo, temperatura e umidade do ambiente em que săo conservados os recipientes.

Nos reciplentes de madeira, a diminuiçác do volume é mais regular, dependendo natural e logicamente de inúmeras causas, gue aliás săo causas comuns a todo vasilhame :

1 - porosidade do vasilhame; 
2 - capacidade, forma, perfeiçăo da construçăo e estado de conservacáo;

3 - temperatura, estado higrométrico e condiçóes de ventilaçăo.

bom que se trise novamente que a porasidade da madelra é 'm? cond'çăo indispensável para se conseguir bons resultadó na operaca de envelhecimento, pois e justamente por meio dela que se verifica a entrada do ar exterior para o interior do recip'ente e a saida do liquido interno para o extericr através da madeira.

Nicm todas as madeiras se prestam para esse mister, sendo ainda o carvalho a que oferece as melhores condiçoes de porosidare, desde que seja convenientemente escolhida e de especie apropriada, pois tambem nem todo o carvalho se presta para tal fim.

Justamente por ser a madeira de capital importancia nn enve! hecimento das aguardentes e, por ser impraticável o uso do carvalho no nosso pals, é que resolvemos verificar se alguma das especies de essencias florestals, indigenas ou exotticas existentes no Brasll, oferece as condiçóes necessárias para : fabricaç. de vasilhame para a conservaça de aguardente Intcińmos já as nossas observaçóes com a araruva e o amendolm.

Ecrolhida a madeira, ela precisa ser selecionada, aprove:tando-se apenas as tábuas mais perfeltas, sem furos, brocas or rachaduras de textura compacta $\epsilon$ bem grossa, condiçoes essas bem diferentes das exigidas para a construçáo de vasilhame destir ado 8.0 transporte. Naturalmente quanto mais fina. e poross:- forem as aduelas, mais ativo será o fenomeno fisico da evaporaçáo do álcool e da água e das trocas gaso-

No vasilhame de pequena capacidade o envelhecimento é muitr. mais rápido que no de grande capacidade, pois o pri-

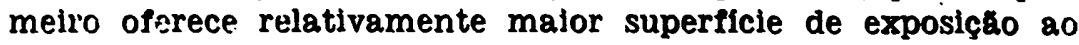
ar. Arsim :endo, quando menor for o volume do vasilhame mais ativa será a oxidaçăo por isso que se dá preferencia no envelheilmento das aguardentes finas, como os conhaques, aos barri: de madnira de capacidade variando de 100 a 500 litros. mantifos separadamente uns dos outros, dentro do deposita. cujo piso deve estar ao nivel do solo. A mesma razbo determina a prefurencia da escolha da forma do vasilhame. 
O reciplente, dadas as condiçóes do liquido em envelhecimento, precisa ier muito bem construido, com muito maior numero de aros externos de ferro e mantido muito bem conservado. Caso contrário, a açáo desidratante do álcool pode provocar o ressecamento das aduelas, ocasionando evaporaçáo excessiva e ate mesmo vasamento pelas fendas que se formarem.

Quando novas os barris precisam ser tratados convenientemente antes de colocar o produto a conservar, pois a madeira nova cede a aguardente produtos extrativos os mais variados, itentre os quais predomina o tanino e materias afins, bem como substancias sápidas intermediárias. Estas substancias quando em excesso dáo gôsto extranho e grande quantidade de extrato ac procuto, depreciando-o. O melhor tratamento prelimirisr dos barris consiste em passar vapor internamente sob press5.o ou lavar repetidas vezes com água fervendo, até que o condensado ou as águas de lavagem náo saiam coloridas e náo tenham gôsto adstringente. Dá ótimos resultados também, o emprógo de água quente acidulada com 5 a $10 \%$ de ácido sulfúrico que é deixada no barril durante 24 horas. Escoada, lava-se o rạcipiente várias vezes com água quente e depois com água fria.

O) local ou depósito para o armazenamento dos recipientes que contêm aguardente para envelhecer, náo deve ser muito seco e vertilado, mas apresentar uma temperatura e um estado h'grométrico favoráveis ao envelhecimento, sem facilitar o desenvolvimento de bolores, e, ademais, permitir seja a ventilaçăo controlável.

Vaturalmente, quando todas as condiçós acima mencionadais se harmonizam de modo a facilitar a evaporaçáo, a diminuiñáo do volume da aguardente durante o envelhecimento será máxima. A reciproca também é verdadeira, sendo que neste casn as condiçбes såo impróprias ao envelhecimento, pois contrarian as oxidaçoes. Cabe ao técnico equilibrar as condiçб́es de armazenamento para tirar delas o malor proveito possivel.

A determiraçăo da reduçăo do volume das aguardentes examinadas foi feita por mediçáo direta, obtendo-se os seguintes daros, que serviram para a construçăo do graflco $I I$. 


\section{QUADRO IV}

Reduglio do volume das aguardentes

\begin{tabular}{|c|c|c|c|c|c|}
\hline 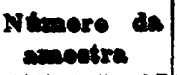 & $\begin{array}{c}\text { redugle do } \\
\text { rolume } \%\end{array}$ & $\begin{array}{l}\text { Nemore da } \\
\text { amonten }\end{array}$ & $\begin{array}{l}\text { Reduglo do } \\
\text { rolnges } x\end{array}$ & $\begin{array}{c}\text { Nenore do } \\
\text { amoutra }\end{array}$ & $\begin{array}{l}\text { redugto os o } \\
\text { relume } \%\end{array}$ \\
\hline $\begin{array}{c}1 \\
2 \\
8 \\
4 \\
\text { Media } \\
5 \\
6 \\
7 \\
8 \\
9 \\
10 \\
11 \\
12 \\
\text { Media }\end{array}$ & $\begin{array}{c}19,6 \\
19,9 \\
29,5 \\
38,0 \\
18,66 \\
\\
9,4 \\
10,2 \\
9,6 \\
12,6 \\
11,5 \\
29,7 \\
30,2 \\
15,6 \\
16,10\end{array}$ & $\begin{array}{l}13 \\
14 \\
15 \\
16 \\
17 \\
18 \\
19 \\
20 \\
21 \\
29 \\
23 \\
24 \\
25 \\
26 \\
27 \\
28 \\
20 \\
\end{array}$ & $\begin{array}{r}8,0 \\
0,9 \\
7,6 \\
11,0 \\
12,4 \\
32,0 \\
12,8 \\
13.0 \\
8,2 \\
7,5 \\
11.7 \\
8,3 \\
3.5 \\
9,0 \\
8.5 \\
7,8 \\
7,8 \\
9,81\end{array}$ & $\begin{array}{c}90 \\
31 \\
32 \\
39 \\
34 \\
38 \\
\text { Médie } \\
36 \\
37 \\
38 \\
\text { Média } \\
39 \\
40 \\
41 \\
42 \\
43 \\
\text { Média } \\
4 \\
4\end{array}$ & $\begin{array}{l}7.0 \\
6,7 \\
6,1 \\
3,0 \\
4,3 \\
6,0 \\
6,05 \\
1,1 \\
1, .3 \\
1,2 \\
1,23 \\
0.1 \\
0,1 \\
0,2 \\
01 \\
0.2 \\
0.14 \\
30,8\end{array}$ \\
\hline
\end{tabular}

Comn se prode verificar, a diminulçăo do volume fol relativamente pequena, porquanto as amostras nio foram conservadas em barris e sim em litros arrolhados com rolhas de cortiça mantidos horlzontalmente no poráo do laboratorio de Tecnologia, onfe a temperatura raramente ultrapassa de $20^{\circ} \mathrm{C}$. Mesmo assim, as medias revelam claramente que a medida que os anos caminham a reduçác do volume năo estaciona. H o que acusa'n na dados abaixo:

IHad: em anos

Reduçáo do volume\%

$\begin{array}{rr}13 & 18,66 \\ 12 & 16,10 \\ 10 & 8,91 \\ 9 & 6,05 \\ 1 & 1,28 \\ \text { menos de } 1 & 0,14\end{array}$


Non ćilculo da méciia das-aguardentes de 13 anos năo computámos a amostra 4 que foi conservada em barril de madeira.

Em alsumas mostras, como as de número $3,10.11,17$, 18 e 20. provàvelmente devido ao uso de rolhas mais porosas, a perda foi mais sensivel, ultrapassando a média geral de cada série.: Rạôes crntrárias, determinaram nas amostras 1, 5, . . 14 e 34 uma diminuiçăo de volume muito inferior à médiă. Pelos dados obtidos pode-se admitir uma perda média de volume oscilardo no redor de 1 a 1,5\%, anualmente, quando a cunservaçáo sẹ faz em litros, sendo cêrca de 5 vezes maior quando a conservaçáo se faz em barris de madeira.

A mijor perda se verificou na amostra 4, conservada em barrii de 100 litros, onde a diminuição do volume atingiu a $58 \%$. apesar de mantida nas mesmas condiçסes outras das demais amostras A causa desta maior evaporação reside na maior superficio de expcsiçáo ao ar em relaçáo aos litros e à porosidacle da madeira.

Scta diminuição do volume que sempre se verifica na prática, pcì: aquí nunca se faz conservaçăo em reciplentes de vidro e sim em toneis de madeira, é uma das causas mais ponderáveis que justificam plenamente a elevada majoraçáo que sofre o preço das pingas realmente velhas.

\section{3 - ALTERAÇÃO DO GRAU ALCOOLICO}

Pela evaporaçăo da água e do álcool origina-se" uma diminuição do volume da aguardente contida nos recipientes de envelhecimento, enquanto que a graduação alcoblica é profun... damente afetaria.

() álcnol e a água não se evaporam com a mesma intensidade ou na mesma proporçáo. O fenômono da reduçáo do grau alcoólico experimentado pelas aguardentes em conservação se tornfi. bem compreensivel se atendermos que a aguardente é uma nistura ridroalcoólica, cuja graduaçăo sempre levamos até $55^{\circ} \mathrm{G}$. L. Sendo o álcool muito mais volátil do que a água, é natur al ạe:êle se evapore em primeiro lugar. devido a esta perda de álcon! por evaporação através das paredes dos recipientce cue $a$ aguardente, à medida que vai. envelhecendo, se torna cala: vez mais fraca. Naturalmente isso vai depender estreitamente das condiçð̃es do ambiente onde se depositam os tonei's prra envelhecimento, se úmido ou seco. 


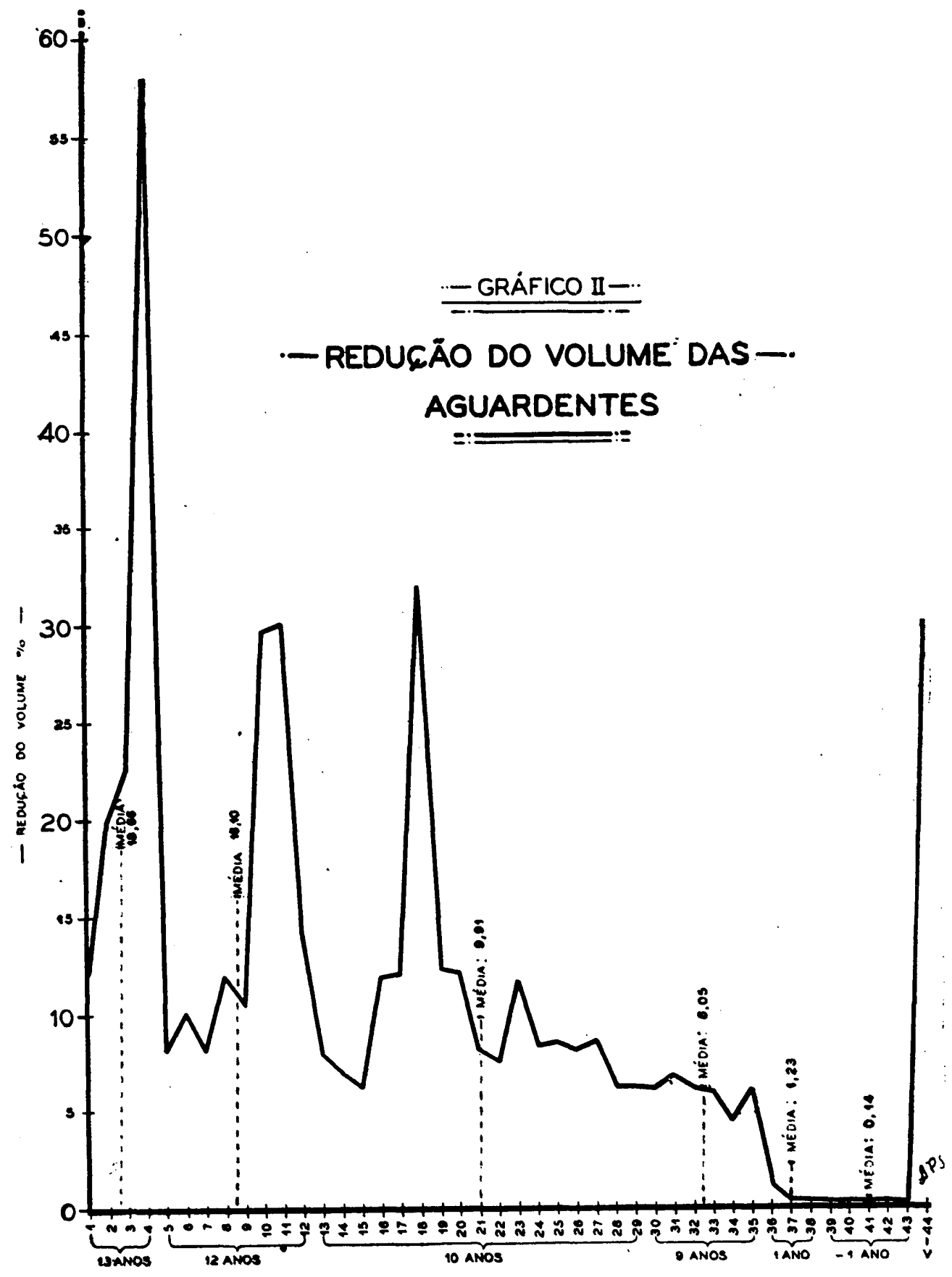

NOMER() DAS ACUARDENTES EXAMINADAS ....... 
Não quer isto dizer que uma pinga velha de otima qualida de sifa zquesa que tem uma graduação alcoólica mínima. Pelo contrário. todos os esforços do fabricante devem ser conduzidos de tal mcdo a evitar que a reduçáo do grau alcoblico ultrapısse certo :Imite, que podemos fixar nas vizinhanças de $40^{\circ} \mathrm{C}: \mathrm{T}$. que, ultrapassando este limite pelo envelhecimento exagersdo, a agıardente perde o sabor suave que adquiriu, aos paucos, durante longos anos. Isto seria uma perda irreparável pois o sabor constitui, sem dúvida, o caráter organoléptico de maior importancia para a cotaçáo comercial da bebida. Ao perder o que nós chamamos de "gosto redondo", a aguardente super-envelhecida se torna insiplda ou passada, podir $r$. do chegar, em casos extremos, a se transformar numa soluçño aquesa coloridn. Dal a razăo de aconselharmos, para as aguardentes que vão ser submetidas ao envelhecimento, uma graduaçån alcoólica inicial de $55-60^{\circ} \mathrm{G}$. L., pois nestas condiçбes, mesm!n com um envelhecimento demorado, năo se tornaråo insipidas.

A maior ou menor reduçáo do grau alcoblico está diretamente subordiriada às condiçóes que determinam a redução maior ou menor do volume da aguardente. Controlando-se er tas de maneira conveniente, regularizam-se aquelas de maneira satisfatoria.

No presente estudo, consideramos como ponto de partida, para mainr facilidade de comparaçáo, que tôdas as amostras forarin postas a envelhecer com $55^{\circ} \mathrm{G}$. L., o que equivale a uma densitade de 0,92953 a $15^{\circ} \mathrm{C}$. Na realidade isso năo é bem a expressão da verdade, pois nem sempre fol tomada a precauçăo acima com rigor, fazendo-se apenas a correçáo da temperatura na le!tura acusada pelo alcoômetro, sem corrigir a graduaçãn a coólica posteriomente com "cabeceira" ou água fraca, quáanjo esta graduação acusava apenas uma leve diferença para menos ou para mais. No entanto, assim admitimos porque essa rempre foi a nossa norma de distilar e, o nosso escopo é apenas mostrar que de fato há queda no grau alcoolico das aguoritentes durante o envelhecimento.

O metodo analítico seguido na determinação da graduação alcoólica fo! o da.distilaçăo de $100 \mathrm{cc}$. de aguardente, em Cl jo distilado, depois de resfriado, foi determinada a densidade de: $1^{\circ} \mathrm{C}$ com a balança Mohr-Westphal (Fig. 1). Por melo da Tabela I obtivemos a correspondencia entre a densidade e o grau alcoólico, expresso em volume e em peso. 


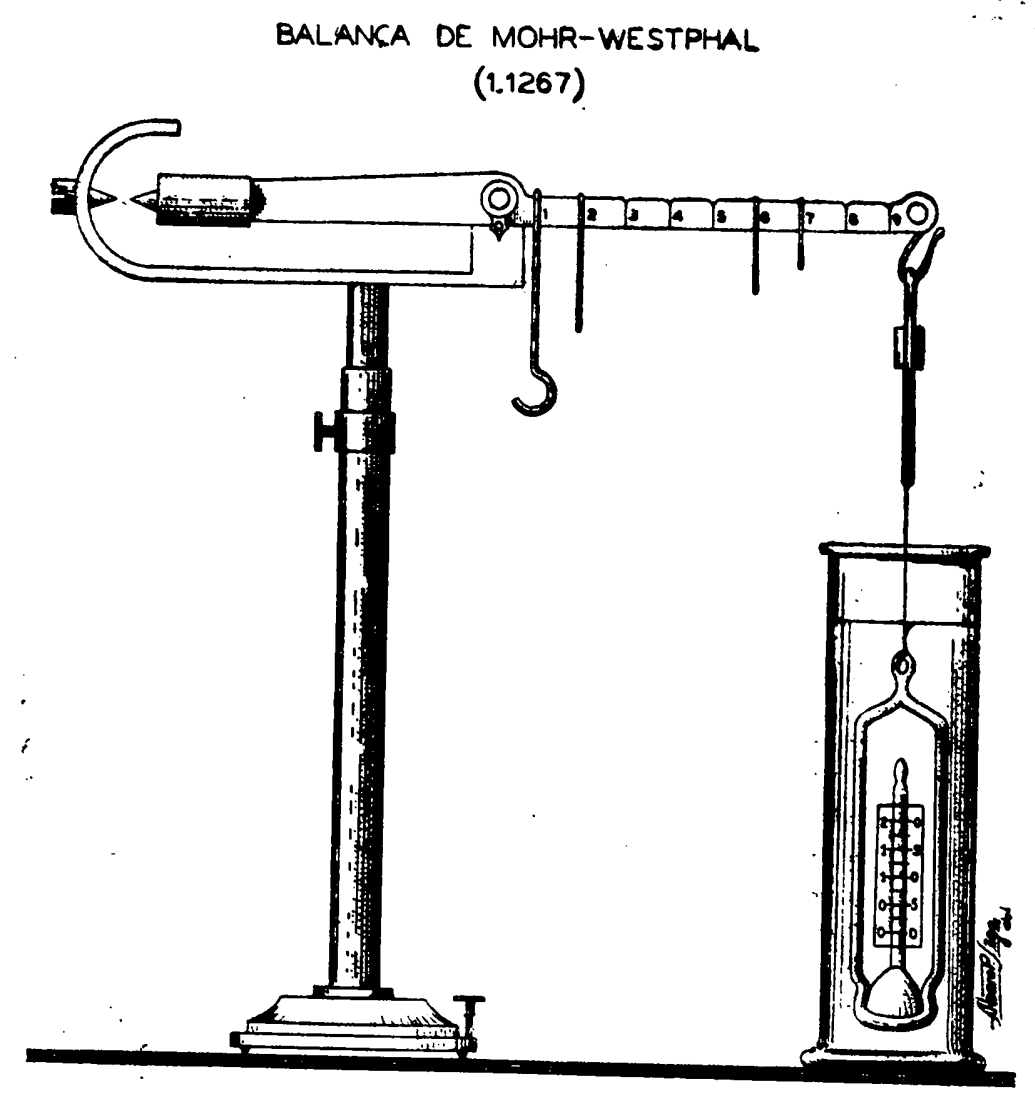

Fig. 1 
TABHA I

Tabela de pesos especificos a $15^{\circ} / 1^{\circ} \mathrm{C}$ e suas correspondéntes percentagens de álcool em pêso e em volume à temperatura de $15^{\circ}$ Centígrados

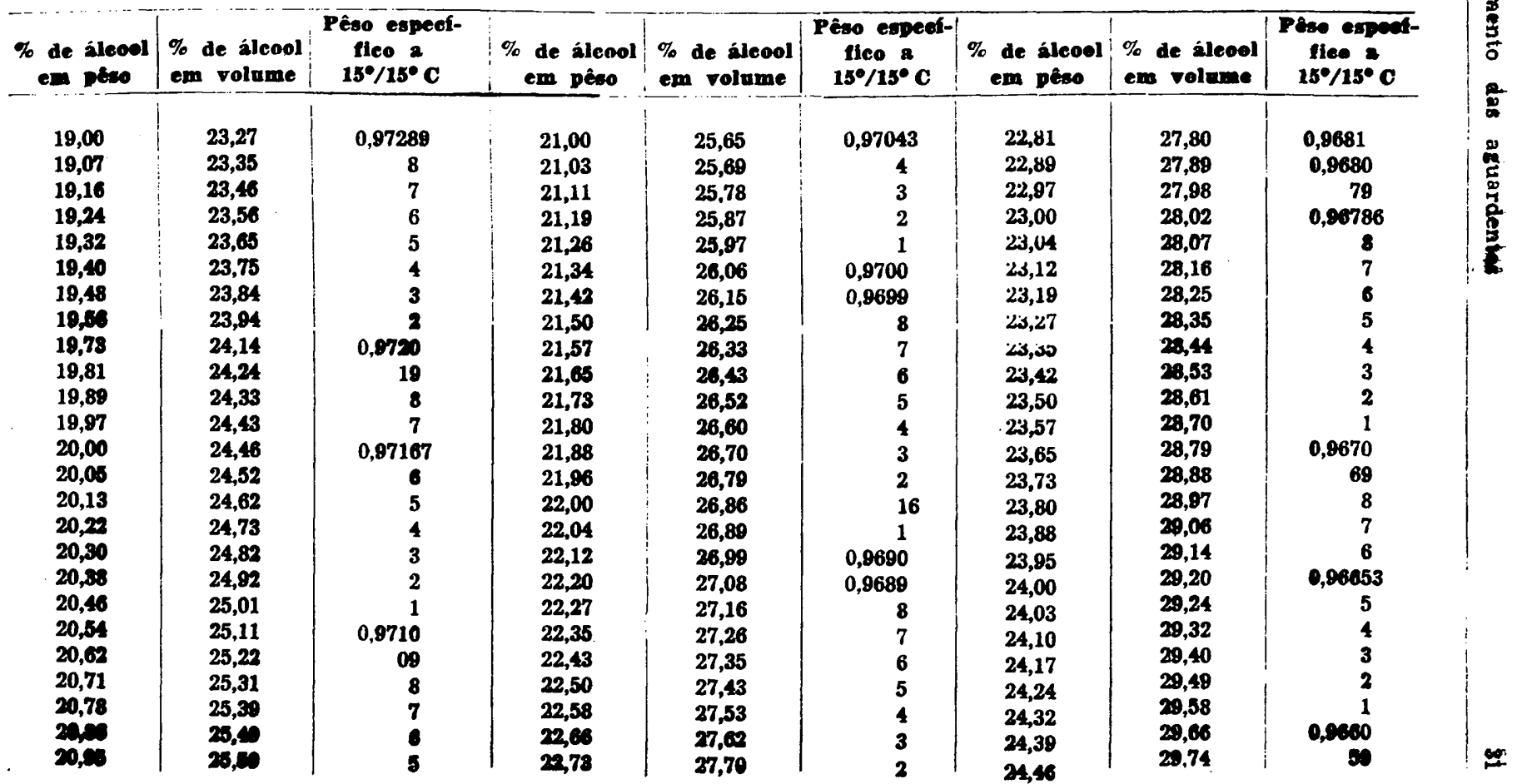


TABELA I (Continuação)

\begin{tabular}{|c|c|c|c|c|c|c|c|c|}
\hline $\begin{array}{c}\text { \% délcólcool } \\
\text { em pêso }\end{array}$ & $\begin{array}{l}\% \text { de álcool } \\
\text { em volume }\end{array}$ & $\begin{array}{l}\text { Pêso espect.- } \\
\text { fico a } \\
15^{\circ} / 15^{\circ} \mathbf{C}\end{array}$ & $\begin{array}{l}\text { \% de alcool } \\
\text { em peso }\end{array}$ & $\begin{array}{l}\% \text { de álcool } \\
\text { em volume }\end{array}$ & $\begin{array}{c}\text { Pêso especi- } \\
\text { fico a } \\
15^{\circ} / 15^{\circ} \mathrm{C}\end{array}$ & $\begin{array}{c}\because c \text { de áleool } \\
\text { em pêso }\end{array}$ & $\begin{array}{l}\text { cr de álcsol } \\
\text { em volume }\end{array}$ & $\begin{array}{c}\text { Pêso espeeí- } \\
\text { fico an } \\
15^{\circ} / 15^{\circ} \mathrm{C}\end{array}$ \\
\hline 24,53 & 29,82 & 8 & 26,47 & 32,09 & 1 & 28.30 & 34,22 & 4 \\
\hline 24,60 & 29.91 & 7 & 26,54 & 32,18 & 0,9630 & 28,36 & 34,29 & 3 \\
\hline 24,68 & 30,00 & 6 & 26.61 & 32.26 & 29 & 28,43 & 34.37 & 2 \\
\hline 24,75 & 30,08 & 5 & 26,68 & 32,34 & 8 & 28,49 & 34,44 & 1 \\
\hline 24,82 & 30,16 & 4 & 26,75 & 32.42 & 7 & 28,56 & 34,52 & 0.9600 \\
\hline 24,89 & 30,25 & 3 & 26,82 & 32,50 & 6 & 28,63 & 34,60 & 0,9599 \\
\hline 24,97 & 30,34 & 2 & 26,89 & 32,58 & 5 & 28,69 & 34,67 & 8 \\
\hline 25,00 & 30.37 & 0,96517 & 26,96 & 32,66 & 4 & 28,76 & 34,75 & 7 \\
\hline 25,04 & 30.42 & 1 & 27,00 & 32,71 & 0,96233 & 28,82 & 34,81 & 6 \\
\hline 25,11 & 30,50 & 0.9650 & 27,02 & 32,73 & 3 & 28,89 & 34,89 & 5 \\
\hline 25,18 & 30,58 & 0.9649 & 27,09 & 32.82 & 2 & 28,96 & 34,98 & 4 \\
\hline 25,25 & 30,66 & 8 & 27,16 & 32.90 & 1 & 29,00 & 35,03 & 32 \\
\hline 25,32 & 30,75 & 7 & 27,23 & 32,98 & 0,9620 & 29,02 & 35,05 & 3 \\
\hline 25,39 & 30,83 & 6 & 27,29 & 33,05 & 19 & 29,09 & 35,13 & 2 \\
\hline 25,46 & 30,91 & 5 & 27,36 & 33,13 & 8 & 29,15 & 35,20 & 1 \\
\hline 25,54 & 31,00 & 4 & 27,43 & 33,21 & 7 & 29,21 & 35,27 & 0,9590 \\
\hline 25,61 & 31,09 & 3 & 27,50 & 33,29 & 6 & 29,28 & 35,34 & 0,9589 \\
\hline 25,68 & 31,17 & 2 & 27,57 & 33,37 & 5 & 29,34 & 35,41 & 0,9588 \\
\hline 25,75 & 31,25 & 1 & 27,63 & 33,44 & 4 & 29,40 & 35,48 & 7 \\
\hline 25,82 & 31,34 & 0,9640 . & 27,70 & 33,52 & 3 & 29,47 & 35,56 & 6 \\
\hline $\mathbf{2 5 , 8 9}$ & 31,42 & 0.9639 & 27,77 & 33,60 & $?$ & 29,53 & 35,63 & 5 \\
\hline 25,97 & 31,51 & 8 & 27,84 & 33,68 & 1 & 29,59 & 35,70 & 4 \\
\hline 26,00 & 31,54 & 77 & 27,91 & 33,76 & 0,9610 & 29,66 & 35,78 & 3 \\
\hline 26,04 & 31,59 & 7 & 27,97 & 33,83 & 09 & 29,72 & 35,86 & 2 \\
\hline 26,11 & 31,67 & 6 & 28,00 & $\mathbf{3 3 , 8 7}$ & 0,96085 & 29,78 & 35,92 & 1 \\
\hline 26,18 & 31.76 & 0.9635 & 28,03 & 33,90 & 8 & 29,85 & 36.00 & 0,9580 \\
\hline 26,25 & 31,84 & 4 & 28,10 & 33,98 & 7 & 29,91 & 36.07 & 0.9579 \\
\hline 26,32 & 31,92 & 3 & 28,16 & 34,05 & 6 & 29,97 & 36,14 & 8. \\
\hline 26.39 & 32.00 & 2 & 28,23 & 34,14 & 5 & 30.00 & 36.17 & 75 \\
\hline
\end{tabular}


TABELA I (Continuação)

\begin{tabular}{|c|c|c|c|c|c|c|c|c|}
\hline $\begin{array}{c}\text { \%e de álcool } \\
\text { em pâso }\end{array}$ & $\begin{array}{l}\% \text { de álcool } \\
\text { em volume }\end{array}$ & $\begin{array}{l}\text { Pêso especi- } \\
\text { fico a } \\
15^{\circ} / 15^{\circ} \mathrm{C}\end{array}$ & $\begin{array}{c}\text { \% de álcool } \\
\text { em pêso }\end{array}$ & $\begin{array}{l}\% \text { de alcool } \\
\mathrm{em} \text { volume }\end{array}$ & $\begin{array}{c}\text { Pêso especi- } \\
\text { floo } \\
15^{\circ} / 15^{\circ} \mathrm{C}\end{array}$ & $\begin{array}{c}\text { \% de áleool } \\
\text { em pêso }\end{array}$ & $\begin{array}{l}\% \text { de álcool } \\
\text { em volume }\end{array}$ & $\begin{array}{c}\text { Pêso espoof- } \\
\text { fleo } \\
15^{\circ} / 15^{\circ} \mathrm{C}\end{array}$ \\
\hline 30,03 & 36,21 & 7 & $\overline{31,75}$ & 38,17 & 0.9549 & 33,34 & 39,97 & 2 \\
\hline 30,09 & 36.28 & 6 & 31,81 & 38,24 & 8 & $\mathbf{3 3 , 4 0}$ & 40,04 & 1 \\
\hline 30,16 & 36.36 & 5 & 31,87 & 38,30 & 7 & 33,46 & 40,10 & 0,9520 \\
\hline 30,22 & 36,42 & 4 & 31,93 & 38,37 & 6 & 33,51 & 40,16 & 0.9519 \\
\hline 30,28 & 36,49 & 3 & 31,99 & 38,44 & 5 & 33,57 & 40,23 & 8 \\
\hline 30,34 & 36,56 & 2 & 32,00 & 38.45 & 49 & 33,63 & 40,30 & 7 \\
\hline 30,40 & 36,63 & 1 & 32,05 & 38,51 & 4 & 33,69 & 40,36 & 6 \\
\hline 30,47 & 36,71 & 0,9570 & 32,11 & 38,58 & 3 & 33,74 & 40,41 & 5 \\
\hline 30,54 & 36.79 & 0,9569 & 32,17 & 38,64 & 2 & 33,80 & 40,48 & 4 \\
\hline 30,60 & 36,86 & 8 & 32,23 & 38,71 & 0,9541 & 33,86 & 40,55 & 3 \\
\hline 30,66 & 36,93 & 7 & 32,29 & 38,78 & 0,9540 & 33,91 & 40,61 & 2 \\
\hline 30,72 & 37,00 & 6 & 32,35 & 38,85 & 0.9539 & 33,97 & 40,67 & 1 \\
\hline 30,79 & 37,08 & 5 & 32,40 & 38,90 & 8 & 34,00 & 40,71 & 0,95105 \\
\hline 30,85 & 37,15 & 4 & 32,46 & 38,97 & 7 & 34,03 & 40,74 & 0,9510 \\
\hline 30,91 & 37,22 & 3 & 32,52 & 39,04 & 6 & 34,08 & 40,80 & 0,9509 \\
\hline 30,97 & 37,28 & 2 & 32,58 & 39.11 & 5 & 34,14 & 40,86 & 8 \\
\hline 31,00 & 37,31 & 14 & 32,64 & 39,18 & 4 & 34,19 & 40,92 & 7 \\
\hline 31,03 & 37,35 & 1 & 22,70 & 39,24 & 3 & 34,25 & 40,99 & 6 \\
\hline 31,09 & 37,42 & 0,9560 & 32,75 & 39,30 & 2 & 34,30 & 41,05 & 5 \\
\hline 31,15 & 37,49 & 0.9559 & 32,81 & 39,37 & 1 & 34,36 & 41,11 & 4 \\
\hline 31,21 & 37,55 & 8 & 32,87 & 39,44 & 0,9530 & 34,41 & 41,17 & 3 \\
\hline 31,27 & 37,62 & 7 & 32,93 & 39,51 & 0,9529 & 34,47 & 41,23 & 22 \\
\hline 31,33 & 37,69 & 6 & 32.99 & 39,57 & 8 & 34.52 & 41,29 & 1 \\
\hline 31,39 & 37,76 & 5 & 33,00 & 39,59 & 79 & 34,58 & 41,35 & 0,9500 \\
\hline 31,45 & 37,83 & 4 & 33,05 & 39,64 & 7 & 34,64 & 41,42 & 0,9499 \\
\hline 31,51 & 37,90 & 3 & 33,11 & 39,71 & 6 & 34,69 & 41,48 & 8 \\
\hline 31,57 & 37,97 & 2 & 33,17 & 39,78 & 5 & 34,75 & 41,55 & 7 \\
\hline 31,63 & 38,03 & 1 & 33,23 & 39,84 & 8 & 34,80 & 41,60 & 6 \\
\hline 31.60 & 38,10 & 0,9550 & $\mathbf{3 3 , 2 8}$ & 39,90 & 3 & 34,86 & 41.67 & 5 \\
\hline
\end{tabular}


TABELA I (Continuagáo)

\begin{tabular}{|c|c|c|c|c|c|c|c|c|}
\hline $\begin{array}{l}\text { F de álcool } \\
\text { en pon }\end{array}$ & $\begin{array}{l}\text { \% de álcool } \\
\text { om volume }\end{array}$ & $\begin{array}{c}\text { Peso esped- } \\
\text { Iteo }: \\
15^{\circ} / 15^{\circ} \mathrm{C}\end{array}$ & $\left|\begin{array}{c}\% \text { de íleool } \\
\text { em póso }\end{array}\right|$ & $\begin{array}{l}\text { \% de álcool } \\
\text { em volume }\end{array}$ & 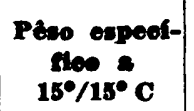 & \% de álecol & $\begin{array}{l}\text { \% de álcool } \\
\text { em volume }\end{array}$ & $\begin{array}{c}\text { P6oo espeof- } \\
\text { fleo }: \\
15^{\circ} / 15^{\circ} \mathrm{C}\end{array}$ \\
\hline 34,02 & 41,74 & 4 & $\overline{36,40}$ & 43,39 & 7 & 87,89 & 45,03 & 0,9439 \\
\hline 34,08 & 41,80 & 0,9493 & 36,46 & $43,4,5$ & 6 & 37,94 & 45,08 & 8 \\
\hline 35,00 & 41,83 & 24 & 36,51 & 43,50 & 5 & 37,99 & 45,13 & 7 \\
\hline 35,03 & 41,86 & 2 & 36,56 & 43,56 & 4 & 38,00 & 45,14 & 69 \\
\hline 35,09 & 41,93 & 1 & 36,62 & 43,63 & 3 & 38,05 & 45,20 & 6 \\
\hline 35,14 & 41,90 & 0,9490 & 36,67 & 43,68 & 2 & 38,10 & 45,26 & 5 \\
\hline 35,20 & 42,05 & 0,9489 & 36,72 & 43,74 & 1 & 38,15 & 45,31 & 4 \\
\hline 35,25 & 42,11 & 8 & 36,78 & 43,80 & 0,9460 & 38,20 & 45,36 & 3 \\
\hline 35,31 & 42,17 & 7 & 36,83 & 43,86 & 0,9459 & 38,25 & 45,42 & 2 \\
\hline 35,36 & 42,23 & 6 & 36,88 & 43,92 & 8 & $\mathbf{3 8 , 3 1}$ & 45,40 & 1 \\
\hline 35,42 & 42,30 & 5 & 36,94 & 43,98 & 7 & 38,36 & 45,54 & 0,9430 \\
\hline 35,47 & 42,35 & 4 & 36,80 & 44,03 & 6 & 38,41 & 45,59 & 0,9429 \\
\hline $\mathbf{3 5 , 5 3}$ & 42,42 & 3 & 37,00 & 44,05 & 59 & 38,46 & 45,65 & 8 \\
\hline 35,58 & 42,48 & 2 & 37,05 & 44,10 & 5 & 38,51 & 45,71 & 7 \\
\hline 35,64 & 42,54 & 1 & 37,10 & 44,16 & 4 & $\mathbf{3 8 , 5 7}$ & 45,77 & 6 \\
\hline 35,69 & 42,60 & 0,9480 & 37,15 & 44,21 & 3 & 38,62 & 45,83 & 5 \\
\hline 35,75 & 42,68 & 0,9479 & 37,20 & 44,27 & 2 & 38,67 & 45,88 & 4 \\
\hline 35,80 & 42,72 & 8 & 37,26 & 44,32 & 1 & 38,72 & 45,94 & 3 \\
\hline 35,86 & 42,78 & 7 & 37,30 & 44,38 & 0,9450 & 38,77 & 45,90 & 2 \\
\hline 35,91 & 42,84 & 6 & 37,35 & 44,43 & 0,9449 & 38,82 & 46,04 & 1 \\
\hline 35.97 & 42,90 & 5 & 37,40 & 44,49 & 8 & 38,88 & 46,11 & 0,9420 \\
\hline 36,00 & 42,94 & 45 & 37,46 & 44,55 & 7 & 38,93 & 46,16 & 0,0419 \\
\hline 36,03 & 42,88 & 4 & 37,51 & 44,60 & 0,9446 & 38,98 & 46,22 & 8 \\
\hline 36,08 & 43,03 & $\mathbf{3}$ & 37,56 & 44,66 & 5 & 39,00 & 46,24 & 76 \\
\hline 36,14 & 43,10 & 2 & 37,61 & 44,72 & 4 & 39,03 & 46,27 & 7 \\
\hline 36,10 & 43.15 & 1 & 37,67 & 44,78 & 3 & 39,09 & 46,34 & 6 \\
\hline 36,24 & 43,21 & 0,9470 & 37,73 & 44,85 & 2 & 39,14 & 46,39 & 5 \\
\hline 36,30 & 43,27 & 0,9469 & 37.78 & 44,90 & 1 & 39,10 & 46,44 & 4 \\
\hline 36.35 & 43,33 & 8 & 37.83 & 44,88 & 0,9440 & 39,24 & 46.50 & 3 \\
\hline
\end{tabular}


TABELA I (Continuação)

\begin{tabular}{|c|c|c|c|c|c|c|c|c|}
\hline $\begin{array}{l}\text { y de álcool } \\
\text { em pôso }\end{array}$ & $\begin{array}{l}\% \text { de alcool } \\
\text { em volume }\end{array}$ & $\begin{array}{c}\text { Peso especi- } \\
\text { fico } 2 \\
15^{\circ} / 15^{\circ} \mathrm{C}\end{array}$ & $\left|\begin{array}{c}\% \text { de plooel } \\
\text { em pêto }\end{array}\right|$ & $\begin{array}{l}\text { \% de áleool } \\
\text { em volume }\end{array}$ & $\begin{array}{c}\text { Pêso espeoi- } \\
\text { fico a } \\
15^{\circ} / 15^{\circ} \mathbf{C}\end{array}$ & $\begin{array}{c}\% \text { de áleool } \\
\text { em paes }\end{array}$ & $\begin{array}{l}\% \text { de alceel } \\
\text { em volume }\end{array}$ & $\begin{array}{c}\text { Pôso espect- } \\
\text { fles : } \\
15 \% / 15^{\circ} \mathrm{C}\end{array}$ \\
\hline 39,30 & 46,57 & 2 & 40,75 & 48,14 & 3 & $4 \overline{2}, 13$ & $49, \ddot{62}$ & 5 \\
\hline 39,35 & 46,62 & $i$ & 40,80 & 48,19 & 2 & 42,18 & 49,67 & 4 \\
\hline 39,40 & 46,68 & 0,9410 & 40.85 & 48,25 & 1 & 42,23 & 49,72 & 3 \\
\hline 39,45 & 46,73 & 0,9409 & 40,80 & 48,30 & 0,9380 & 42,28 & 49.78 & 2 \\
\hline 39,50 & 46,79 & $a$ & 40,95 & 48,35 & 0.9379 & 42,33 & 49.83 & 1 \\
\hline 39,55 & 46,84 & 7 & 41,00 & 48,40 & 8 & 42,37 & 48,87 & 0,9350 \\
\hline 39,60 & 46.89 & 6 & 41.05 & 48,46 & 7 & 42,42 & 49,93 & 0,9349 \\
\hline 39,65 & 46,95 & 5 & 41,10 & 48,51 & 6 & 42,47 & 49,98 & 8 \\
\hline 39,70 & 47,01 & 4 & 41,15 & 48,54 & 5 & 42,52 & 50,03 & 7 \\
\hline 39,75 & 47.06 & 3 & 41,20 & 48,62 & 4 & 42,57 & 50,09 & 6 \\
\hline 39,80 & 47,11 & 2 & 41,25 & 48,67 & 3 & 42,62 & 50,14 & 5 \\
\hline 39,85 & 47.17 & 1 & 41,30 & 48,72 & 2 & 42,66 & 50,19 & 4 \\
\hline 39,90 & 47,22 & 0.9400 & 41,35 & 48,78 & 1 & 42,71 & 50,24 & 3 \\
\hline 39,95 & 47,27 & 0,9399 & 41.40 & 48,83 & 0.9370 & 42,76 & 50,29 & 2 \\
\hline 40,00 & 47,33 & 0.9398 & 41.45 & 48,89 & 9 & 42,81 & 50,34 & 1 \\
\hline 40,05 & 47,38 & 7 & 41,50 & 48,94 & 8 & 42,86 & 50,40 & 0,9340 \\
\hline 40,10 & 47,44 & 6 & 41.54 & 48,99 & 7 & 42,91 & 50,45 & 0,9339 \\
\hline 40,15 & 47,49 & 5 & 41,59 & 49,03 & 6 & 42,96 & 50,50 & 8 \\
\hline 40,20 & 47,54 & 4 & 41,64 & 49,09 & 5 & 43,00 & 50,54 & 72 \\
\hline 40,25 & 47,60 & 3 & 41,69 & 49,15 & 4 & 43,01 & 50,56 & 7 \\
\hline 40,30 & 47,66 & 2 & 41,74 & 49,20 & 3 & 43,06 & 50,61 & 6 \\
\hline 40,35 & 47,71 & 1 & 41,79 & 49,25 & 2 & 43,11 & 50,67 & 5 \\
\hline 40,40 & 47,76 & 0,9390 & 41,84 & 49,31 & 1 & 43,16 & 50,72 & 4 \\
\hline 40,45 & 47,82 & 0,9389 & 41,89 & 49,36 & 0,9360 & 43,21 & 50,77 & 3 \\
\hline 40,50 & 47,87 & 8 & 41,94 & 49,41 & 0,8359 & 43,25 & 50,81 & 2 \\
\hline 40,55 & 47,92 & 7 & 41,99 & 49,47 & 8 & 43,30 & 50,86 & 1 \\
\hline 40,60 & 47,98 & 6 & 42,00 & 49,48 & 78 & 43,35 & 50,91 & 0.9330 \\
\hline $40 ; 65$ & 48,03 & 5 & 42,03 & 49,51 & 7 & 43,40 & 50,07 & 0,9329 \\
\hline 40,70 & 48,08 & 4 & 42,08 & 49.56 & 6 & 43,45 & 51,02 & 8 \\
\hline
\end{tabular}


TABELA I (Continuaça)

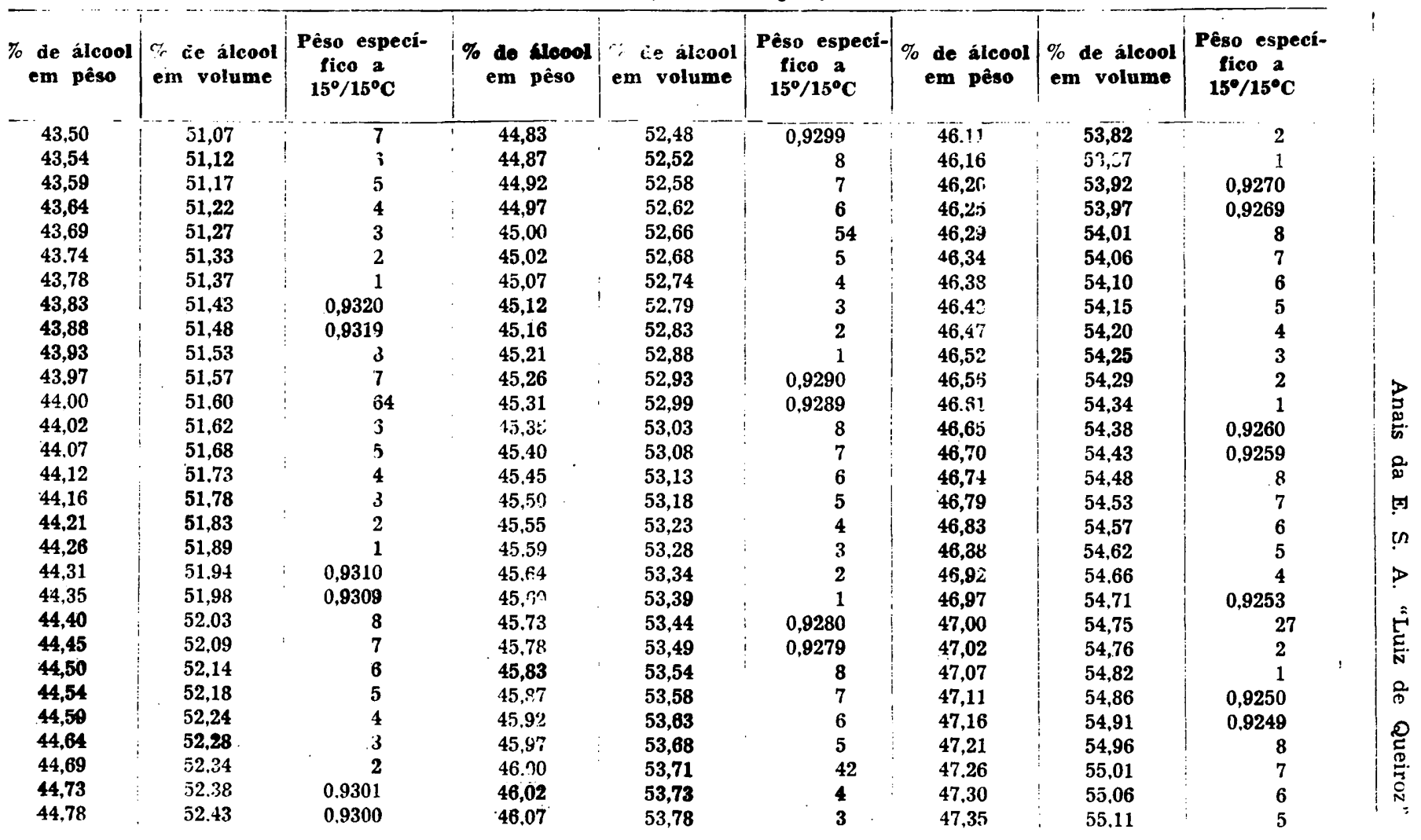


TABELA I (Conclusão)

\begin{tabular}{|c|c|c|c|c|c|c|c|c|}
\hline $\begin{array}{c}\text { \% de álcool } \\
\text { em pêso }\end{array}$ & $\begin{array}{l}c \% \text { de alcool } \\
\text { em volume }\end{array}$ & $\begin{array}{l}\text { Pese esped- } \\
\text { fiee a } \\
15^{\circ} / 15^{\circ} \mathrm{C}\end{array}$ & $\begin{array}{c}\% \text { de álcool } \\
\text { em pêso }\end{array}$ & $\begin{array}{l}\% \text { de álcool } \\
\text { em volume }\end{array}$ & $\begin{array}{l}\text { Pêso especí- } \\
\text { fico a } \\
15^{\circ} / 15^{\circ} \mathrm{C}\end{array}$ & $\begin{array}{c}\% \text { de alcool } \\
\text { em pêso }\end{array}$ & $\begin{array}{l}\% \text { de álcool } \\
\text { em volume }\end{array}$ & $\begin{array}{c}\text { Pêso especi- } \\
\text { fico } 2 \\
15^{\circ} / 15^{\circ} \mathrm{G}\end{array}$ \\
\hline 47,40 & 55,16 & 4 & 48,74 & 56,54 & 5 & 50,01 & 57,84 & 7 \\
\hline 47,45 & 55,21 & $\mathbf{3}$ & 48,79 & 56.59 & 4 & 50,05 & 57,88 & 6 \\
\hline 47,49 & 55,25 & 2 & 48,84 & 56,64 & 3 & 50,10 & 57,93 & 5 \\
\hline 47,54 & 55,31 & 1 & 48,88 & 56,69 & 2 & 50,14 & 57,97 & 4 \\
\hline 47,59 & 55,36 & 0,8240 & 48,03 & 56,74 & 1 & 50,19 & 58,02 & 3 \\
\hline 47,64 & 55,41 & 0,9239 & 48,97 & 56,78 & 0,9210 & 50,23 & 58,07 & 2 \\
\hline 47,68 & 55,45 & 8 & 49,00 & 56.81 & 0.9209 & 50,28 & 58.12 & 1 \\
\hline 47,73 & 55,50 & 7 & 49,01 & 56,82 & 92 & 50,32 & 58.16 & 0,9180 \\
\hline 47,78 & $\mathbf{5 5 , 5 5}$ & 6 & 49,05 & 56,86 & 8 & 50,37 & 58,21 & 0,9179 \\
\hline 47,82 & 55,59 & 5 & 49,10 & 56,91 & 7 & 50.41 & 58,25 & 8 \\
\hline 47,86 & 55,64 & 4 & 49.14 & 56,95 & 0,9206 & 50,46 & 58,30 & 7 \\
\hline 47,91 & 55,69 & 3 & 49,19 & 57,02 & 5 & 50.51 & 58,35 & 6 \\
\hline $47, \otimes 8$ & 55,74 & 2 & 49,29 & 57,05 & 4 & 50,56 & 58,40 & 5 \\
\hline 48,00 & 55,78 & 11 & 49,28 & 57,09 & 3 & 50,60 & 58,44 & 4 \\
\hline 48,01 & 55,79 & 1 & 49,33 & 57.14 & 2 & 50,65 & 58,49 & 3 \\
\hline 48,05 & 55,83 & 0,9230 & 49,37 & 57,19 & 1 & 50,69 & 58,53 & 2 \\
\hline 48,10 & 55,89 & 0,9229 & 49,42 & 57,24 & 0.9200 & 50,74 & 58,58 & 1 \\
\hline 48,15 & 55,94 & 8 & 49,47 & 57,29 & 0.9199 & 50.78 & 58,62 & 0,9170 \\
\hline 48,10 & 55,98 & 7 & 49,51 & 57,33 & 8 & 50,83 & 58,67 & 0,8169 \\
\hline 48,24 & 56,03 & 6 & 49,56 & 57,38 & 7 & 50,87 & 58,71 & 8 \\
\hline 48,28 & 56,07 & 5 & 49.60 & 57,42 & 6 & 50,92 & 58,76 & 7 \\
\hline 48,33 & 56,12 & 4 & 49,65 & 57,47 & 5 & 50,96 & 58,80 & 6 \\
\hline 48,38 & 56,17 & 3 & 49.70 & 57,52 & 4 & 51,00 & 58.84 & 51 \\
\hline 48,42 & 56,21 & 2 & 49,74 & 57.56 & 3 & 51,01 & 58,86 & 5 \\
\hline 48,47 & 56,26 & 1 & 49,79 & 57,61 & 2 & 51,05 & 58,90 & 4 \\
\hline 48,51 & 56,31 & 0,9220 & 49,83 & 57.66 & 1 & 51,10 & 58,95 & 3 \\
\hline 48,56 & 56,36 & 0,0219 & 49,88 & 57,71 & 0,9190 & 51.14 & 58,99 & 2 \\
\hline 48,61 & 56.41 & 8 & 49,93 & 57,76 & 0.9189 & 51,19 & 59.04 & 1 \\
\hline 48,65 & 56,45 & 7 & 49,97 & 57.80 & 8 & 51,23 & 59,03 & 0,9160 \\
\hline 48.70 & 56,50 & 6 & 50,00 & 57,83 & 73 & 51,28 & 59,13 & 0.9159 \\
\hline
\end{tabular}


Os resultados obtidos pelos autores vãc expressos no quadro abıixo.

QUADRO V - Alteração do grau alcoólico das aguarukintes

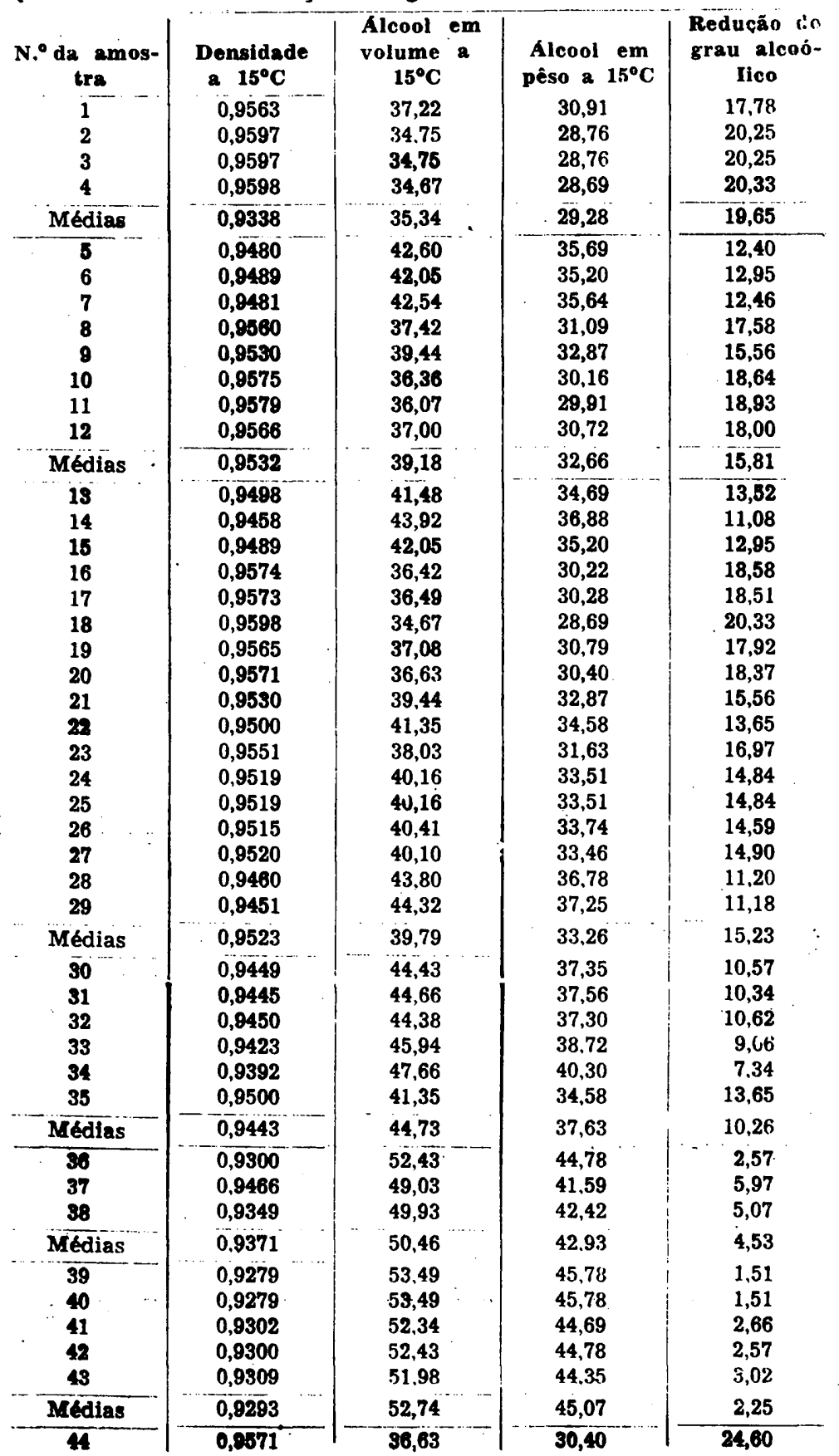




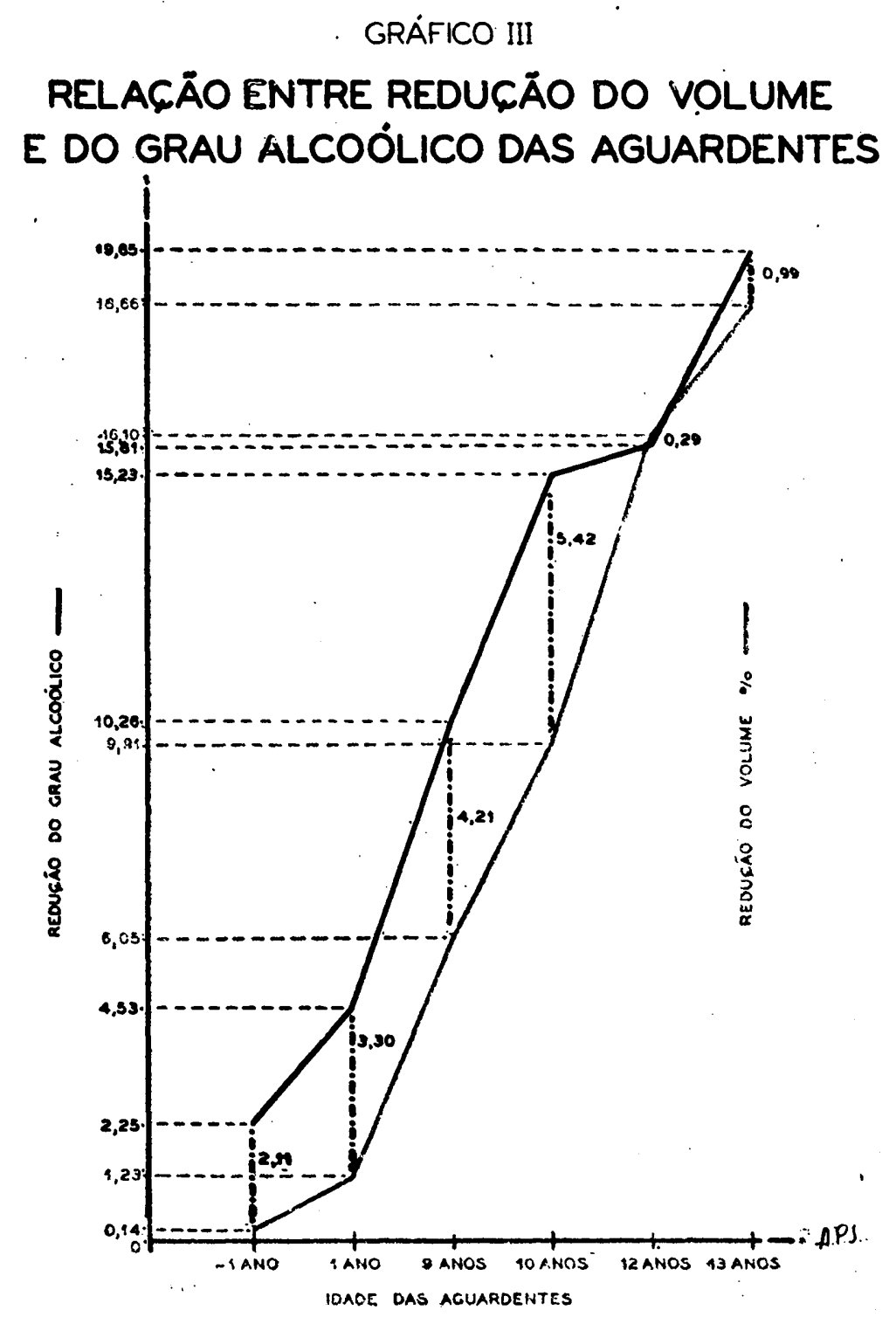


Fxaininando-se primeiramente as médias especificadas no quadro antericr e conparando tais resultados com as médias relativas à diminuiça o do volume, constantes no quadro $\mathrm{V}$, nota-se que no crmeço do envelhecimento a diferença entre a diminuiçáo to vclume e da graduaçáo alcoólica, é relativamente peque:la; acentua-se ciepois, para, ao cabo de cerrca de 10 anos desapartcer praticamente. O gráfico III mostra isso com bastante clareza.

Admitem a!guns autores que numa pipa (500 litros) de madetra, a diminuiçáo da graduaçáo alcoólica seja de 6 a $8 \%$ no $1 .{ }^{\circ}$ ano de conservaçá; de 4 a $6 \%$ no $2 .^{\circ}$ ano; de 3 a $4 \%$ no $3 .^{\circ}$ ano; de 2 a $3 \%$ no $4 . .^{\circ}$ ano e de 1 a $2 \%$ nos anos seguintes. Assim sendo, a intensidade da perda da graduação diminui regularmente com o nvelhecimento.

Ista diminuiçáo do grau alcólico, diretamente relacionada coin a temperatura e estado higrométrico do ambiente, natureza e timensరes do vasilhame, náo se verificou assim de maneir: regular, embora sempre houvesse reduçăo de volume a.o lađo de reduçáo da graduaçáo alcoólica.

o exame individual das amostras mostra que năo há proporciona!:dade entre queda de volume e de graduação. Assim a amostra 4, apesar de ter sido a que maior diminuiçăo de volume acusıu $(58 \%)$; sofreu uma queda na sua graduação alcoblica $(20,33 \%)$ tgual à amostra 18 , que apenas revelou uma diminulção de volume de $32 \%$.

As amostras 10,11,12,16, 17 e 20 apresentaram. em números inteiros, a mesma queda de graduaçăo (18\%), năo obstante terem sofrido diminuição de volume muito diferente, correspouidente à $29,30,15,11,12$ e $13 \%$, respectivamente.

Esta diversidade de resultados vem mais uma vez confirmar que a jueda do volume e da graduaçáo alcoblica de uma aguardente em envelhecimento, depende năo só da natureza do prodisto em conservaçáo, bem como do tipo de vasilhame usado e cas condiçóes de ambiencia a que está sujeito, năo se poderido, por isso, fixar númeras rijidos para especificar a intensidade da evaporação do álcool e da água ou de ambos.

\section{4 - PESO ESPECTFICO}

O peso especifico informa acêrca da proporção de resíduos ou suk stáncias solúveis contidas numa determinada aguardente.

Jia sabemos que, pela açáo combinada do álcool e da água, diversas matérias corantes e odorantes da madeira vão sendo dissolvidas, aos poucos, dando à aguardente cor e gosto caracte- 
rístic $\cdot s$. No casr do carvalho é a quercitina a principal matéria corante :esponsável pela cor de ouro velho da aguardente envelhtcida, enquanto que a quercina se incumbe de comunicarthe o aroma particular que faz o produto mais apreciado depois de algum tempo de conservaçăo.

Sáo justamente estas matérias dissolvidas que văo formar o extrato e as cinzas das aguardentes e, consequentemente, aumentar o seu peso especifico. Assim sendo, quanto malor o péso especifico dn aguardente, maior o extrato e menor a sua graduaçẽo alcoólica.

Sendo então o péso especifico funçáo da riqueza alcoólica da aguardente, é claro que quanto maior for a queda do grau alcodilico ta aguardente em enyelhecimento maior será a elevaçáo do pêso especifico. Em outras palavras, à medida que a aguaruente envelhece o peso especifico aumenta, porque pela evaporaçáo do álcool ela val cada vez se enriquecendo de água e de extrato.

As determinaçoes do peso especifico foram feitas com a balança de Westphal, com as amostras resfriadas exatamente a $15^{\circ} \mathrm{C}$. obtendo-se os resultados constantes do quadro adeante.

\section{QUADRO VI}

Péso especifico das aguardentes

\begin{tabular}{|c|c|c|c|c|c|}
\hline $\begin{array}{c}\text { N.o da amow- } \\
\text { tra }\end{array}$ & $\begin{array}{r}\text { Pêso especi- } \\
\text { floo a } 15^{\circ} \mathrm{C}\end{array}$ & $\begin{array}{l}\text { N.o da } \\
\text { amos!ra }\end{array}$ & $\begin{array}{l}\text { Pèso especi- } \\
\text { fico a } 15^{\circ} \mathrm{C}\end{array}$ & $\mid \begin{array}{c}\text { N.o da amos- } \\
\text { tra }\end{array}$ & $\begin{array}{l}\text { Péso especi- } \\
\text { flco a } 15^{\circ} \mathrm{C}\end{array}$ \\
\hline 1 & 0.9580 & 13 & 0,9530 & 30 & 0,9450 \\
\hline 2 & 0.9609 & 14 & 0,9539 & 31 & 0,8482 \\
\hline 3 & 0.9610 & 15 & 0,9579 & 32 & 0,9500 \\
\hline 4 & 0.9835 & 16 & 0.9735 & 33 & 0,9451 \\
\hline & & 17 & 0.9530 & 34 & 0,9456 \\
\hline Média & 0.9658 & 18 & 0.9602 & 35 & 0,9519 \\
\hline 5 & 0.9572 & 19 & $\begin{array}{l}0.9651 \\
0.9588\end{array}$ & Média & 0,9478 \\
\hline 6 & 0.9571 & $\begin{array}{l}20 \\
21\end{array}$ & $\begin{array}{l}0,9580 \\
0,9563\end{array}$ & 36 & 0.9879 \\
\hline 7 & 0.9570 & $\begin{array}{l}21 \\
22\end{array}$ & 0.9525 & 37 & 0,9512 \\
\hline $\begin{array}{l}8 \\
9\end{array}$ & $\begin{array}{l}0,9579 \\
0.9536\end{array}$ & 23 & 0.9674 & $\begin{array}{c}38 \\
\text { Média }\end{array}$ & $\begin{array}{l}0.9506 \\
0.9632\end{array}$ \\
\hline 10 & 0.9579 & 24 & 0,9622 & & \\
\hline 11 & 0.9574 & 25 & 0.9618 & 39 & 0,9340 \\
\hline 12 & 0,9574 & 26 & 0.9615 & 40 & 0,9345 \\
\hline & & 27 & 0.9642 & 41 & 0,8352 \\
\hline Média & 0,9571 & 28 & 0,9540 & 42 & 0,9372 \\
\hline & & 29 & 0.9476 & $\begin{array}{c}43 \\
\text { Média }\end{array}$ & $\begin{array}{l}0,8350 \\
0.935\end{array}$ \\
\hline & & Média & 0.9413 & & 51 \\
\hline & 1 & i & $i$ & 44 & 0,9696 \\
\hline
\end{tabular}


Observa-se que as amastras 3,4 e 44 que sto aguardentes forternente coloridas, deram por isso, alto peso especiftco e baixa graduaçęn alcoolica. A amostra 36, apresenta-se também multo colorida, com alto peso especifico, porém tambem com alta gradiaças alcoblica porque e aguardente colorida artificialmente ccm extrato de carvalho.

Constata-s: pelo exame das médias que, confirmando o que haviamos dito antes, de um modo geral, a medida que a aguartente envelhece o seu peso especifico se eleva :

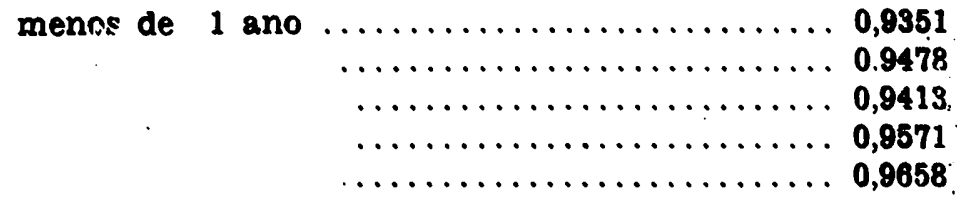

Daixgmos de considerar aqui as aguardentes de 36 a 38 porque san aguardentes artificialmente tratadas para envelhecimento:

Para tornat mals clara a relaça entre cor, graduaçáo alcoolic:a - peso especifico, construimos o graftco IV, de cujo exame se poderá constatar fácllmente e com precisáo que:

a - a cir aumenta $\mathrm{com}$ a idade de conservaçăo enquanto a grartuaçăo alcoblica diminui;

b - a uma cor mais intensa corresponde mais alto peso especifico;

c - a un mais alto peso especifico corresponde menor riqueza alcoblica.

\section{5 - EXTRATO}

P:10 aquecimento as aguardentes perdem os produtos voláteis como os alcoobis, os ácidos, os ésteres, etc., ficando as matérias fixns como residuo que se designa com o nome de extrato.

Vina iguardente recentemente distilada acusa, por. evaporaçáo uma quantidade minima de residuo ou de extrato. A medida que envelhece em condiçбes normais, o teor em extrato vai aumentando. Nestas cordiçoes, a maior ou menor riqueza de extrato esta, naturalmente, em relaçăo direta, embora năo proporcinnal, crm a intensidade da cor da aguardente. Assim sendri, as fatores que fazem variar a cor da aguardente szo c: mesmos que intluem sobre o seu teor em extrato.

I: fato. as aguardentes envelhecidas em recipientes de madeira, principalmente quando esta e rica em materias extrativas, săo sempre mais coloridas e dzo mais extrato, que $s^{2}$ fosser: conservadas em vasilhame impermeabilizado interna mente ou te vidro com rolha esmerilhada. 
Igualmente as aguardentes tratadas antes do envelhecimento com açucar, extrato de carvalho, glicerina, etc., acusam sempre una riqueza em extrato mais elevada que se nao fossem assim tratadas.

- Acreditamor que se pode considerar ótima, uma aguardente de cana normalmente envelhecida que acusar cerca de 4 grs. por Jitro, de exirato, quando conservada em recipiente de madeira.

Nia determinação do extrato seguimos a seguinte técnica analftica : mediante uma pipeta de 2 traços medem-se 25 cc. da aguarilente. os quals săo vertidos para uma pequena cápsula dc porcelana, de fundo chato. de 6 a $7 \mathrm{cms}$. de diametro, rigorosumente tarada. Evapora-se em banho-Maria ate secar. Nas inostras ricas de extrato, a evaporaçáo é felta até consistencia xaroposa. Em ambos os casos a evaporaça se completa $\mathrm{cm}$ nstufa a $100-105^{\circ} \mathrm{C}$ durante 2 a 3 horas.

Rosfria-se em dessecador com ácido sulfúrico e pesa-se a seguir, rápidamente. $O$ aumento de péso da capsula multiplicado por 40 dá o extrato, em grs. por litro de aguardente.

Cis resultados obtidos văo consignados no quadro abaixo:

QUADRO VII

Teor em extrato das aguardentes

\begin{tabular}{|c|c|c|c|c|c|}
\hline $\begin{array}{r}\text { N.o da } \\
\text { amos.tra } \\
\end{array}$ & $\begin{array}{c}\text { Extrato em } \\
\text { grs. por litro }\end{array}$ & $\begin{array}{c}\text { N.o da amos- } \\
\text { tra }\end{array}$ & $\begin{array}{l}\text { Extrato em } \\
\text { grs. por litro }\end{array}$ & $\begin{array}{c}\text { N.o da amos- } \\
\text { tra }\end{array}$ & $\begin{array}{l}\text { Extrato em } \\
\text { grs. por litro }\end{array}$ \\
\hline $\begin{array}{c}1 \\
2 \\
3 \\
4 \\
\text { Média } \\
5 \\
6 \\
7 \\
8 \\
9 \\
10 \\
11 \\
12 \\
\text { Média } \\
\ldots \quad \\
. \\
\ldots\end{array}$ & $\begin{array}{l}1,4120 \\
1,4200 \\
1,7380 \\
3.9480 \\
1,5233 \\
1,2440 \\
1,2120 \\
1,6660 \\
1,5760 \\
0,9600 \\
1,1200 \\
1,6580 \\
1,1490 \\
1,3231\end{array}$ & \begin{tabular}{c}
13 \\
14 \\
14 \\
15 \\
16 \\
17 \\
18 \\
19 \\
20 \\
21 \\
21 \\
22 \\
23 \\
.24 \\
25 \\
26 \\
.27 \\
28 \\
29 \\
2 \\
\multicolumn{2}{|c}{ Média } \\
2.
\end{tabular} & $\begin{array}{l}0,7400 \\
0,5100 \\
0,6520 \\
0,9300 \\
0,8580 \\
0,8400 \\
0,9340 \\
0.9900 \\
0.7820 \\
0,7580 \\
0,8100 \\
0,8080 \\
0,8560 \\
0,8280 \\
0,8120 \\
0,8200 \\
0,6980 \\
0,8015\end{array}$ & $\begin{array}{c}30 \\
31 \\
32 \\
33 \\
34 \\
35 \\
\text { Média } \\
36 \\
36 \\
37 \\
38 \\
\text { Média } \\
39 \\
39 \\
40 \\
41 \\
42 \\
43 \\
\text { Média } \\
44\end{array}$ & $\begin{array}{l}0,6860 \\
0,5840 \\
0,6860 \\
0,7200 \\
0,7920 \\
0,9120 \\
0,7300 \\
4,2020 \\
1,6240 \\
1,2220 \\
1,4230 \\
0,2220 \\
0,1900 \\
0,3300 \\
0,6860 \\
0,2700 \\
0,3396 \\
3,5520\end{array}$ \\
\hline
\end{tabular}


O exfme destes dados nos revela que, por via de regra, as aguarientes pelo envelhecimento enriquecem-se de extrato:

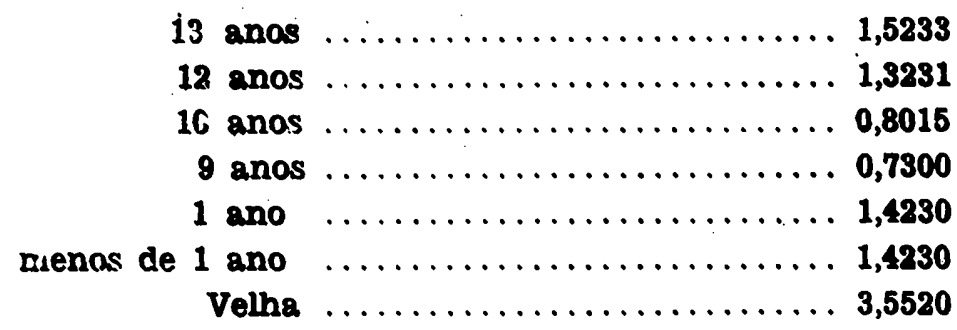

As divergeticias reveladas no grupo das aguardentes de 1 ano, se explicam, pois referem-se a produtos tratados artiflcialmente.

A cor das aguardentes seguiu muito aproximadamente esta mesm: ordfim, conforme se ve no grafico seguinte. As pequenas divergencias havidas sto consequencia exclusivamente das rôlhas, umas mais porasas que outras ou mals ricas de substancias extrativas.

A aguardente envelhecida em reciplente de madeira, como a n. 4. possui elevado extrato ao lado de uma cor intensa, caracteristicos esses, menos pronunclados que na amostra 96 que fol tritacia com extrato de carvalho.

1 proporçáo de extrato constitul um fator importante para distinguir os alcobis industriais das aguardentes envelhecidas, assim como serve, em certos casas, para indicar a adiçăo de matérís extranhas, fixas, solúveis, com o fim de simular um envelhecimento natural.

Comprando-se, por exemplo, os.resultados anteriores, com os obtido: de alcobis preparados pelos autores nos laboratorios de Tecnnlogia da Luiz de Queiroz e outros adquiridos no comerc!o, varifica.se. de fato, que o extrato nos alcobls é considerdvelmente muito menor que nas aguardentes. 
GÜUARRO VIII

romposiça de alcobis industrials

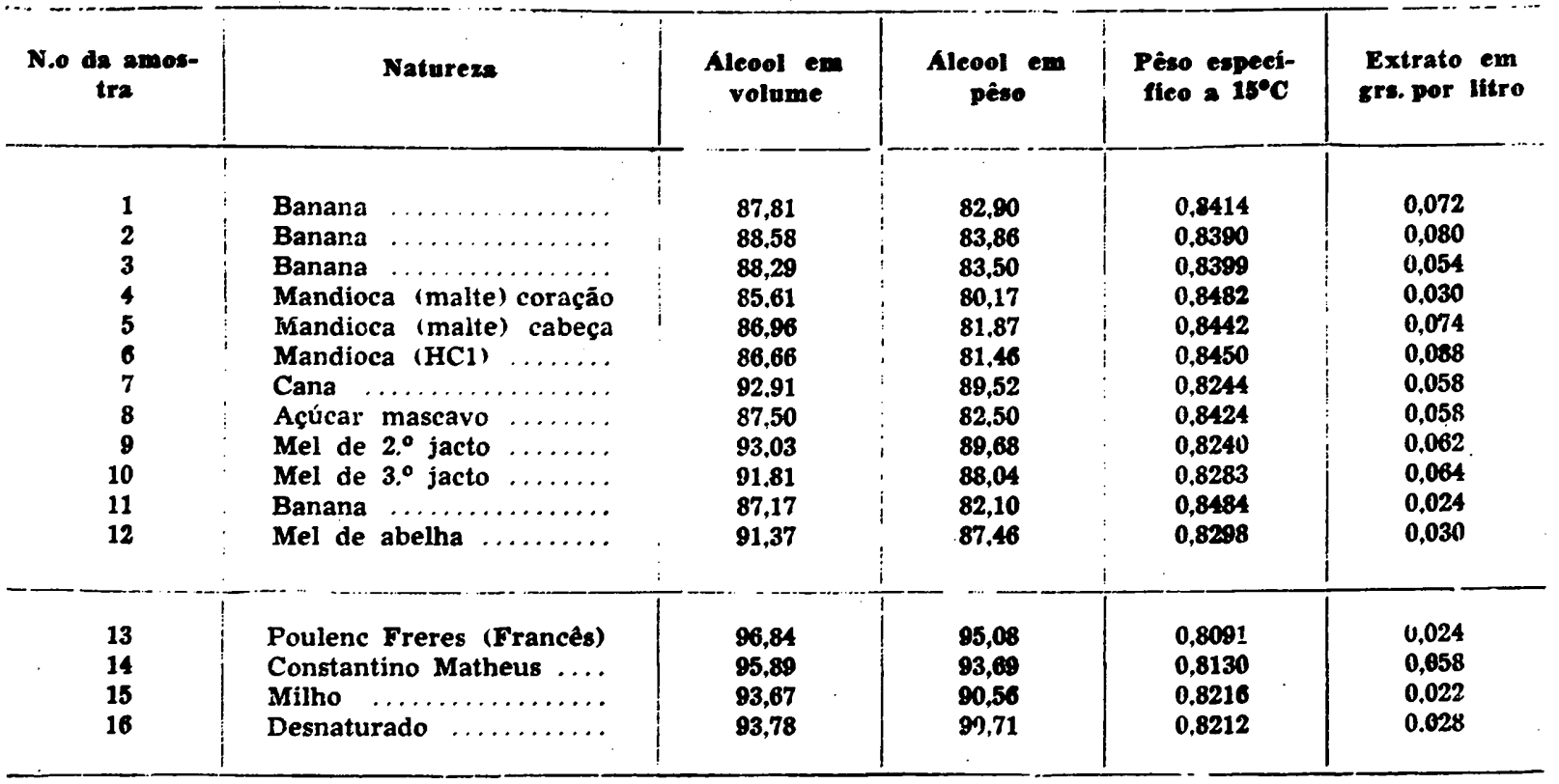




$$
\text { RELACAOO ENTRE PESO ESPECIFICO, }
$$
RIQUEZA ALCOÓLICA E CO̊R

DAS AGUARDENTES
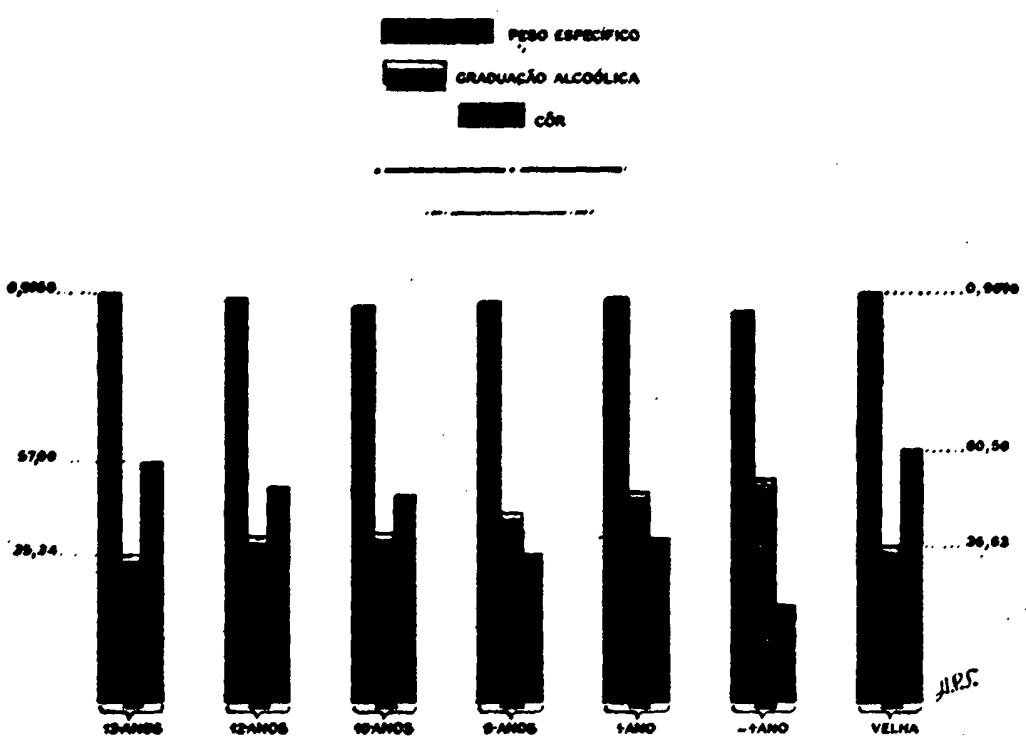


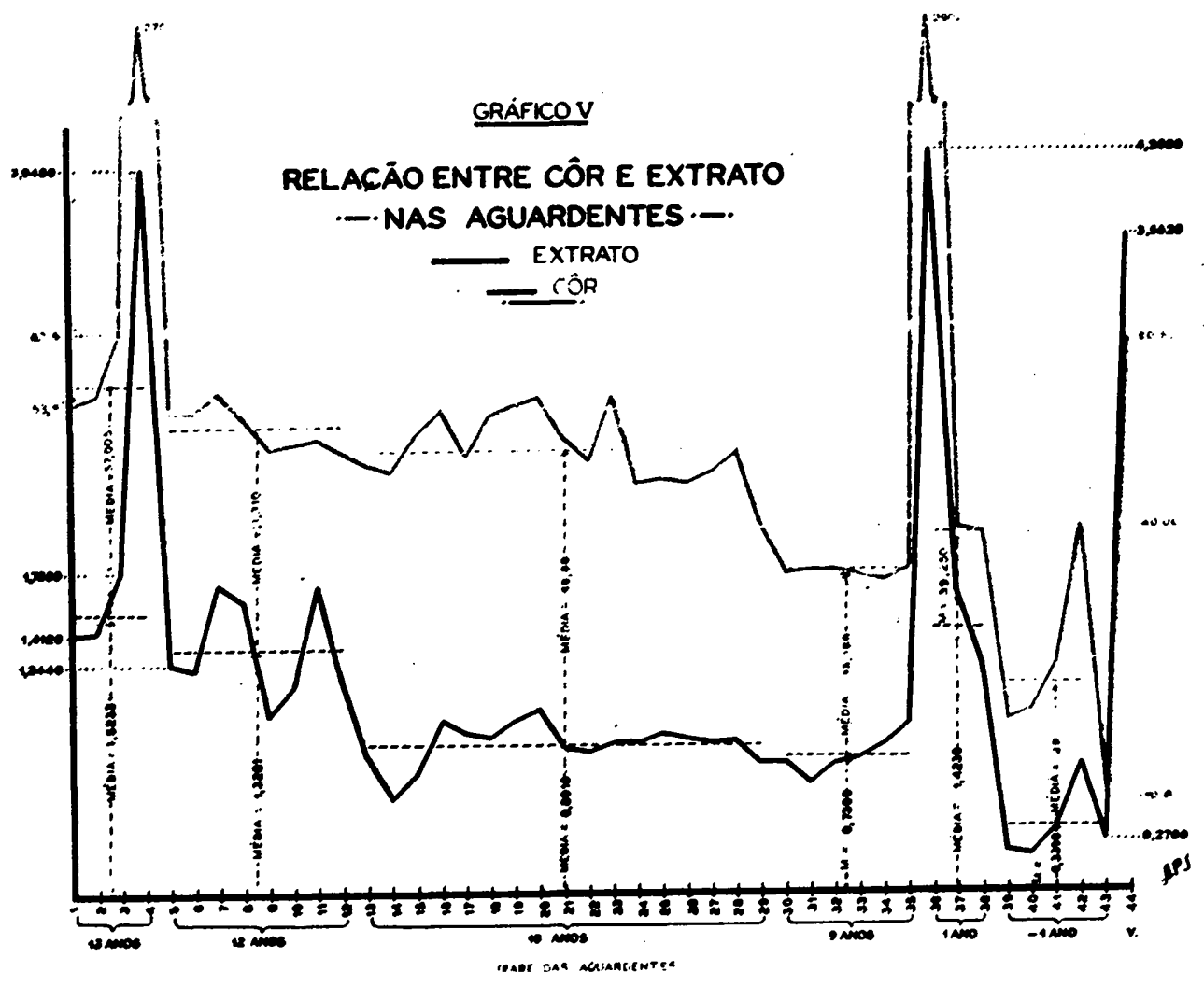


O gráfico V mostra a relaçáo entre extrato e cor das aguardentes examinadas Observe-se neste gráfico, principalmente a regularidride desta relaçăo. Naturalmente aparecem amostras individua:s qur: fogem desta regularidade, mas nem por isso ela deixe de existir de modo evidente, como testemunham as valores médios

\section{6 - ACIDBS}

0 conhecinento exato do teor de acides de uma aguardente é de suma importancia, constituindo mesmo um fator de quali lade: se recordarmos que, pelo envelhecimento, os acidos reagindo com os alcoois vâo dar formaçáo aos esteres que ortginam os aromas.

Pelo envelhecimerito natural, as aguardentes ficam com sua acides elevada, desde que a sua conservaça tenha sido feita em vasilhame de madeira ou tamponado com rolha porosa, rics de materias extrativas.

Duas são as principais causas determinantes do aumento da acides das pingas velhas:

1 - z primeira é consequência da maior ou menor dissoluçăo do ácido tánico e matérias tanóides solúveis da madeira ou da rôlha de cortiça;

2 - a segunda, talvez mais importante que a primeira, é consequência da oxidação lenta do álcool pela açáo do oxigento do ar, donde a necessidade da porosidade do recivierte, pois sem esta aquela năo se produz.

Wssa jxidaråo, embora lenta, encontra apolo nas seguintes equaçס̃es químicas :

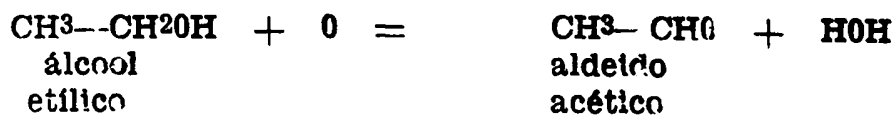

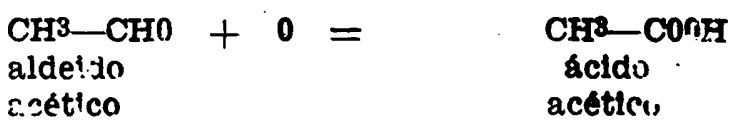

A. formaçăo do ácido acético neste caso é fruto de uma açăo pura'iente química, năo tendo interferencia nenhum micronrganismo capaz de produzir. igual fenomeno. 
Costuma-se exprimir a acides das aguardentes de 3 modos diferentes :

a) - comu acides total;

b! -- como acides fixa;

c) - como acides volátil,

sendo elas calculadas indiferentemente, em miligramos de ácido acetico por litro ou por 100 cc. Para o cómputo do coeficiente de impurezas. a acidês acética é sempre referida em miligramos de ácido acético por $100 \mathrm{cc}$. de álcool anidro ou seja a $100^{\circ}$ G.L

Us niétodos analíticos seguidos pelos autores nestes diferentes casos foram os seguintes:

\section{a) Determinação da acidês total}

Em n'm Erlenmever, tomam-se 50 cc. da aguardente e aquese-se em banho-Maria até ebuliçăo, para a eliminaçăo do anidrido carbónico.

Déixa-se esfriar, juntam-se 2 a 3 gotas de uma soluçăo alcobitca le fenolftaleina a $1 \%$ e titula-se com KOH o NaOH $n / 1$ até côoraçán rósea persistente.

O número de rc. lido na bureta, multiplicado por 12 , dá a acidês toţıl em miligramos de ácido acético por $100 \mathrm{cc}$.

Fara se calcular a acides relativa ao álcool considerado anidro $\therefore$ ultiplica-se o resultado anterior por 100 e divide-se pela grạduncáo alcoúlica da aguardente examinada.

\section{b) Determinação da acidês tixa}

F.vapora-se a sèco. em banho-Maria, 50 cc. da aguardente eir ur.ą cánsula de porcelana.

Dissolve-se o precipitado com água distilada e procede-se á determinaçán da acides fixa como se procedeu para a determinaçáo da acidês total, sendo preferível neste caso, fazer a titulação cim $\mathrm{KOH}$ ou $\mathrm{NaOH}$ n/100.

\section{c) Determinação da acidês volátil}

C-lcula-se por diferença entre a acidês total e a acidés fixa.

Oa resultados obtidos váo consignados no quadro abaixo. onde se vâm os valores calculados tanto em miligramos de ácido asetico por $100 \mathrm{cc}$ de aguardente, como para $100 \mathrm{cc}$. de álcool crnsiderado anidro. 
QUADRO IX

Acidés acética das aguardente:

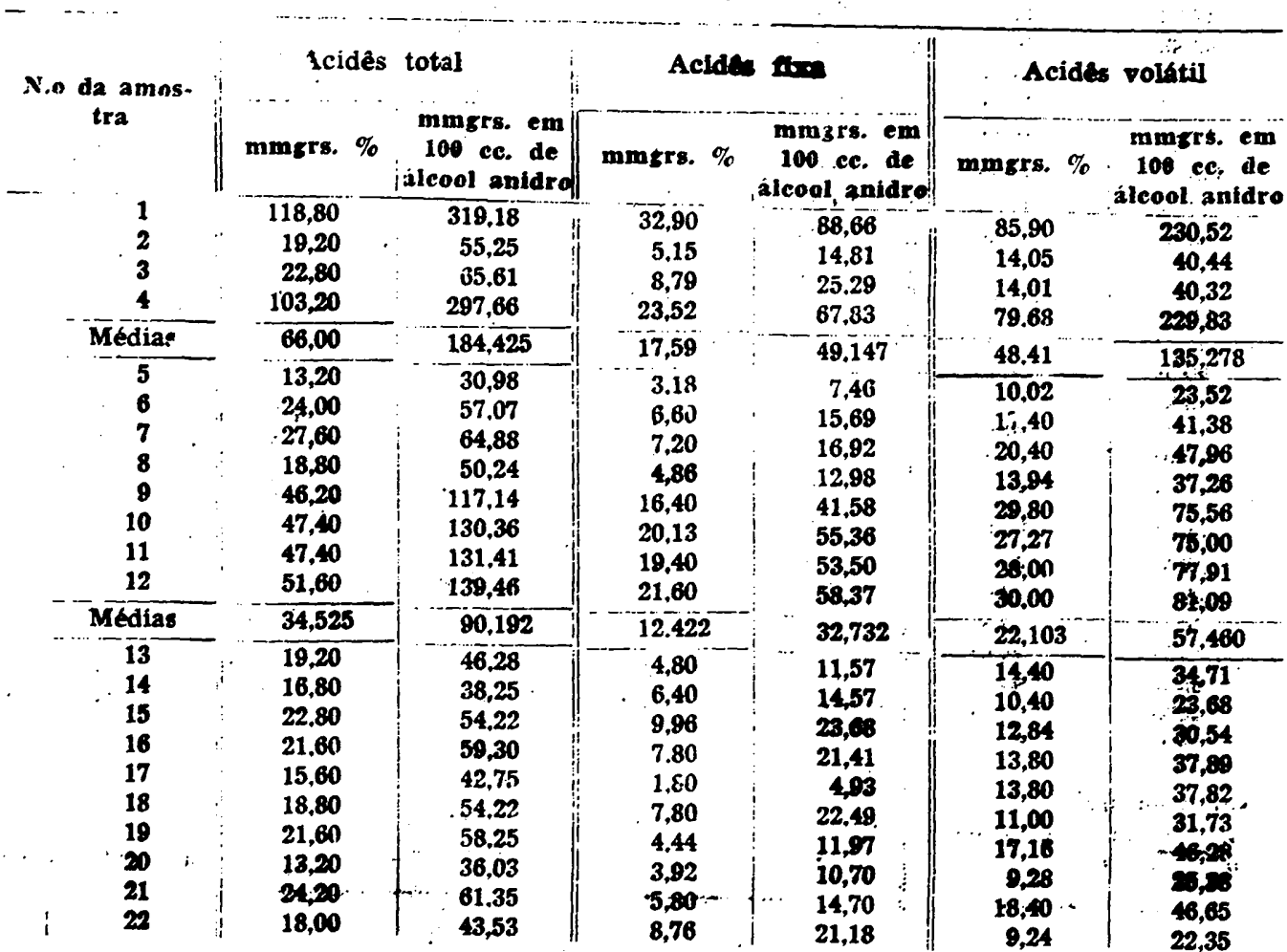


QU KDRO IX - Conclusăo

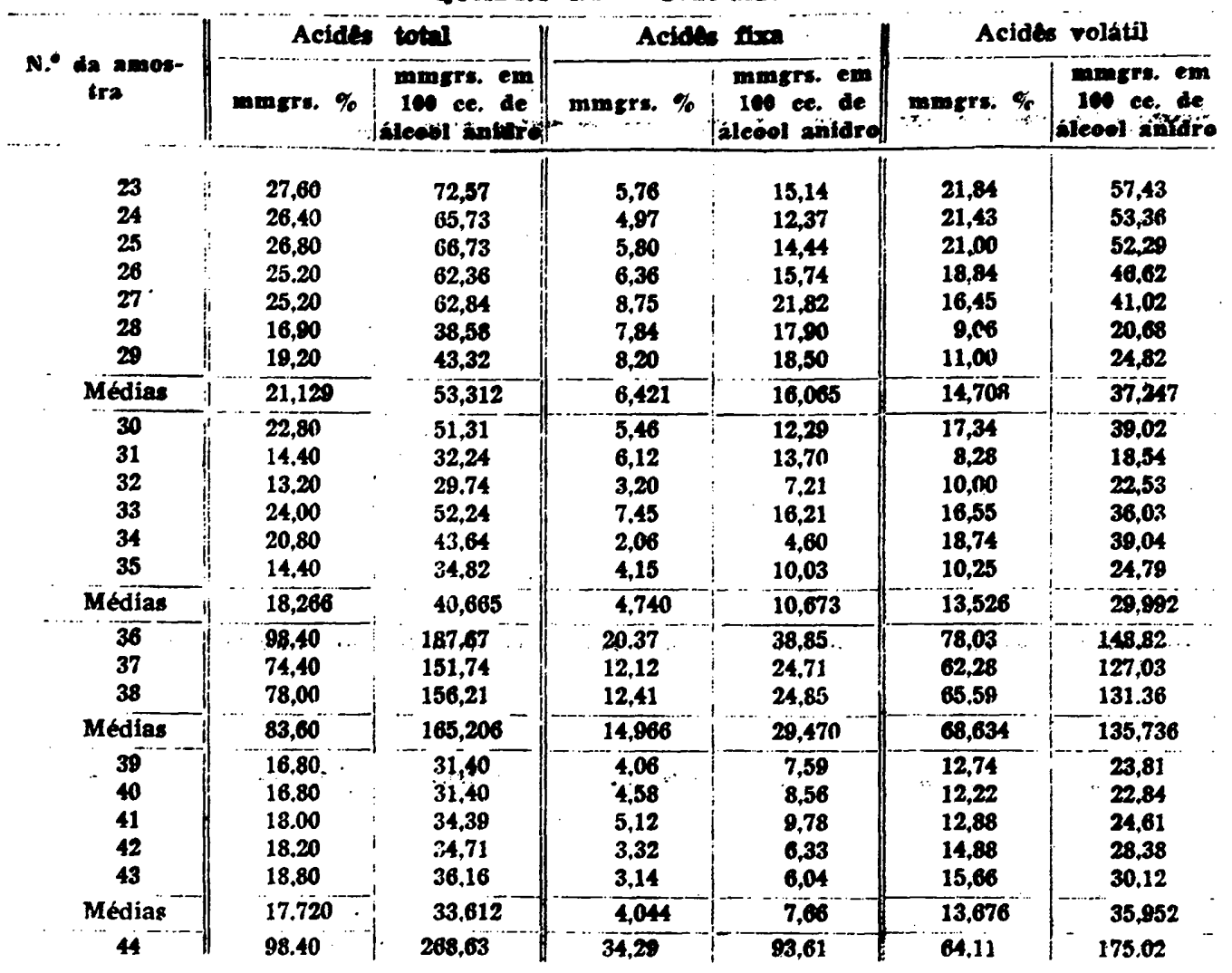


- GRÁFICO VI -.

\section{ACIDÊS TOTAL, FIXA E VOLATIL \\ DAS AGUARDENTES}

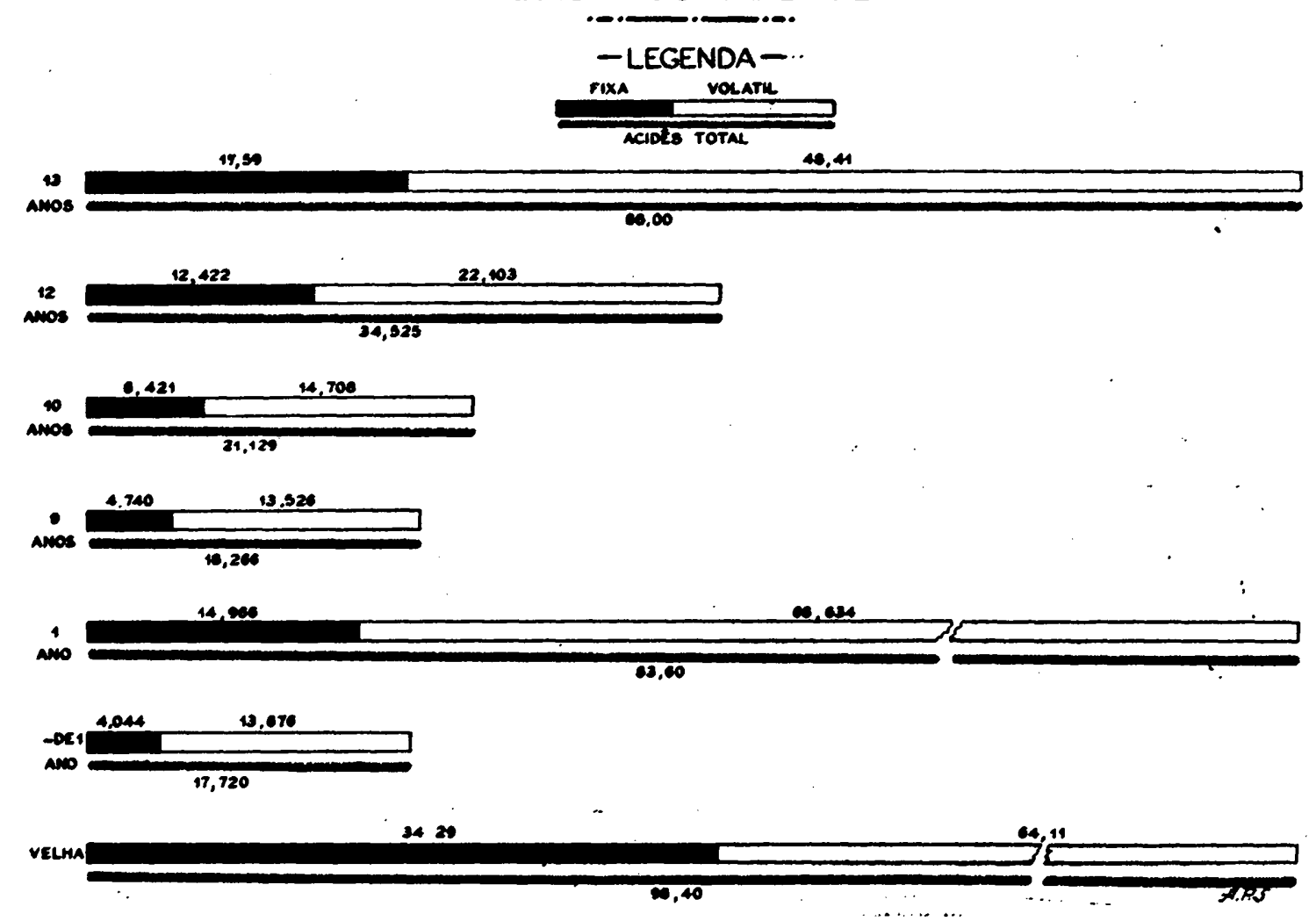


A despelto das variaçбes individuais, fruto da diversidade do sisiema de conservaça ou de tamponamento, nota-se perfeitamente 0 acréscimo da acides durante 0 envelhecimento. Com o fim de ressaltiar essa influencia do envelhecimento no aumentc da acides, basta observarmos as medias das amostras, por ordem de idade :

Idade miligramas de ácido acetico \% Acides total Fixa. Volátil

13 66,000 17,590

12 anos .................. 34,525 12,422 48,410

10 snos

21,129

6,421 22,103

9 anus . . . . . . . . . . . . 18,266

4,740 14,708

1 ano $\ldots \ldots \ldots \ldots \ldots \ldots \ldots \ldots . .8 \%, 8,600$

menos de 1 ano ............ 17,720

14,966 13,526

Velha

98,400

4,044

68,634

13,676

34,290

64,110

C grafịco VI permite, a um rápido exame visual, observar como é marcarte a influéncia do envelhecimento no aumento do te.or de acides das aguardentes. De outro lado, curioso observar também, que sempre a acides fixa é menor que a volátll.

No prupo das aguardentes de 1 ano, correspondentes as amostras de numeros 36,37 e 38 , os valores individual te medio, foram bem elevados, o que só pode ser explicado pela maneira artificial de tratamento a que foram submetidas. $O$ extrate de carvalho sendo multo rico em ácido tánico e substanclas tanoides, conferiu a amostra 36, uma acides mais elevada que qua!quer das medias anteriormente citadas de aguardentes conservadas durante longos anos, apesar de ter apenas 1 ano de isinde.

\section{7 - HSTERES}

Pelo anvelhecimento as aguardentes adquirem um aroma todo especial multo agradável em consequencia da forpaçắo de esteres que sáo mais ou menos aromáticos, dada a sua malor ou menor volatilidade.

ce menos voláteis săo constituidos principalmente por caprilatos ce etiln, de propilo, de iso-propllo e de butilo, bem como por traços de sisteres terpenicos. 0 seu ponto de ebullę̧o varia de $1: 0$ a $180^{\circ} \mathrm{C}$. 
Os muls voiátels, que fervem nas visinhanças de $130^{\circ} \mathrm{C}$, são principalmente acetatos, propionatos e butiratos de etllo, de proplln e de amilo. sto produtos secundários da fermentagho, variando stia natureza e proporçăo com a raça da levedura empregada, com a composiçăo do mosto e outros fatores de menor importancia.

h semelhança do que se dá com o vinho de uva, no envelhecimenito das aguarientes as matérias tanicas também exercem notâvol papel na formaçzo do seu "bouquet". Oxidando-se lentamente a matéria tanica formam-se produtos aromáticos de variável intensidade que adicionados aos ésteres vao dar 0 "búquet", melhorando a qualidade comercial da aguardente. Tanto isso é verdade, que se conservarmos as aguardentes em recipientes que dificultem ou impeçam tais fenomenos de envelhecirento, a aguardente nunca adquirirá as mesmas qualidades apos, envelhecimento, que se fassem conservadas em vasilhaine de carvalho.

t poi isso que se afirma que os ésteres sáo as principais fatores do aroma ou "bouquet", sendo tanto mais abundantes quanto mals velha e de melhor qualidade for a aguardente.

C. aumento natural da acidés verificada pela prolongada consalvaça da aguardente $e$ um fator que ajuda a eterificaçấ, pois já sabemos que o éster é originado da reaçăo entre um álcocl e um ácido. Assim sendo, so podemos concluir pelo aumento de ésteres durante a conservaçáo, isto é, à medida que aumenta a acidés, cresce também o teor em ésteres.

Esta e, sem dư!da uma das razbes por que nos alcobis industriais a quantidade de ésteres é pequena, pois a legislaça. brasileira, pelo menos, limita a acides dos alcobis industriais a 30 miligramas de acido acettico por litro. Fica, assim, tambem, limitada a eterificagto

os eremplos constantes do quadro adeante, originais dos autores, esclarecem bem o que acabamos de afirinar. 


\section{QUADRO X}

\section{Composiçăo dos alcobis industriais}

\begin{tabular}{|c|c|c|c|}
\hline $\begin{array}{c}\text { N.o da amos- } \\
\text { tra }\end{array}$ & Natureza das amostras & $\begin{array}{l}\text { Aoldes total } \\
\text { em mmgre. } \\
\text { de foldo } \\
\text { acétioo \% }\end{array}$ & $\begin{array}{c}\text { Esteres ox } \\
\text { mmgrs. po } \\
100\end{array}$ \\
\hline $\begin{array}{r}1 \\
2 \\
3 \\
4 \\
5 \\
6 \\
7 \\
8 \\
8 \\
10 \\
11 \\
12 \\
\end{array}$ & 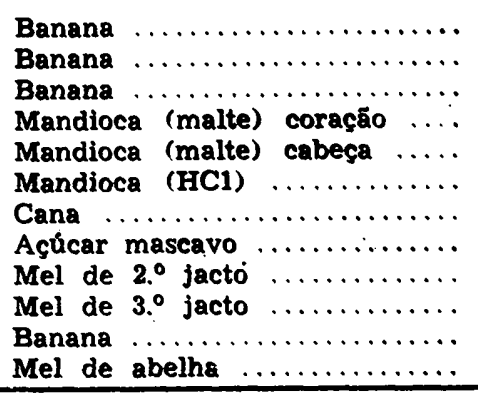 & $\begin{array}{r}12,0 \\
12,0 \\
10,8 \\
7,8 \\
9,4 \\
3,0 \\
4,4 \\
3,4 \\
2,8 \\
1,8 \\
6,8 \\
3,0 \\
\end{array}$ & $\begin{array}{r}35,20 \\
51,04 \\
22,88 \\
8,80 \\
10,56 \\
15,84 \\
16,32 \\
14,08 \\
13,20 \\
7,04 \\
15,84 \\
19,36 \\
\end{array}$ \\
\hline $\begin{array}{l}13 \\
14 \\
15 \\
16\end{array}$ & $\begin{array}{l}\text { Poulenc Freres (Frances) } \ldots \ldots \\
\text { Constantino Matheus } \ldots \ldots \ldots \ldots \\
\text { Milho } \ldots \ldots \ldots \ldots \ldots \ldots \ldots \ldots \ldots \\
\text { Desnaturado } \ldots \ldots \ldots \ldots \ldots \ldots\end{array}$ & $\begin{array}{l}3,6 \\
1,76 \\
1,4 \\
-\end{array}$ & $\begin{array}{r}12,88 \\
9,89 \\
7,04 \\
- \\
\end{array}$ \\
\hline
\end{tabular}

Ya determinaçăo dos ésteres, os autores seguiram o seguinte mótodo analítico: sobre os $50 \mathrm{cc}$. de aguardente que servi־am para a determinaçáo da acidés total, agregam-se 20 cc. de $\mathrm{KOH}$ ou de $\mathrm{NaOH} \mathrm{n} / 10$ e alguns granulos de pedra pomes.

Ferve-se durante uma hora com condensador de refluxo.

Resfria-se e juntam-se $20 \mathrm{cc}$. de H2SO4 n/10, titulando-se a seguir com $\mathrm{KOH}$ ou $\mathrm{NaOH} \mathrm{n} / 10$.

Calcula-se a quantidade de ésteres como acetato de etillo, multiplicando-se o número de $\mathrm{cc}$. de $\mathrm{KOH} \mathrm{n} / 10$, gasto na titula.săo dos $2 n$ cc. de H2SO4 n/10 por 17,6. Tem-se assim os millizramos de éter acético por $100 \mathrm{cc}$. de aguardente.

Fara se calcular a quantidade de ésteres no álcool considerado anidro miltiplica-se o resultado antérior por 100 e divi:ie-se pela graduaç̧o alcoblica da aguardente em exame. $\cdots: \cdots$ 
Os recultados obtidos, constam do quadro seguinte:

\section{QUADRO XI}

\section{Riqueza em ésteres das aguardentes}

\begin{tabular}{|c|c|c|c|c|c|c|}
\hline $\begin{array}{l}\text { N.e da } \\
\text { amestre }\end{array}$ & Fm $\underset{\%}{\operatorname{mmgrm}}$ & $\begin{array}{c}\text { Em mmgra. } \\
\text { por } 1100 \text { de } \\
\text { aloool }\end{array}$ & $\int_{\text {tra }}^{\text {N.o de amos- }}$ & $\mathbf{E m}$ & $\underset{\%}{\operatorname{mmgrs}}$ & $\begin{array}{c}\text { Em mmgrs. } \\
\text { por } 100 \text { de } \\
\text { alcool }\end{array}$ \\
\hline $\begin{array}{l}1 \\
2 \\
3 \\
1\end{array}$ & $\begin{array}{r}149,60 \\
100,88 \\
89,04 \\
106,64\end{array}$ & $\begin{array}{l}401,53 \\
290,30 \\
256,22 \\
298,93\end{array}$ & $\begin{array}{l}24 \\
26 \\
26 \\
27\end{array}$ & & $\begin{array}{l}51,12 \\
52,88 \\
54,08 \\
46,32\end{array}$ & $\begin{array}{l}127.29 \\
131,67 \\
133.82 \\
115.51\end{array}$ \\
\hline Median & 111,54 & 311.845 & $\begin{array}{l}28 \\
29\end{array}$ & $i$ & $\begin{array}{l}22,00 \\
34,64\end{array}$ & $\begin{array}{l}50,22 \\
78,16\end{array}$ \\
\hline$\overline{5}$ & $\begin{array}{r}80,92 \\
124,96\end{array}$ & $\begin{array}{l}174,46 \\
297,17\end{array}$ & Mêdias & & $\begin{array}{l}34,64 \\
56,865 \\
\end{array}$ & $\begin{array}{r}78,16 \\
143,541\end{array}$ \\
\hline 7 & 116,16 & 278,06 & 30 & 1 & 47,44 & 106.77 \\
\hline 8 & 73,87 & 197,64 & 31 & & 40,36 & 90,37 \\
\hline$\theta$ & 163,36 & 414,19 & 32 & & 40,12 & 90,40 \\
\hline 10 & 154,36 & 424,53 & 33 & & 64. & 139.83 \\
\hline 11 & 154,36 & 427.94 & 34 & & 50.72 & 106,42 \\
\hline 12 & 148,28 & 403,46 & 35 & & 37.92 & 91,70 \\
\hline Médias & 127,036 & 326.555 & Médias & & 46.80 & 104,250 \\
\hline 13 & 75,84 & $1 \overline{82}, 83$ & 36 & & $\overline{36,46}$ & 69.54 \\
\hline 14 & 75,84 & 172,65 & 37 & & - & - \\
\hline 15 & 96,32 & 229,06 & 38 & & - & - \\
\hline 16 & 69,88 & 191,70 & Medias & & 36,46 & 69,54 \\
\hline 17 & 40,48 & 110,93 & 39 & & 35,20 & 65,80 \\
\hline 18 & 51,12 & 147,44 & 40 & & 36,96 & 69,09 \\
\hline 10 & 62,88 & 168,57 & 41 & & 38,86 & 74,48 \\
\hline 20 & 37,60 & 102,64 & 42 & & 39,38 & 75,10 \\
\hline 21 & 24,64 & 239,96 & 43 & & 75,65 & 145,53 \\
\hline 22 & 41,12 & 99,46 & Médias & & 45,23 & 85.89 \\
\hline 28 & 59,82 & 157,34 & Velha & & 142,56 & 389.189 \\
\hline
\end{tabular}

Examinando-se estes dados, bem como o gráfico respectivo com éies corstruldo, verifica-se, de fato, que pelo enveinecimentc houve enriquecimento de ésteres. As médias são maịs ampresilvas e assim se alinham : 


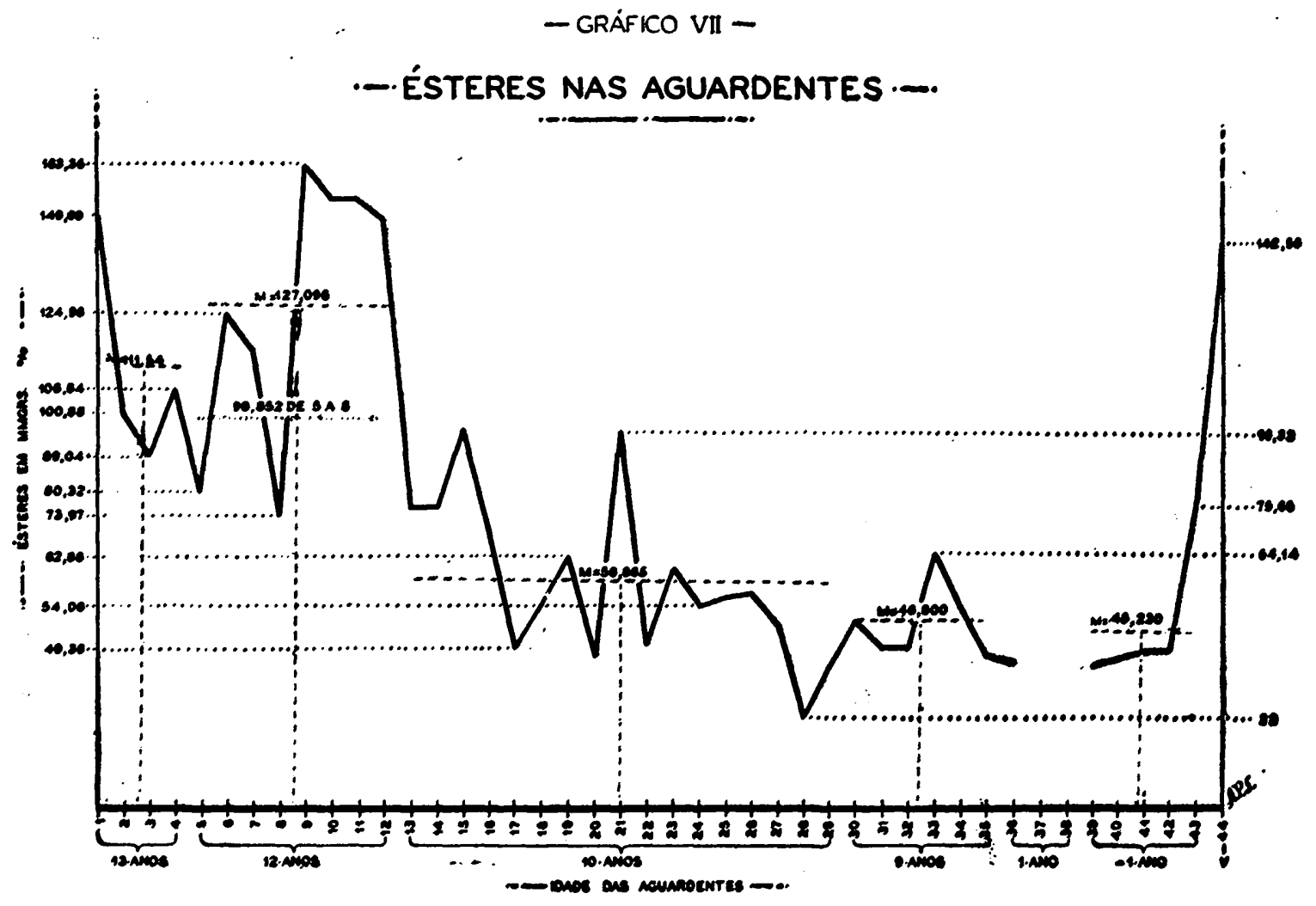




\section{wsteres em}

Jdades

mmgrs. \% mmgrs. por 100 déáleoci

13 anos $\ldots \ldots \ldots \ldots \ldots \ldots \ldots \ldots$
12 anos $\ldots \ldots \ldots \ldots \ldots \ldots \ldots \ldots$
10 anos $\ldots \ldots \ldots \ldots \ldots \ldots \ldots \ldots$
9 anos $\ldots \ldots \ldots \ldots \ldots \ldots \ldots \ldots$
1 anos $\ldots \ldots \ldots \ldots \ldots \ldots \ldots$

menns de 1 ano $\ldots \ldots \ldots . \quad 45,230$

$\begin{array}{rr}111,540 & 311,845 \\ 127,086 & 326,555 \\ 56,865 & 143,54 t \\ 46,800 & 104,250 \\ 36,460 & 69,540 \\ 45,230 & 85,990 \\ 142,500 & 389,189\end{array}$

Nas amostras correspondentes ao grupo de 12 anos, a média fol milor que a acusada pelas amostras de 13 anos. Isto s? expllca porque estäo incluidas naquele grupo, 4 amostras (i: aguai iente de pera, ricas em acidos e, consequentemente. d? esteres. S: nos nos abstivermos destas 1 amostras, a modla para as restantes seria de 99 miligramos de ésteres \% ao invés de 139, em numeros inteiros.

A amostra 36 apresentou um resultado que, embora esperado. nko désxa de ser notável. Apesar de acusar uma elevadi riqueza ers ácido acético \%, deu minimo teor em csteres, o que prova que năo houve eterificaçáo e que o mascaramento do envelhecinento pela adiça de extrato de carvalho pode per.. feltainente ser constatado. confrontando-se estes 2 element.js - aviles e esteres.

- interessante notar tambeni, a influencia do arejamento na formaçấo de esteres. A aguardente 40, depols de convenientemente tratada foi arejada dando a amostra 41 , que de novn arejada e completado 0 tratamento, produsiu a amostra 42. Pols bem : o aumento da acides e de ésteres seguiu nesta mestra ordem. Conclui-se dal, que o arejamento causando uma intena oxigęraça e posterior oxidaçá na aguardente, provocou um aumento rápido de esteres $e$, consequentemente, modificou par? melhor os caracteres organolepticos das aguardentes.

His discordencias havidas entre as diferentes aguardente: da nissma Idade, talvez sejam devidas a saponificaça parcial dos esteres majs aromáticos durante a distilaço. De fato, cabe-se qui em virtude de uma temperatura elevada em melo muito ácilo como sói ser o vinho, quase sempre da-se a saponificacllo parcial dos esteres. Neste caso sto arrastados junto com os vapores hidroalcoblicos apenas os esteres menos volktels e, portanto mals estáveis. Como consequencia a análise val revelar uma riqueza bem menor de isteres. 
Thlvez seja esta a causa por que as amostras $3,5,8,20,28$ e 29, acusaram. dentro de cada série respectiva, menor teor de ésterı s que as demala.

Cra. como vimos antes e, realmente, sendo os ésteres fatores de qualidade, para evitar esta possivel saponificacto prejudicial of que aconselhamos na distilaça dos vinhos de frutas para Jbtençă das aguardentes, além das condigbes basicas que presidem as operaçøes distilatórias, mais as duas seguintes:

a - coa* muito bem o vinho para livra-lo de substancias em suspensac que possam contribuir indiretamente para a e'evaçáco do ponto de ebuliçăo;

b - reuitralizar, pelo menos parcialmente 0 vinho a ser distilado.

\section{8 - ALCOGIS SUPERIORES}

Nas aguaruentes a presença dos alcoóis superiores e fato absolutarnente normal e sua proporçăo, por via de regra, é elevacia, io contrário do que se dá nos alcobis industriais bem retificadcs. Raramente a proporçáo dos alcobis superiores é inferi.r. \& 100 mmgrs., podendo atingir e mesmo ultrapassar 800 mingrs.

Como a separação do óleo fúzel se faz nas colunas de retificzạan, se ests fơr n:al feita, ipso fato, o álcool acusará elevada percentagt.m de alcobis superiores, pois sáo estes que formar. o bleo fízel. A reciproca tambem é verdadeira.

Compare-se, por exemplo, os resultados obtidos pelos autores; em sicoois preparados em pequena coluna Esteve de laboratório, onde năo se faz a separaçáo dos oleos leves e pesados, com alcosis industriais do comércio, bem retificados:

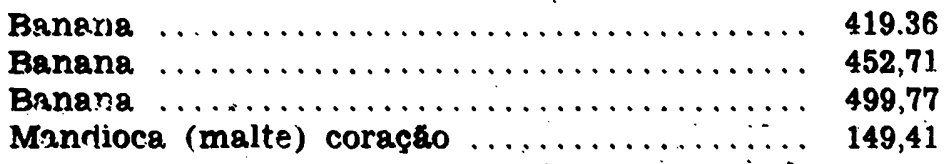

Pculenc Freres (Frances) $\ldots \ldots \ldots \ldots \ldots \ldots, \ldots, 13,87$

Constantino Matheus $\ldots \ldots \ldots \ldots \ldots \ldots \ldots \ldots \ldots, 14,62$

Milhn ... ....................... 12,49

Pur ser a aguardente fabricada em alambiques quase sempre sem retificadores e, consequentemente, sem separaçăo do oleo fizel, a sua riqueza em alcobis superiores quase sempre 
muitc elfvada Naturalmente que se o distllador for bastante prático e caprichoso e aproveitar apenas o produto de coraçăo e, quando muito o de coraçăo e de cabeça, a quantidade de alcoöis superiores é menor, pois eles se acumulam nos produtos de cauda que começam a passar quando o alcoometro começa a nıarcar 45 a $50^{\circ}$ G.L.

as alcobls superiores năo se alteram muito com a idade, crescendo a sua proporçlo mais por via indireta, em consequensia ta diminuiçáo do grau alcoblico da aguardente durante a sua conservaçăo.

Ehroneamente, pelo menos assim nos parece, no Brasil consideram impróprias ao consumo as aguardentes que acusarem uma proporçáo de alcoóis superiores acima de $\mathbf{3 3 0}$ mmgrs. Dor litro.

Por muito tempo e até hoje se admite, embora nzo seja a expro:săo da verdàde, que as aguardentes săo prejudicials saude em consequencia das alcoois superiores que elas encerram. Na obstante, - se tecem louvores aos vinhas de uva que sho mais ricos que aquelas em alcodis superiores.

Nho s20 os alcnobis superiores os responsáveis pelas consequencias funestas do alcoolismo, mas sim a quantidade de álcool etillico ingerida. Se se compararem os efeitos, separadamente e rom quantidades iguais de alcoois superiores como 0 amillico, $O$ iso butilico, o butilico e 0 propllico com o álcool etilico. o caso é diferente, pois é indiscutivel que aqueles sto muit.j mais preiudiciais à saude, pois sáo cerca de 10 vezes mais tóxicos que o álcool ordinário.

Mas náo é o caso que se dá na pratica. $O$ individuo que ingere um copo de aguardente, ingeriu na realidade uma dose cavalar de álcool etilico contra uma dose homeopática de alcobis superiores, se atentarmos que, de fato, mesmo nas aguardentes risis ricas em alcoois superiores, a proporçlo destes é minin:a em relaçăo go volume total.

t praciso portanto ficar bem claro que os efeitos desestrosas do ușo contínuo das aguardentes é funçăo quantitativa e nowo de qualidade.

O método analítico usado pelos autores para a determinaço dos 2. Jco61: superiores fol o colorimétrico de ROCQUES, cujo prir:cipio se funda na coloraça adquirida por aqueles corpos em presença do $\mathrm{H} 2 \mathrm{SO} 4$ concentrado.

A expcuç5o deste método requer a seguinte marcha: 


\section{A - SOLUÇAO PADRAO}

a) - Preparaçăo do ślcool iso-butilico : - Distila-se o alcool iso-butilico, recolhendo-se a fraçáo que passa entre $106,5^{\circ} \mathrm{C}$ e 107,50\%; redistila-se, lentamente, recebendo-se o liquido que passa entre $106,7^{\circ} \mathrm{C}$ e $107,1^{\circ} \mathrm{C}$; este segundo distllado se fracciona pela terceira vez. recolhendo-se o que passa entre $106,8^{\circ} \mathrm{C}$ e $107^{\circ} \mathrm{C}$.

teste o líquicio que vai servir para preparar a soluçăo padrao.

b) - Preparação do álcool puro: - Neutralksa-se exatamente 0 alconl industrial de graduaço minima de $96^{\circ} \mathrm{G}$.L. Junta-se de 1 a $2 \%$ de cloridrato de metafenilendiamina e ferve-se em um balḱn munido de um refrigerante de refluxo, durante 1 hora.

Listila-se, lesprezando-se as primeiras e as ultimas porçóes do cistilado.

O produto de coraçăo assim separado năo deve dar coloraçá com o reativo de Schiff, nem quando misturado em partes iguais com 12504 concentrado, mesmo após fervura a $120^{\circ} \mathrm{C}$ durante 1 hora.

Reduz-se a graduaçăo do alcool exatamente para $66,70^{\circ} \mathrm{G} . \mathrm{L}$. e con ele prepara-se a soluçăo padræ̃o que deve conter 0,667 grs. de álcool iso-butillico por litro de álcool puro a $66,7^{\circ} \mathrm{G} . \mathrm{L}$.

\section{B - PREPARO DA AMOSTRA}

Fm um balăo de fundo redondo de 300 cc., colocam-se 100 cc. da aguardente a examinar, depois de prèviamente distllada e redurida a $50^{\circ} \mathrm{G}$.L.

Cum o fim de fixar os aldeidos, juntam-se cêrca de 2 grs. de cloridratc de metafenilendiamina e alguns fragmentos de pedra pumes e aquece-sc com refrigerante ascendente de modo que o liquido sofra ebuliçáo lenta durante 1 hora. (Pode-se 
substituir o cloridrato por $1 \mathrm{cc}$. de anllina e $1 \mathrm{cc}$. de deido forforicc xaroposo).

Deixu-se esfriar o liquido, substitui-se o refrigerante ascendente por cutro ordinário descendente e distila-se, recothendo-se em frasce graduado, exatamente 75 cc. sote diatilado contem a quantidade total do álcool existente nos 100 cc. do liquido em exame, acusando, por isso, uma graduagtio de $66,7 \circ \mathrm{G}$.L. alcoots supertores.

A quantidade de dicool puro de $90^{\circ}$ C.L. que se deve adiclonar a uma aguardente para deixá-la com 500G.L. é encontrada já calculada na tabela II adeante apresentada.

\section{C - METODO OPERATORIO}

I: liquido distllado e bem homogenelzado tomam-se $10 \mathrm{cc}$. por tuna pipet:ı de 2 traços, passando-se para um baláo aferido de 100 cc., absolutamente seco e limpo.

Em outro balæo de 100 cc., nas mesmas condiçбes, plpetamse 10 cc. da soluçáo padrăo

Em ambos os balరes, juntam-se 10 cc. de H2sot incolor, p. p. anál'se e agitz-se para se obter uma mistura bem homogenea. O H2SO4 forma com as alcobis superiores, por ebulighio, uma colnraçăo amareia.

()s balరes contendo a mistura sulfúrica sáo aquecidos com refrigalante ascendente, a $120^{\circ} \mathrm{C}$, em banho de cloreto de calcio a 69\%, durante nela hora. O nivel do banho preclsa ser mantido constante.

Tima vez resfriados os 2 liquidos, efetua-se a comparaça no cclorimetro: dando ao liquido padrăo uma espessura de $10 \mathrm{~mm}$.

A intensidade da coloraçăo năo proporcional a \% de alcool iso-butllico presente.

Se a intensidade da cor da aguardente a ensaiar difere multh da apresentada pelo padrio, sera necessario fazer uma 
segu: ca leterminaça, diluindo-a convenientemente com uma proporgas determinada de alcool puro de $66,70^{\circ} \mathrm{C} . \mathrm{L}$.

\section{D - CALCULO}

Para maior facllidade de compreensto, suponhamos um exerpplo numérico, admitindo que a aguardente em exame era de $45{ }^{\circ}$ G.I. Para dar-lhe a graduaçáo de 50\% G.L. fol prectio, a cada 100 cc., adiclonal 12,1 cc. de alcool puro de $90^{\circ} \mathrm{C}$. I., obtendo-se um vo!ume total de $111,8 \mathrm{cc}$. de aguardente de 500 G.I.. conforme se pode ver na tabela II.

Nin exame colorimétrico, a coloraçáo obtida fol equivalente à dadu por :uma so'xçáo de álcool iso-butillico de concentra¿o metzde do padráo.

Comc a soluçăo padrăo corresponde a 500 mmgrs. de alcoóis superiores por litro de álcool a 50 G.L., a aguardente em exame, a.justado a $50^{\circ} \mathrm{G} . L$. conterá $250 \mathrm{mmgrs}$. por litro ou 25 mmgrs. F.jr 100 cc. Assim sendo, em 100 cc. de aguardente de 45ํ.L., teremos :

$$
x=\frac{25 \times 111,8}{100}=27,95 \text { mmgrs. }
$$

de alrobis superiores.

Fara se calcular fara $100 \mathrm{cc}$. de álcool anidro contido na aguardente

$$
x=\frac{25 \times 111,8}{45}=62,1 \text { mmgrs. }
$$

de alcools superiores 


\section{TABELA II}

Centimetros cúbicos de b́lcool de 90\%G.L. que so deve adiolonar a 100 cr. de uma aguardente de 30 a 49,90G.L., para delea-la com una graduaçio de sera. I.

\begin{tabular}{|c|c|c|c|c|c|}
\hline $\begin{array}{l}\text { 3radunge } \\
\text { de envar- } \\
\text { donte }\end{array}$ & $\left\{\begin{array}{l}\text { oc de Alcool } \\
\text { de se G. L. } \\
\text { \% adloloner }\end{array}\right.$ & $\begin{array}{c}\text { Volume da } \\
\text { mistura }\end{array}$ & $\begin{array}{l}\text { Graduagio } \\
\text { da aruar- } \\
\text { dente }\end{array}$ & $\begin{array}{l}\text { ce de Slcool } \\
\text { de we G. L. } \\
\text { a nileionar }\end{array}$ & $\begin{array}{c}\text { Volume da } \\
\text { nirtura } \\
.\end{array}$ \\
\hline $\begin{array}{r}90 \\
1 \\
2 \\
3 \\
4 \\
5 \\
6 \\
7 \\
8 \\
8\end{array}$ & $\begin{array}{l}47,7 \\
47,5 \\
47,3 \\
47,1 \\
46,8 \\
46,6 \\
46,4 \\
46,2 \\
45,9 \\
46,6\end{array}$ & $\begin{array}{l}145.9 \\
145,7 \\
145,5 \\
145,3 \\
145 \\
144,8 \\
144,6 \\
144,4 \\
144,2 \\
143.9\end{array}$ & $\begin{array}{r}34 \\
1 \\
2 \\
3 \\
4 \\
5 \\
6 \\
7 \\
8 \\
9\end{array}$ & $\begin{array}{l}38,4 \\
38,1 \\
37,9 \\
37,7 \\
37,5 \\
37,2 \\
37 \\
36,7 \\
38,5 \\
36.3\end{array}$ & $\begin{array}{l}187 \\
186,8 \\
180,6 \\
186,4 \\
186,2 \\
136,9 \\
186,7 \\
186,5 \\
136,3 \\
136,1\end{array}$ \\
\hline $\begin{array}{r}31 \\
1 \\
2 \\
3 \\
4 \\
5 \\
6 \\
7 \\
8 \\
9\end{array}$ & $\begin{array}{l}45,4 \\
45,2 \\
45 \\
44,7 \\
44,5 \\
44,3 \\
4 \\
43,8 \\
43,6 \\
49,4\end{array}$ & $\begin{array}{l}143,7 \\
143,5 \\
143,3 \\
143 \\
142,8 \\
142,6 \\
142,3 \\
142,1 \\
141,9 \\
141,7\end{array}$ & $\begin{array}{r}35 \\
1 \\
2 \\
3 \\
\\
5 \\
6 \\
7 \\
8 \\
9\end{array}$ & $\begin{array}{l}36 \\
35.7 \\
35,5 \\
35,3 \\
35 \\
34,8 \\
34,6 \\
34,3 \\
34 \\
33,8\end{array}$ & $\begin{array}{l}134,8 \\
184,5 \\
134,8 \\
134,1 \\
138,8 \\
133,6 \\
133,4 \\
133,2 \\
138,9 \\
132,7\end{array}$ \\
\hline $\begin{array}{r}32 \\
1 \\
2 \\
3 \\
4 \\
5 \\
6 \\
7 \\
8 \\
9\end{array}$ & $\begin{array}{l}43,1 \\
42,9 \\
42,7 \\
42,5 \\
42,2 \\
42 \\
41,7 \\
41,5 \\
41,2 \\
40,9\end{array}$ & $\begin{array}{l}141,5 \\
141,2 \\
141 \\
140,8 \\
140,6 \\
140,4 \\
140,2 \\
140 \\
139,8 \\
139,5\end{array}$ & $\begin{array}{r}36 \\
1 \\
2 \\
3 \\
3 \\
5 \\
6 \\
7 \\
8 \\
9\end{array}$ & $\begin{array}{l}33,6 \\
33,4 \\
33,1 \\
32,9 \\
32,7 \\
32,4 \\
32,2 \\
32 \\
31,7 \\
31,5\end{array}$ & $\begin{array}{l}18,6 \\
132,3 \\
138 \\
131,8 \\
131,6 \\
131,4 \\
131,2 \\
131 \\
130,7 \\
130,5\end{array}$ \\
\hline $\begin{array}{r}33 \\
1 \\
2 \\
3 \\
4 \\
5 \\
6 \\
7 \\
8 \\
0\end{array}$ & $\begin{array}{l}40.7 \\
40.5 \\
40,8 \\
40 \\
39,8 \\
39,6 \\
39,3 \\
39,1 \\
38,8 \\
2,7\end{array}$ & $\begin{array}{l}139,3 \\
139,1 \\
138,8 \\
138,6 \\
138,4 \\
138,1 \\
137,8 \\
137,7 \\
137,8 \\
137,8\end{array}$ & $\begin{array}{r}37 \\
1 \\
2 \\
3 \\
4 \\
. \quad 3 \\
6 \\
.7 \\
8 \\
9\end{array}$ & $\begin{array}{l}31,3 \\
31 \\
30,7 \\
30,5 \\
30,3 \\
30 \\
29,8 \\
29,6 \\
29,3 \\
29.1\end{array}$ & $\begin{array}{l}190,3 \\
130 \\
190,8 \\
129,6 \\
120,4 \\
120,1 \\
128,9 \\
192,6 \\
328,4 \\
128,2\end{array}$ \\
\hline
\end{tabular}


TABELA II - Continuagio

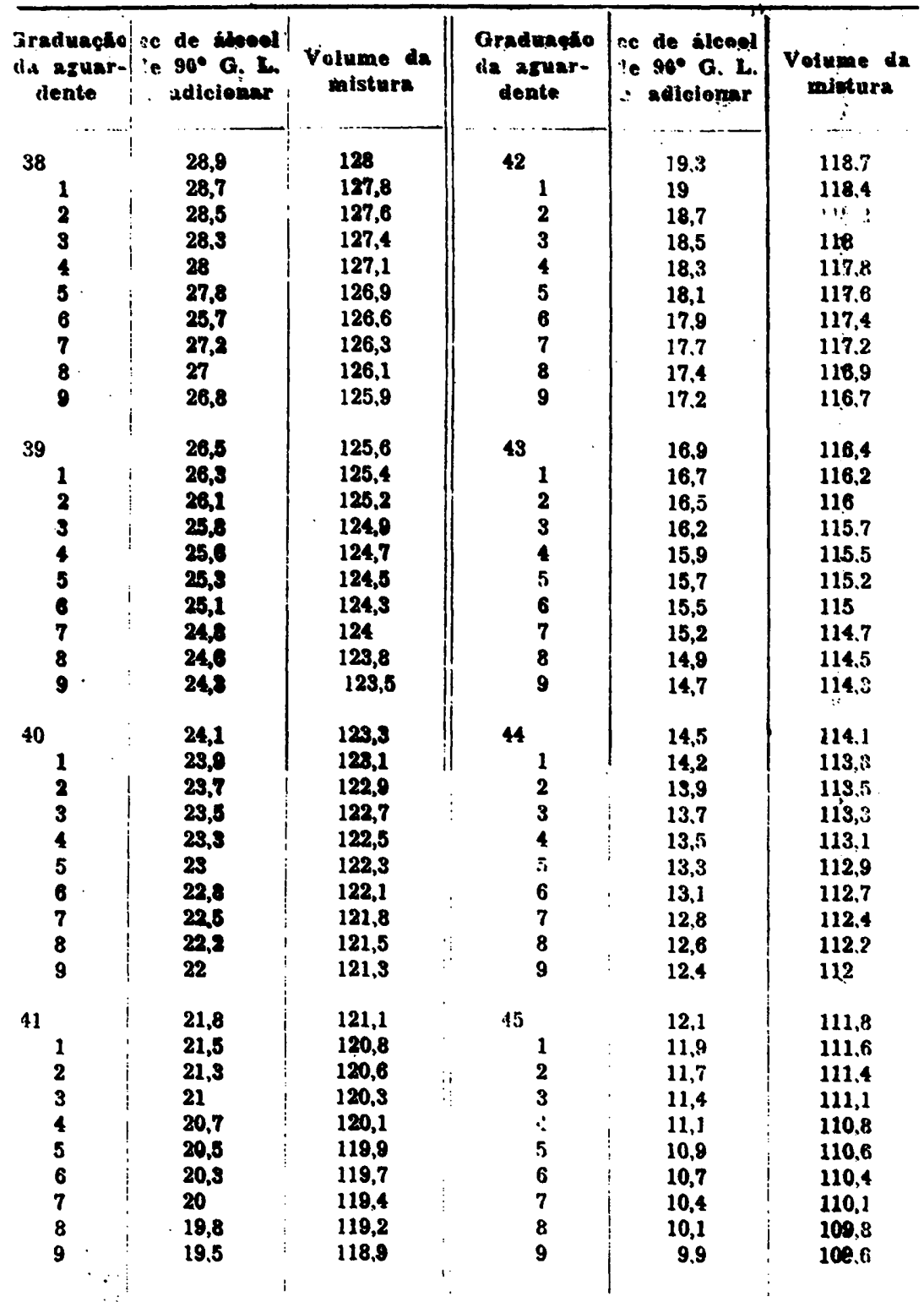


TABRLA H - Condumio

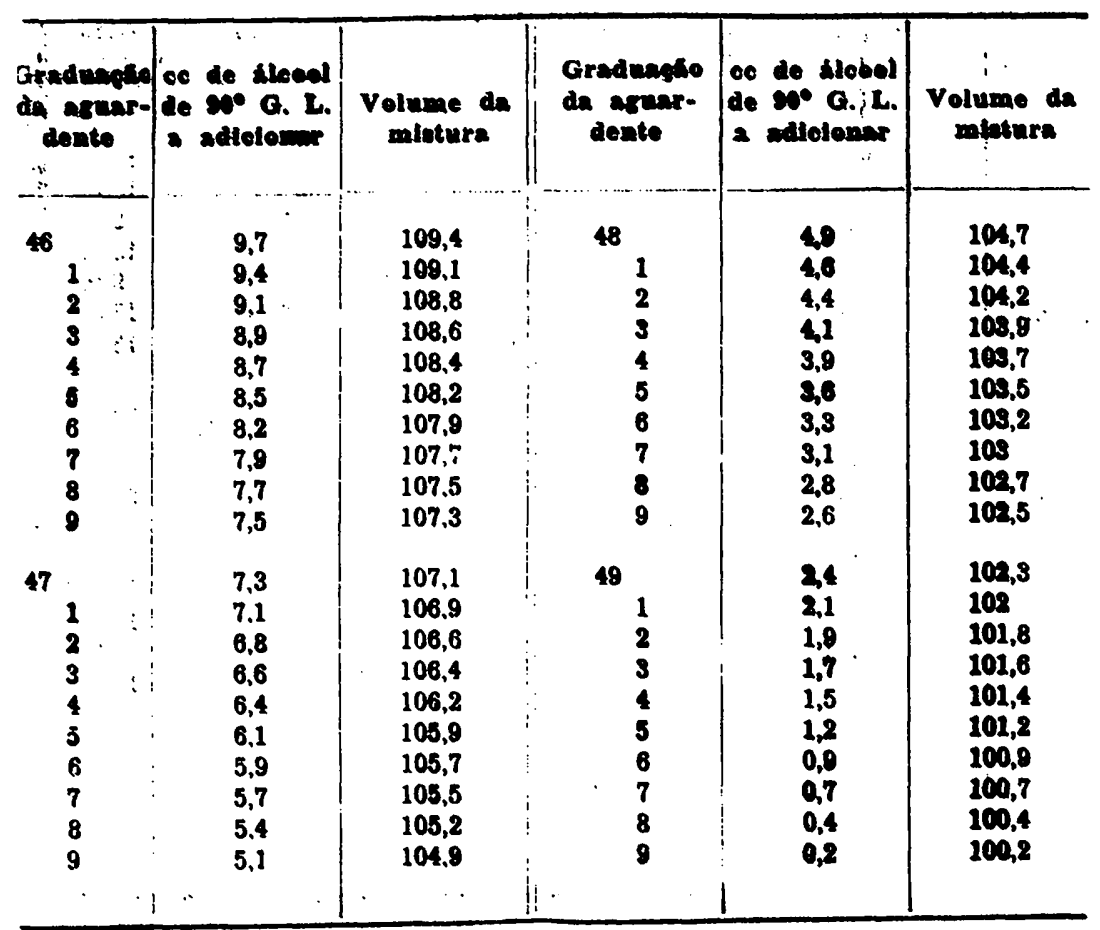

- Paia afuardentes cuja graduaço seja supertor a 8009 t. ussa-se tubela especial, como a Xax apresentada por VurnVBCCIIA.

is recultados obtidos pelos autores calculados em millgramus de alcrols superiores por 100 cc. de Alcool anidro, se encontram no quadro segutnte. 


\section{QUADRO XII}

\section{Alcobis superiores nas aguardentes}

\begin{tabular}{|c|c|c|c|c|c|}
\hline $\begin{array}{l}\text { N.0 da } \\
\text { amostra }\end{array}$ & $\begin{array}{c}\text { Aleools } \\
\text { superiores }\end{array}$ & $\mid \begin{array}{c}\text { N.o da amos- } \\
. \text { tra }\end{array}$ & $\begin{array}{c}\text { Alcools } \\
\text { superiores }\end{array}$ & $\underset{\text { tra }}{\text { N.o da amos- }}$ & $\begin{array}{c}\text { Alocols } \\
\text { muperiores }\end{array}$ \\
\hline $\begin{array}{c}1 \\
2 \\
3 \\
4 \\
\text { Média } \\
5 \\
6 \\
7 \\
8 \\
9 \\
10 \\
11 \\
12 \\
\therefore \\
\text { Média }\end{array}$ & $\begin{array}{l}407,10 \\
289,92 \\
272,94 \\
675,58 \\
\\
411,386 \\
139,70 \\
119,40 \\
285,00 \\
193,86 \\
317,42 \\
416,15 \\
397,52 \\
373,24 \\
\\
280,286\end{array}$ & $\begin{array}{l}13 \\
14 \\
15 \\
16 \\
17 \\
18 \\
19 \\
20 \\
21 \\
22 \\
23 \\
24 \\
25 \\
26 \\
27 \\
28 \\
.29 \\
\\
\text { Média }\end{array}$ & $\begin{array}{l}180,26 \\
196,00 \\
161,62 \\
167,44 \\
137,26 \\
274,43 \\
139,72 \\
143,93 \\
159,80 \\
176,72 \\
273,66 \\
117,41 \\
160,30 \\
439,42 \\
309,53 \\
224,10 \\
130,44 \\
199,178\end{array}$ & $\begin{array}{c}30 \\
31 \\
32 \\
33 \\
34 \\
35 \\
\text { Média } \\
\\
36 \\
37 \\
38 \\
\text { Média } \\
\\
30 \\
40 \\
41 \\
42 \\
43 \\
\text { Média } \\
44\end{array}$ & $\begin{array}{c}185,06 \\
188,37 \\
88,71 \\
180,14 \\
92,00 \\
188,30 \\
138,911 \\
804,00 \\
- \\
- \\
204,00 \\
81,04 \\
127,58 \\
131,20 \\
97,62 \\
131,13 \\
113,714 \\
398,12\end{array}$ \\
\hline
\end{tabular}

Os alcobis superiores normalmente devem acompanhar proporcionalmente ns ésteres numa aguardente de boa qualidade, bem envelhecida. $E$ por isso que se admite que a soma alcools-ésteres, numa aguardente de vinho (conhaque) deve oscllar entre 250 e 350 millgramos por litro, na qual os alcobis superiures raramente sparecem numa proporção menor que 100 milligramos. Quando multo proximo deste limite minimo, porém menor que ele; conclul-se pela pouca idade ou pela qualidade in ferior da aguardente examinada.

Nas aguardentes examinadas aqueles limites acima fixados wo grandemente ultrapassados, como se podera deduzir do simpliss exame dos. dados apresentados pelos autores, parecendo, pir isso, que aqueles limites năo podem ser generalizado" para todas as espécies de aguardentes.

Cra, se é verdade que os alcobis superiores devem acompa. har prnporcionalmente os esteres, resulta que numa aguar- 
denti: de otima qualidade a relaçăo alcoóis/esteres năo deve se afastar muito da unidade, estando entre 1 e 2 . Entretanto. há tijos :muito bons de aguardentes, principalmente nas de uva, que podem chegar e nesmo passar de 3.

Quando a aguartente acusar malor riqueza em alcobis superio"es ci!e de éstores. quase sempre ela resulta de mí preparaçán, consequéncie da composiça defeltuosa do mosís, de fermeritaçoes ancrmals ou infecciosas ou devido a sapninificaça parciai cos ésteres, etc

A. contrério, admite-se como de qualidade inferioi a aguariertite que revelar grande predominancia de ésteres em relàçacc an teór em alccóis superiores, podendo-se concluir também pela zdiçán de essencias onde predominam os esteres cum - fir de mascarar o envelhecimento e melhorar o aroma da aguarcente Neste caso a relaçăo alcoóls/esteres é sempre inferior à unidade.

E presiso, entietanto, năo exagerar estas consideraçós de orden g:ral, aplićaveis principalmente para as aguardentes de uva. Usá-las com parcimonia é sempre bOa politica do anallsta.

Le fato, conforme se poderá ver no quadro seguinte, na:: aguar.jentes examinaars pelos autores, a relaça alcobis/esteres $f r i$ sitisfeita na sua quase totalidade. Os limites extremos oscilaram te 0,4 ate $\mathbf{4 , 4 6}$.

H?uve predominancia de ésteres nas amostras $2,5,6,8,9$, $10,11,12,13,15,16,19,21,24,33,34,43$ e 44 e de alcobis superiores nas demais. Nao obstante, todas foram preparadas de modo idéntaco e nenhuma delas recebeu adiçto de essencias.

Muita. cuntradiçסes que aparecem nestes dados, llustrados pelo jráíico VIII, podem ser devidas a 2 causas principals :

a - vasilhame inadequado para a conservaço das aguardentes, que nzo permitiu que o envelhecimento se processasse en condiçбes normals;

i) - fermentaçoes irregulares, pois as aguardentes em questro, Am grande numero foram preparadas quando estudavamis a questao de rendimento em pinga, aplicando-se - processc du fermentação do mosto pelo sistema "cal"j'rs", de uso generalizado nas nossas engenhocas.

i:s os resultados dos cálculos da relaçáo alcosis/esteres das diferentes apup.rdentes: 


\section{QUADRO XIII}

Relaçro alcodis/esteres nas aguardentes

\begin{tabular}{|c|c|c|c|c|c|}
\hline $\begin{array}{l}N .0^{\circ} \text { da } \\
\text { smontra }\end{array}$ & Relagito & ${ }_{\text {tra }}^{\text {N.o da amos- }}$ & Relaghio & N.o de amos- & Dolacto \\
\hline $\begin{array}{c}1 \\
2 \\
3 \\
4 \\
8 \\
6 \\
7 \\
8 \\
9 \\
10 \\
11 \\
12 \\
13 \\
14 \\
15\end{array}$ & $\begin{array}{r}1,01 \\
0,99 \\
1,60 \\
2,26 \\
0,80 \\
0,40 \\
1,04 \\
0,08 \\
0,76 \\
0,88 \\
0,92 \\
0,92 \\
0,08 \\
1,13 \\
0,70\end{array}$ & $\begin{array}{l}16 \\
17 \\
18 \\
19 \\
20 \\
21 \\
22 \\
23 \\
24 \\
25 \\
26 \\
27 \\
28 \\
29 \\
30\end{array}$ & $\begin{array}{l}0,87 \\
1,23 \\
1,86 \\
0,79 \\
1,40 \\
0,66 \\
1,77 \\
1,74 \\
0,92 \\
1,21 \\
3,28 \\
2,68 \\
4,46 \\
1,67 \\
1,73\end{array}$ & $\begin{array}{l}31 \\
32 \\
33 \\
34 \\
36 \\
36 \\
37 \\
38 \\
39 \\
40 \\
41 \\
42 \\
43 \\
44\end{array}$ & $\begin{array}{c}1,86 \\
1,09 \\
0,09 \\
0,87 \\
1,72 \\
4,37 \\
= \\
- \\
1,29 \\
1,04 \\
1,76 \\
1,06 \\
0,82 \\
0,09\end{array}$ \\
\hline
\end{tabular}

Acreditamos, jelos resultados obtidos, que a despeito da

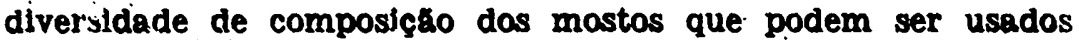
na fabrinaçto das aguardentes, aquela relaçao deve ser observada, pols porie ser obtida quando a aguardente for proventente da distilaca de vinho fermentado normalmente e a conservaça tenha sido felta em vasilhame adequado.

Para efelto coinparativo, estabelecemos, a priori, a seguinte tabela de julgamento, para podermos determinar a qualidade das aquarientes. levando-se em conta tao somente a relaçáo alco.is/ésteres :

$$
\begin{aligned}
& \text { menos de } 0.5 \text { - inferior } \\
& \text { de } 0.5 \text { a } 0,7 \text { - boa } \\
& \text { de } 0,7 \text { a } 0,9 \text { - multo boa } \\
& \text { de } 0,9 \text { a } 1,1 \text { - otima } \\
& \text { de } 1,1 \text { a } 1,3 \text { - muito boa } \\
& \text { de } 1,3 \text { a } 1,5 \text { - boa } \\
& \text { mais de } 1,5 \text { inferlar. }
\end{aligned}
$$




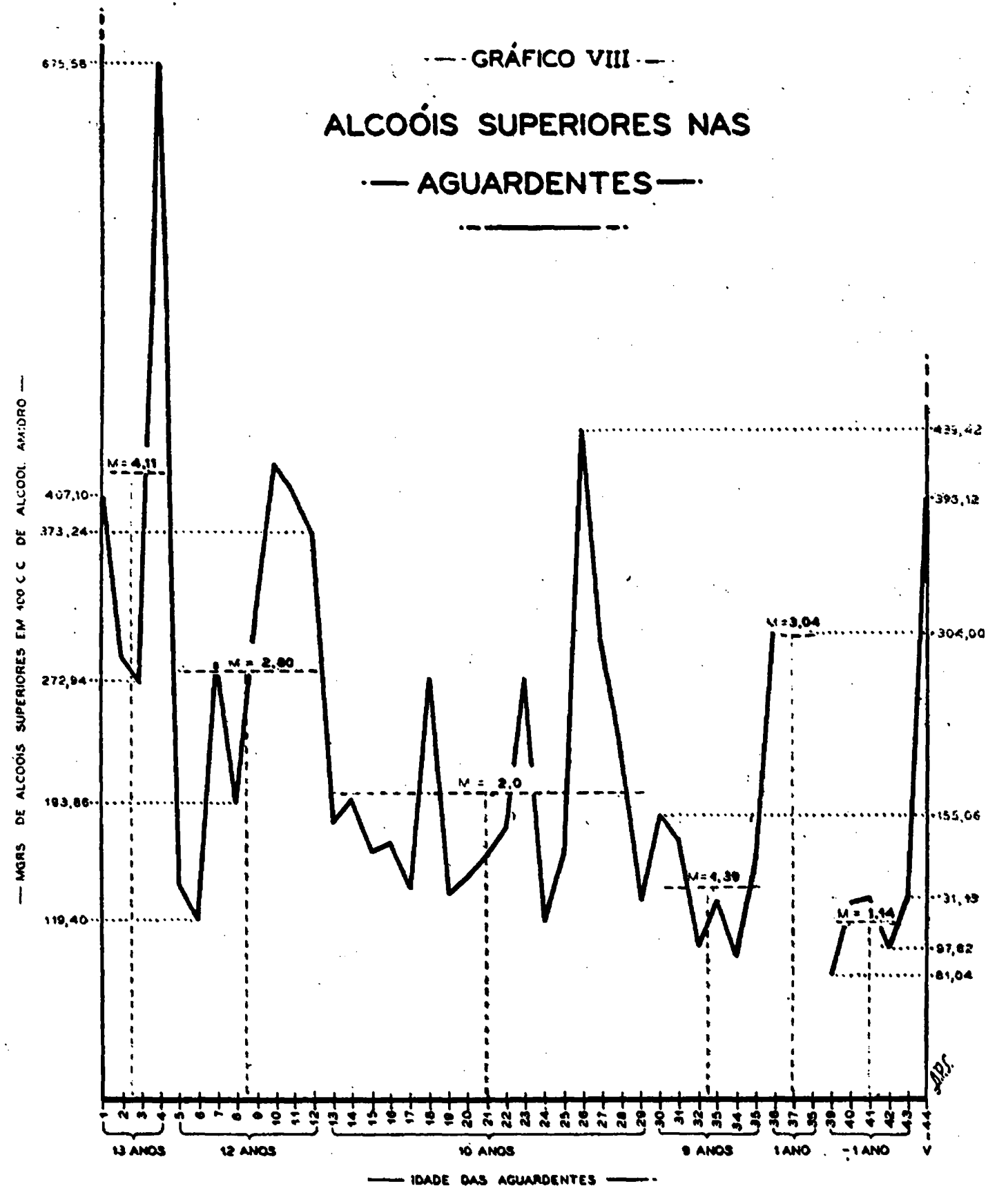


Com esto escala arbitrária de classificaçāo, chegamos aos seguintes resultados.

\section{QUADRO XIV}

Julgamento das aguàrderites pela relighá alcedis/esteres

\begin{tabular}{|c|c|c|c|c|c|}
\hline $\begin{array}{l}\text { N.o da } \\
\text { nemos inn }\end{array}$ & Julsamento & N.o da amos- & Julgamento & $\begin{array}{c}\text { N.o da amoat } \\
\text { tra }\end{array}$ & Julgamento \\
\hline $\begin{array}{l}1 \\
8 \\
5 \\
4 \\
5 \\
6 \\
7 \\
8 \\
8 \\
10 \\
11 \\
12 \\
13 \\
14 \\
15\end{array}$ & $\begin{array}{l}\text { otima } \\
\text { otima } \\
\text { Inferior } \\
\text { Inferior } \\
\text { it!ito boa } \\
\text { Inferior } \\
\text { Otima } \\
\text { otima } \\
\text { inito boa } \\
\text { otima } \\
\text { Stima } \\
\text { itima } \\
\text { Otima } \\
\text { Yt!ito boa } \\
\text { Soa }\end{array}$ & $\begin{array}{l}16 \\
17 \\
18 \\
18 \\
20 \\
21 \\
22 \\
23 \\
24 \\
28 \\
26 \\
27 \\
28 \\
29 \\
30\end{array}$ & $\begin{array}{l}\text { Muito boa } \\
\text { Muito boa } \\
\text { Inferior } \\
\text { Muito boa } \\
\text { Boa } \\
\text { Boa } \\
\text { Inferior } \\
\text { Inferior } \\
\text { Otima } \\
\text { Muito boa } \\
\text { Inferior } \\
\text { Inferior } \\
\text { Inferior } \\
\text { Inferior }\end{array}$ & $\begin{array}{l}31 \\
32 \\
38 \\
4 \\
35 \\
38 \\
37 \\
38 \\
4 \\
40 \\
41 \\
48 \\
43 \\
41\end{array}$ & $\begin{array}{l}\text { Inferior } \\
\text { Otima } \\
\text { Otima } \\
\text { Muito boa } \\
\text { Inferior } \\
\text { Intarior } \\
\text { Muito boa } \\
\text { Inferior } \\
\text { Inferior } \\
\text { Otima } \\
\text { Muito boa } \\
\text { Otima }\end{array}$ \\
\hline
\end{tabular}

\section{9 - AIDEFDOS}

Os aldeicios såo produtos de oxidaçåo simples dos alcoo:s. constitui do produtos intermediarios na formaçăo dos seldos.

A sua proporç8 cresce durante o envelhecimento das aguardentes, embora este aumento nko obedeça qualquer proporcinnalidade com a idade da marma.

Como no caso dos alcobis superiores, os alcobis industriais bem retificados săo muito pobres em aldeidos, ao contrário daTileles ricos de produtos de cabeça, como e o caso da amostra 13, que fol preparada pelos autores, de mandioca sacarificada com malte de milho e separada como primeiro distilado da coluna retificadora Esteve, de laboratorio. 


\section{QUADRO XV}

\section{Aldefilos nos alcodis industrinis}

\begin{tabular}{|c|c|c|c|}
\hline N.o da amos- & CLASSE & $\begin{array}{l}\text { Aldeidos am } \\
\text { mmers. } \%\end{array}$ & $\begin{array}{l}\text { Aldoldos om } \\
100 \text { oc de al- } \\
\text { cool anildro }\end{array}$ \\
\hline $\begin{array}{r}1 \\
2 \\
3 \\
4 \\
5 \\
6 \\
7 \\
8 \\
9 \\
10 \\
11 \\
12 \\
13\end{array}$ & 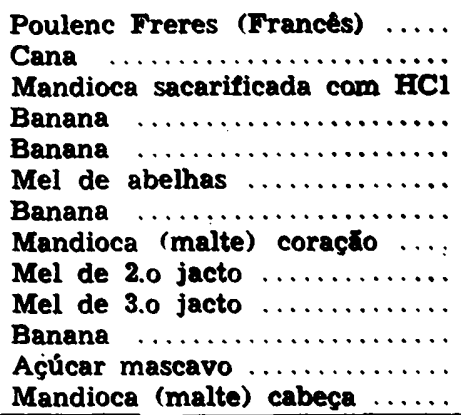 & $\begin{array}{r}1,32 \\
1,76 \\
3,96 \\
11,88 \\
14,52 \\
17,60 \\
19,36 \\
23,32 \\
37,84 \\
44,44 \\
67,32 \\
71,68 \\
135,40\end{array}$ & $\begin{array}{r}1,36 \\
1,9 \\
4,5 \\
13,5 \\
16,4 \\
19,2 \\
21,9 \\
27,2 \\
40,7 \\
48,4 \\
77,2 \\
80,2 \\
156,9\end{array}$ \\
\hline
\end{tabular}

Como já vimos, os principals aldeidos que aparecem nas aguardentes săo o aldeido acético e paraldeldo, 0 aldeido fórmico, o acetal e em pequenas quantidades os aldeidos homologos superiores (butírico, valerianico, caproico), alem de outros como acroleina, furfurol, etc.

Durante a distilaçáo eles se separam como produtos de cabeca, razko pela qual, quanto mais bem felta a retificaçio, tanto mais polkre sorá o alcool destes produtos. A amostre 13 do quadro anterior é um testemunho insoflsmável do que acabamos de afirmar.

Como, pny via de regra, nžo se fas a separaglo dos produtos de cabeca na fabricaça ordinária das aguardentes, estas to sempre ricas em aldeidos.

C método vitilizado para a determinaglo dos aldeidos foi o volumétrico, que exige as seguintes solugbas: 
Solughio : S: :

Sulfito de sódio pp.p.a. e seco $\ldots \ldots \ldots \ldots \ldots \ldots \ldots \ldots \ldots, 12,6$ grs.

Dissolver em : água $\ldots \ldots \ldots \ldots \ldots \ldots \ldots \ldots \ldots \ldots, \mathbf{4 0 0 , 0}$ ec. Adtcionar : H2S04 $n / 1 \ldots \ldots \ldots \ldots \ldots \ldots \ldots \ldots, 100,0$ grs. Alcool a $95^{\circ}$ G.L. ..................... completar a 1.000 cc.

Filtra-se depois de preparada:

\section{Solugino I}

Suluçáo $n / 10$ de lodo em lodeto de potsussio.

Dasta soluçáo, 1 cc. corresponde 20,0022 de aldeido etilico e 0,0032 de $\mathbf{s 0 2}$.

7 itula-se a soluçác $S$ com a solugbio I em presença de goma de amido rncém preparada. Se o sulfito de sodlo empregado for nuro, $10 \mathrm{cc}$. da soluçăo s exigem $20 \mathrm{cc}$. da soluçăo I.

Para doser os aldeidos, introduzem-se em um balso graduado de $100 \mathrm{cc}$ de coln largo, $10 \mathrm{cc}$. da aguardente. Juntam-se $50 \mathrm{cc}$. da soluçăo S. Completa-se o volume de $100 \mathrm{cc}$. com álcool a $50^{\circ} \mathrm{G}$.L. previamente purificado. Tapa-se o balko com rolha de cortiça e agita-se.

Prepara-se um testemunha nas mesmas condiçoes, tomando-se $50 \mathrm{cc}$ da soluçáo $\mathrm{S}$ e completando-se o volume a 100 . cc. com d́lcosl a $50^{\circ}$ G.L. Tapa-se e agita-se.

- is 2 balరes sáo postos em banho-Maria a $50^{\circ} \mathrm{C}$, durante 4 horas

Deix $\lambda$-se esfriar. agita-se novamente e tomam-se $50 \mathrm{~cm}$ de cada balšo, sejaradamente e dosa-se a proporçăo de $\mathrm{S02}$ mediante a soluça I, usando goma de amido como indicador.

Supordo-se que A representa 0 número de cc. da soluçáo I exigido pelos 50 .cc do testemunha, a a numero de cc. exigido pela aguardente que contem a solugho aldeidica, a rique2a. e.m alriefdo por litro de aguardente serh:

$$
(11-a) \times 0,44 \text {. }
$$

is resultados obiidos em miligramos \% e para 100 cc. de álcool anidro 'estro consignados' no quadro abaixo e esquematizado no graflco correspondente. 


\section{QUADRO XVI}

Aldefdos nas acuardentes examinadas

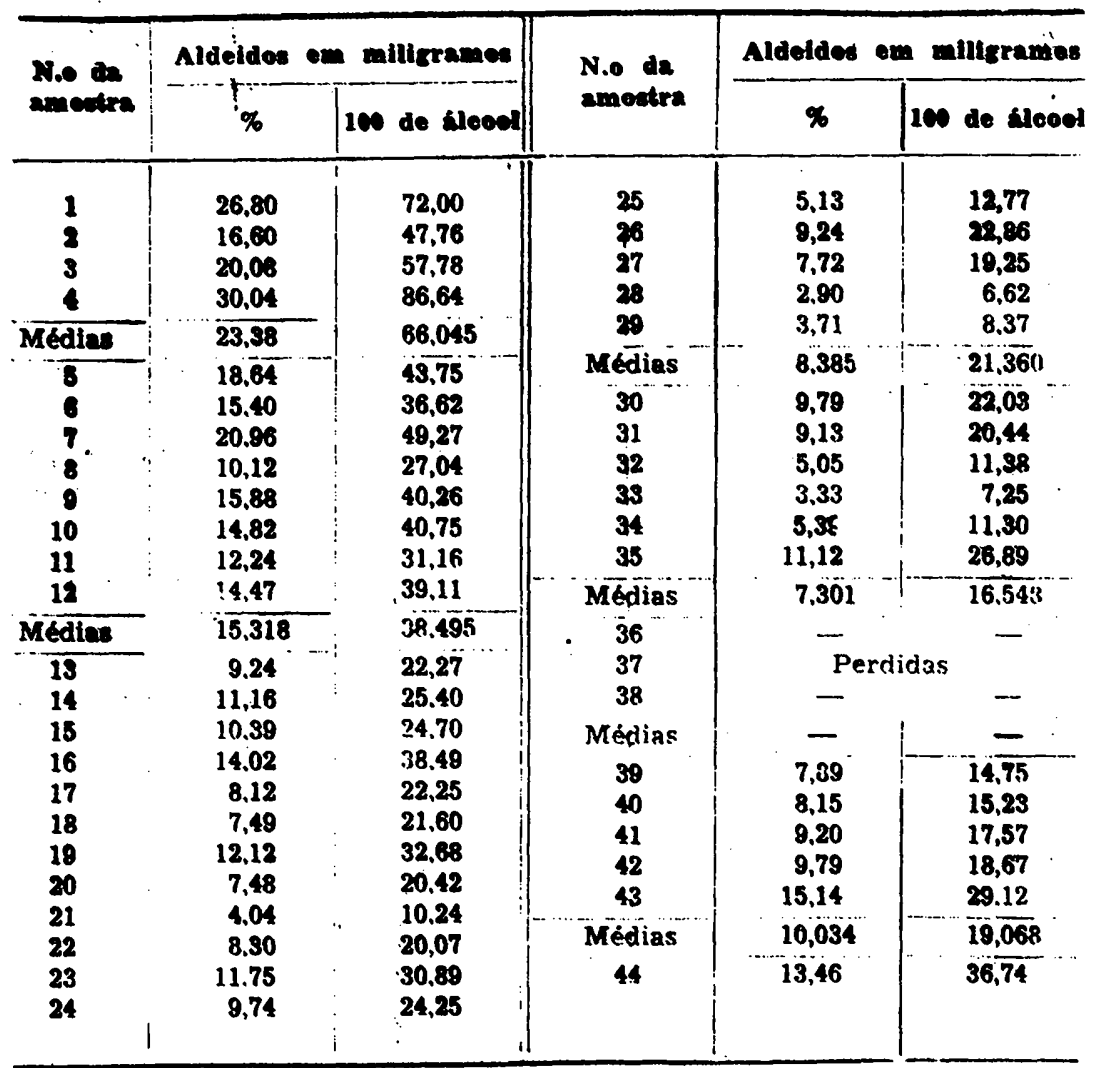

$\Lambda$ despeito das váriaçoes individuals cuja interpretaça nem senipre é fácll, vâlendo-se apenas das médias das aguardentes de cada sérip separadas por ordem de idade, veriflca-se que velo envelhecimento a proporçzo dos aldeidos aumenta.;

- interessante notar, que 0 arejamento favorecendo a axidaço pela grande quantidade de oxigento Incorporada á aguardente pela passagem do ar comprimido atràves da sua masse. parece ter favorecildo a formaça dos aldeidos. A diferença embora nho multo grande 6 bem visivel.

Provavelmente, essa fol a razbo porque a media das aguardentes deste grupo, com menos de 1 ano de conservaça, se apre- 
- GRÁFICO IX - -.

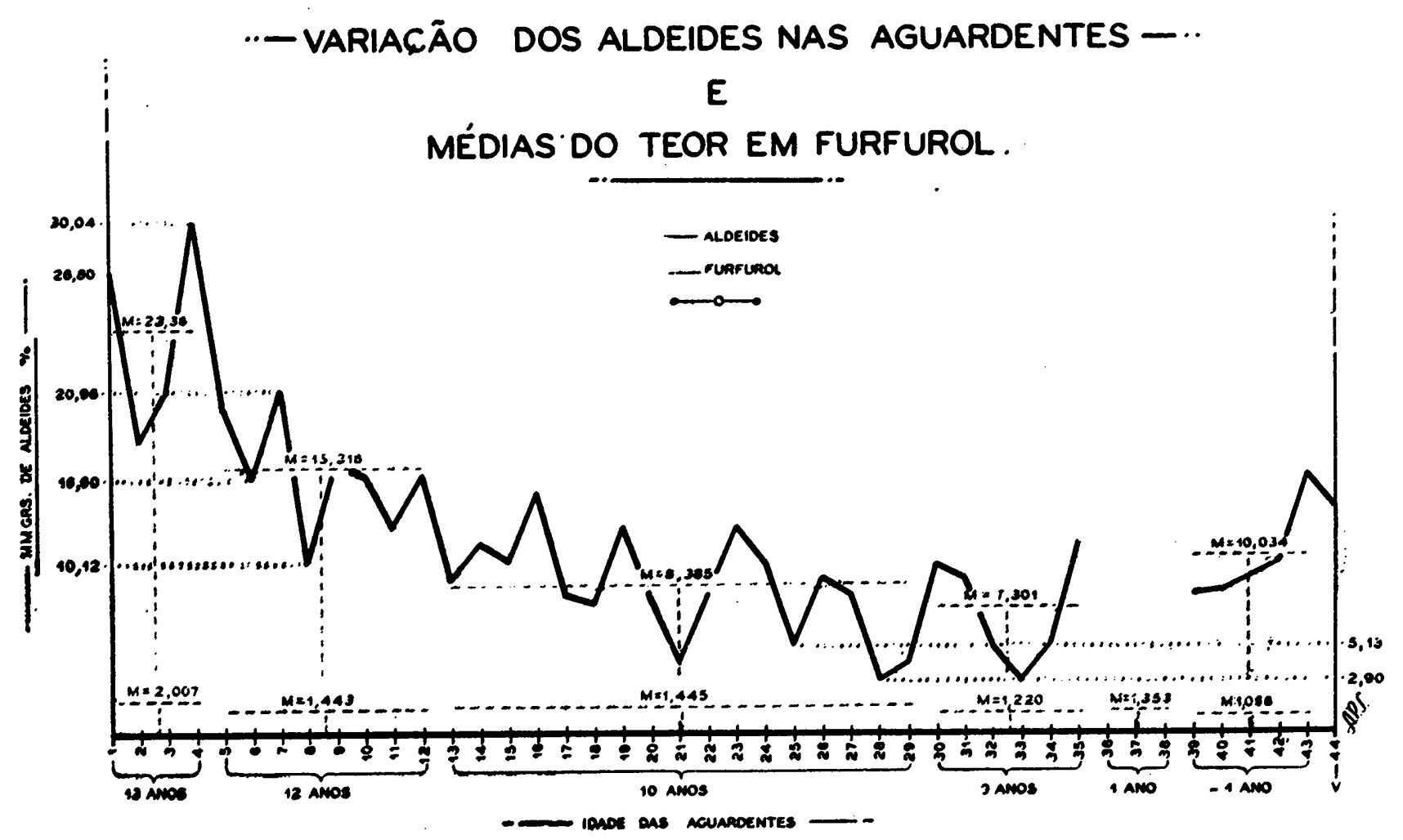


sentou mais elcvada que a do grupo correspondente às aguardentes de 9 anos di: idade.

Ailás, acreditamos que foi essa mesma causa que determinou mainr riqueza em acidés acética das 2 aguardentes arejadas, 1.to e, amostras 41 e 42, que têm a mesma origem na aguardentc 40 .

\section{0 - FURFUROL}

O furfurol resulta da pirogenaçáo das matérias orgánicas depositadas no fundo das caldeiras do aparêlho de distilaçao sendo máxima a sua proporçăo se o aquecimento for feito. fogo direto. Por isso, uma vez que haja cuidado na operaçă de distilaça a idade pouca ou nenhuma influência deve te" sobre a suea proporçăo.

Mintos autores acreditam que o furfurol possa ter sua origem na açác duss ácidos sobre as pentoses ou seus polímeros. que săo assim intensamente hidrolizados, podendo provir, bo consequencia, pelo menos em parte, da madeira dos recipientes usados na conservaçăo das aguardentes.

Uin dos cuidados principais do distilador, para evitar o aumento da furfurol nas aguardentes é distilar um vinho o mais limpo possivel de substancias organicas em suspensăo, principalmente quando este vinho é proveniente de frutas.

f bem possivel que nesta observaçăo se encontre a explicaça p"ra o fato de que as aguardentes de cana, quando obtida da distllaçăo de vinho prèviamente turbinado, săo muito maî: finas e saborosas que se obtidas sem prévia turbinaçăo do vinho. s que neste caso, como acontece no processo de recuperação dás leveduras de Melle, elimina-se do vinho uma grandparte te substáncias sollidas que nêle se achava em suspensăo. Ora, se isso é verdade, com muito maior razão se deve coar muits bem os vinhos de frutas para que se possa fazer a separaçăo dos detritos presentes da matéria prima, pois estes, durante a listilaçăo, assentam no fundo da caldeira, queimam e produzem firfurol que vai impurificar o produto final.

1 quantidade de furfurol náo deve exceder de 20 miligramos vor litro de aguardente.

A determinaçáo do furfurol fol feita colorimètricamente, empragando-se o seguinte método analitico: em um tubo de ensaio graduado, de $10 \mathrm{cc}$., introduzem-se $10 \mathrm{cc}$. da aguardente. previnmente distilada e ajustada a $50^{\circ} \mathrm{G} . \mathrm{L}$; em outro tubo igual, tomam-se $10 \mathrm{cc}$ de um alcool puro, ajustado a 50\%G.L. e que contenha 0,005 grs. de furfurol por litro.

A cada um dos tubos se adicionam 10 gotas de anllina re- 
cem distilada e 1 cc. de ácido acético puro, concentrado e isento de furfurol.

Deix :-se em contacto durante 15 a 20 minutos e comparase a volcraç.̃o dos 2 líquidos no colorímetro.

Q!!ar.do as coloraçర̃es não são iguais, procede-se a uma nova p"sva, tomando menor quantidade de aguardente que dev maic: coloracãc e completando os $10 \mathrm{cc}$. com álcool puro d $50^{\circ}$ G.L., uma vez que a intensidade da coloração não se pode considnrar prororcional à quantidade de furfurol, senăo quando a diferença fôr muito pequena.

com um pouco de prática se consegue, ao fim de 2 a 3 ensaios, obter colorações sensivelmente iguais e comparáveis no colorimetro.

H'zzem-se as leituras das alturas correspondentes aos 2 liquidos, das quais se deduz logo a \% de furfurol na aguardente.

Assin procedendo, obtivemos os resultados que vão abaixo consignatos :

\section{QUADRO XVII}

Furfurol nas aguardentes em mmgrs. por $100 \mathrm{cc}$. de álcool anidro

\begin{tabular}{|c|c|c|c|c|c|}
\hline $\begin{array}{l}\text { N.o da } \\
\text { amostra }\end{array}$ & Furfurol & $\begin{array}{l}\text { N.o da } \\
\text { amostra }\end{array}$ & Furfurol & $\begin{array}{l}\text { N.o da } \\
\text { amostra }\end{array}$ & Furfurol \\
\hline 1 & 0,85 & 13 & 1.41 & 30 & 1,12 \\
\hline 2 & 2,24 & 14 & 1.26 & 31 & 1,11 \\
\hline 3 & 1.47 & 15 & 2.25 & 32 & 1,46 \\
\hline \multirow[t]{2}{*}{4} & 3.47 & 16 & 2.44 & 33 & 0,61 \\
\hline & & 17 & 1.25 & 34 & 1,01 \\
\hline \multirow[t]{2}{*}{ Média } & 2.007 & 18 & 2.55 & 35 & 2,31 \\
\hline & & 19 & 1.25 & & \\
\hline 5 & 1,60 & 20 & 2.30 & Média & 1,220 \\
\hline 6 & 1,62 & 21 & 1.11 & & \\
\hline 7 & 0.79 & 22 & 1.98 & 36 & 0,76 \\
\hline 8 & 1,14 & 2.7 & 1.43 & 37 & 2,13 \\
\hline 9 & 1.23 & 24 & 0.68 & 38 & 1,17 \\
\hline 10 & 1.55 & 25 & 0,81 & & \\
\hline 11 & 1,98 & 26 & 1.02 & Média & 1,353 \\
\hline \multirow[t]{2}{*}{12} & 1,68 & 27 & 1,13 & & \\
\hline & & 28 & 0.98 & 39 & 0,80 \\
\hline \multirow{7}{*}{ Média } & 1,443 & 29 & 0.72. & 40 & 0,84 \\
\hline & & & & 41 & 0.72 \\
\hline & & Média & 1.445 & 42 & 1,35 \\
\hline & & & & 43 & 1,63 \\
\hline & & & & Média & 1,068 \\
\hline & & & & & \\
\hline & & & & 44 & 0,97 \\
\hline
\end{tabular}


Observando-se as resultados obtidos pelos autores, percebe-se bem que a variação do furfurol foi pequena e regular durante o envelhecimento. Nåo obstante, tem-se a impressáo de que o furfurol aumenta com a idade de conservaçáo da aguardente

$\sigma$ resultado verificado com a amostra n..$^{\circ}$, talvez venha em abono dos que admitem que a madeira tem relevante importancia na maior ou menor proporçáo de furfurol presentı numa aguardente.

Nos alcoois industriais a sua percentagem é muito menor. justamente por se tratar de produtos obtidos de vinhos muito mais limpns, mencs densos e, consequentemente, menos susceptiveis de produzir furfurol por pirogenaçáo e, além disso, porque, por via de regra, a distilaçăo se faz com vapor e a conservaçăo se dá em rọcipientes metálicos.

is dadcs abalxo dos autores mostram, para diferentes classes de alcoóis, a percentagem de furfurol, em miligramos, relatịła 20 álccol anidro.

QUADRO XVIII

Furfurol nos alco6is

\begin{tabular}{|c|c|c|}
\hline $\begin{array}{l}\text { N.o da } \\
\text { amostra }\end{array}$ & CLASSE & Furfurol \\
\hline 1 & Banana & 0,56 \\
\hline 2 & Banana & 0,57 \\
\hline 8 & $\ldots \ldots \ldots \ldots \ldots$ & 0,69 \\
\hline 4 & Banana $\ldots \ldots \ldots \ldots$ & 0,56 \\
\hline 5 & Mandioca (malte) coração & 0,34 \\
\hline 6 & Mandioca (malte) cabeça ........... & 0,74 \\
\hline 7 & Mandioca $(\mathrm{HC} 1), \ldots \ldots \ldots \ldots \ldots \ldots$ & 0,28 \\
\hline 8 & Cana $\ldots \ldots \ldots \ldots$ & 0,35 \\
\hline 9 & Açúcar mascavo ..... & 0.25 \\
\hline 10 & Mel de 2.0 jacto & 0.39 \\
\hline 11 & Mel de 3.0 jacto & 0.23 \\
\hline 12 & Mel de abelha. & 0.27 \\
\hline 13 & Poulenc Freres (Francês) & 0,25 \\
\hline 14 & Constantino Matheus \& Cia. ... & $0.5 \hat{i}$ \\
\hline
\end{tabular}

\section{1 - CCEFICIENTE DE IMPUREZAS}

Os caracteres organolépticos que dăo valor comercial às ag̣uardentes săn na sua quase totalidade, devidos ao coeficiente de impurezas ou de compostos secundários que as mesmas aprescntam. Dá a grande importáncia económica e analitica que r.s "r.ão-álcool" apresentam. 
A. impurezas que constituem o chamado coeficiente de impurezas e que representam, por assim dizer, o corpo da aguardent? săo de natureza química diversa, podendo ser grupadas nas siguintes classes principais:

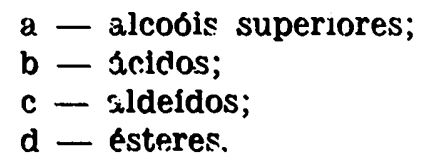

Na primeira classe figuram os alcoois de pêso molecular elevade comr o amílicc, o butílico, o iso-butílico, o propilico, o hexilico, o eptilico e o octílico; na segunda classe destacam-se pela innportáncia, os ácidos voláteis, carbónico, fórmico, acético. buıírico, propriónico, valeriánico, caprónico, caprilico, caprínico, pelurgónico e enántico; na classe dos aldeidos aparecem o etilico. metaldeido. paraldeido, butilico, valérico, furfurol e enânt:co: na última classe predomina o acetato de etilo, além de pequeras quantidades de outros ésteres resultantes da açăc dos acidos e alcoois acima referidos. Ao lado destas impurezas principais, podrm aparecer ainda as bases aromáticas, terpenos, canfinos, ctc.

Fitas impurezas por serem abundantes nas aguardentes. são consileradás produtos normais. Quando a análise química revela unı valor numérico baixo para o coeficiente de impure. zas, pide-se idmitir, com grande probabilidade de acertar, qu se trata de s.lcool industrial bem retificado que foi posterior ment: transformado em aguardente, por hidratação, aromati zaçáo e edulcoramento. E que nos alcoóis industriais, ao contrário dc que se passa com as aguardentes, a proporçăo dos "nãu-álccol" oll imp̣urezas é minima e êsse minimo constitui, sem dúvida, um fator de qualidade. Quanto menor o coeficiente de impurezas mais fino será o álcool em questão.

Nics alcoóis finos, cujos produtos de cabeça e de cauda foram soparados crite:iosamente, o coeficiente de impurezas năo deve pascar de 10 a 20 miligramos, calculado para 100 cc. de álcool arıdro. Nos alcobis ordinários do comércio pode-se admitir até 40 a 50 miligramos. O que passar dai é considerado álcool inferior, de segunda qualidade, mal retificado. Como tais alcoois n⿳亠丷厂 teem quase aldeidos (produtos de cabeça) nem alcobis superiores (produtos de cauda), o pequeno coeficiente de: impurazas é quase que só constituido de ácidos e de ésteres.

() a atores, em allcoóis, por êles preparados encontraram ('s sizujutes resultados para o coeficiente de impurezas, cumpar?tiva'nente com os cie análises compiladas de outros autor $-:$ 


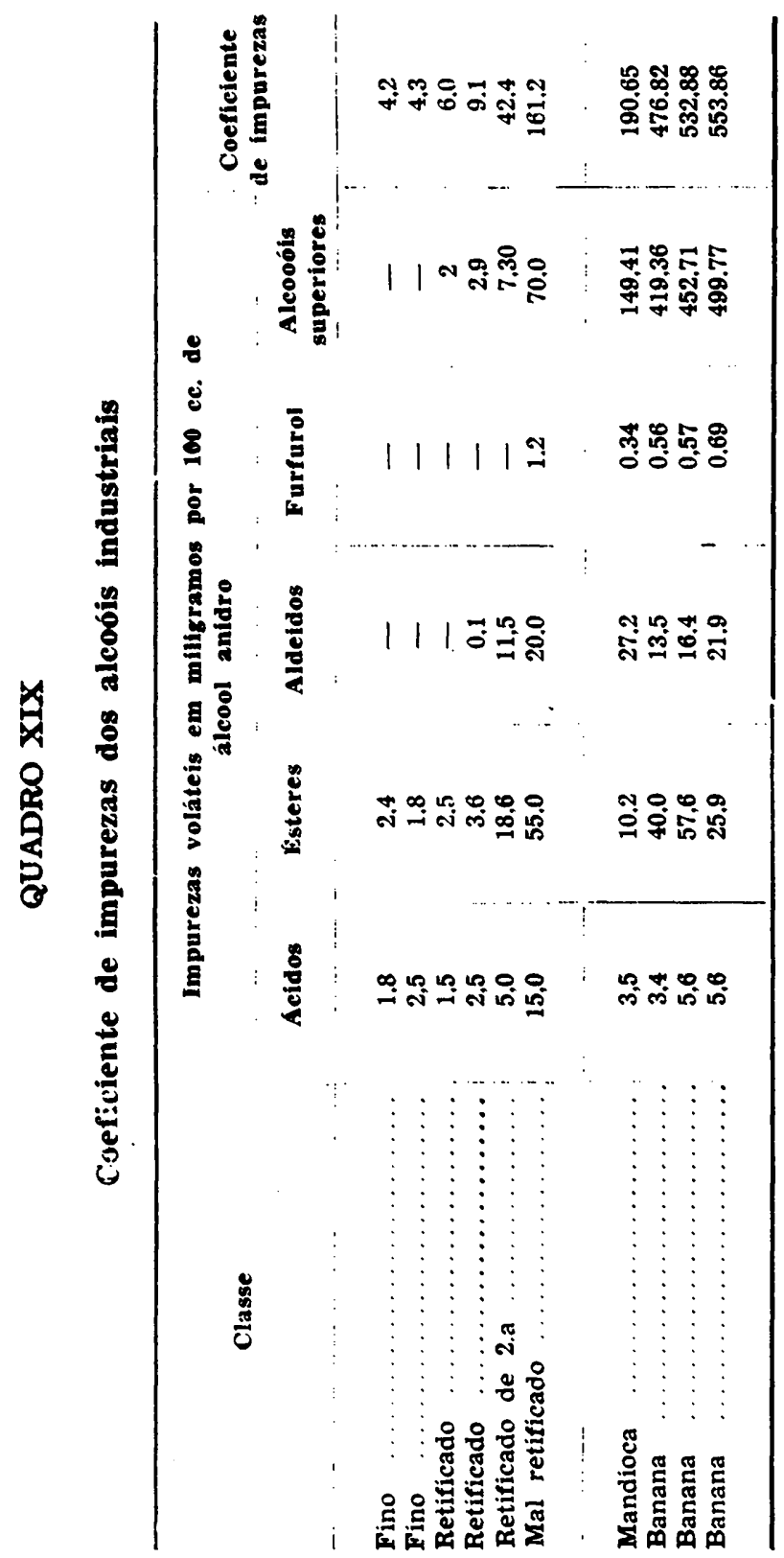


Pela teficiente separação dos produtos de cabeça e nuia separanão dos vrodutos de cauda, os 4 últimos alcoois preparados fr!o- autores nos laboratórios da Luiz de Queiroz, revt,Lim-se com um coeficiente de impurezas por demais elevado, tanto quantro se fossem aguardentes. Ao contrário, nos alcobis finos obtidos na grande indústria êsse coeficiente é de 100 vezes mennr.

Assim proredemos, justamente para salientar o valor da leịiìação na separação dos alcobis industriais. Mesmo em coluna retificadora de laboratório é perfeitamente possivel a on. tençă de alcoóis mais finos. Eastante fazer-se um fraccio. namento converiente do distilado, aproveitando-se tro sòmente o prodintr de coraçãó, constituido pelo álcool de melhor qualidade.

ห. $s$ gguarcientes o coeficiente de impurezas é por demais variárel e dẹpende substancialmente da composição e correçăo do micstr. da p-rfecçáo da fermentaçáo do sistema de distilação dr: vinho e do modo de conservação do produto. Em geral muiti: elrvano, não menos que 200 miligramos, pode atingir até 1.300 niligramos, tendo como termo médio de 500 a 700 mmgrs.

A: ạ̣uardentes de cana dão sempre, em igualdade de condiçörs, un cofficiente de impurezas menor que as obtidas a partị dos melaços lesiduais da fabricação do açúcar de cana.

sir. quadro seguinte damos os resultados obtidos nas análises efetuadas para o cálculo do coeficiente de impurezas das diferentes aguardentes examinadas. 


\section{QLiADRO XX - Coeficiente de impurezas das aguardentes}

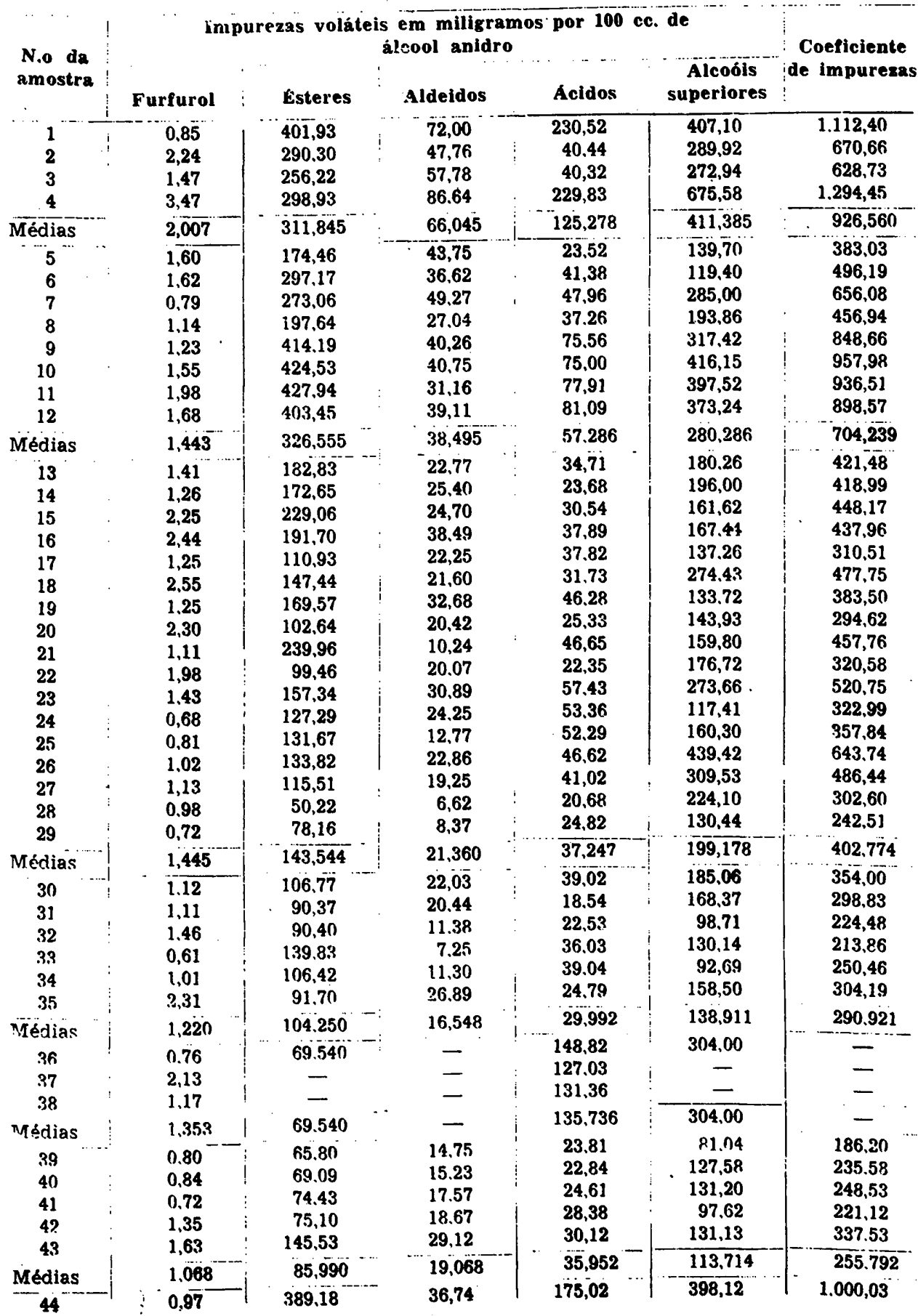


Um exame dêstes dados, bem como do gráfico correspondente. nos mostra claramente que o coeficiente de impurezas foi de frito muito variável, mesmo considerando-se as aguardentes d: mesma espécie e da mesma idade. Isto se explica porqu!e além destas, muitas outras causas existem que fazem variar o coeficiente de impurezas.

Comnarando-se, por idade, verifica-se que o envelhecimento cooperou para o aumento dos "náo-álcool" nas aguardentes ersaiadas:

Idade

Näo-álcool

13 ar.'s

926,560

12 arns

704,239

10 ancis

402,774

9 arius.

290,921

menos

Velha

255,792

$1.000,030$

Em consequência da alta riqueza em ésteres e em alcoóis supericres as aguardentes de pera, correspondentes as amostras te 9 a 1a, acusaram um alto coeficiente de impurezas. Aliás esta é uma das caracteristicas essenciais das aguardentes le frutas Assim. éle varia no Kirsch de 350 a 700; no Quetsch de 270 a 1.200; na de Sidra, de 620 a 850; no conhaque, de 350 a 800 , etc.

Muitos autores admitem que no coeficiente de impurezas das aguardentes de frutas; há uma forte predomináncia de ésteres sobre os alcoóis superiores, pelo que a relaçáo alcobis/ ésteres é sempre inferior à unidade. Este fato encontrou confirmaçăo nos nossos resultados analiticos para as aguardentes de $p \rightarrow r a$.

Jistamente pela importáncia que o corpo de impurezas apresenta, não só no julgamento da qualidade da aguardente como na distincăo dos diferentes tipos e origens, é que se ter. tentado îxar relaçס̄es numéricas entre os principais constituintes das impurezas.

Assim, pur exempio, LUSSON fixa o coeficiente de impurezas eritre $\mathbf{3 5 0}$ a $\mathbf{3 0 0}$ miligramos por litro para as aguardentes de vinho, enquantc que outros autores consideram este valor muito elevado. Aguardente com menor corpo é suspeita de que se trate de produto que fol adicionado de álcool industrial ou ainda de aguardente impropriamente conservada. Todas as aguardento: examinidas satisfizeram esta exigencia. 


$$
\text { - GRÁfICO X - }
$$

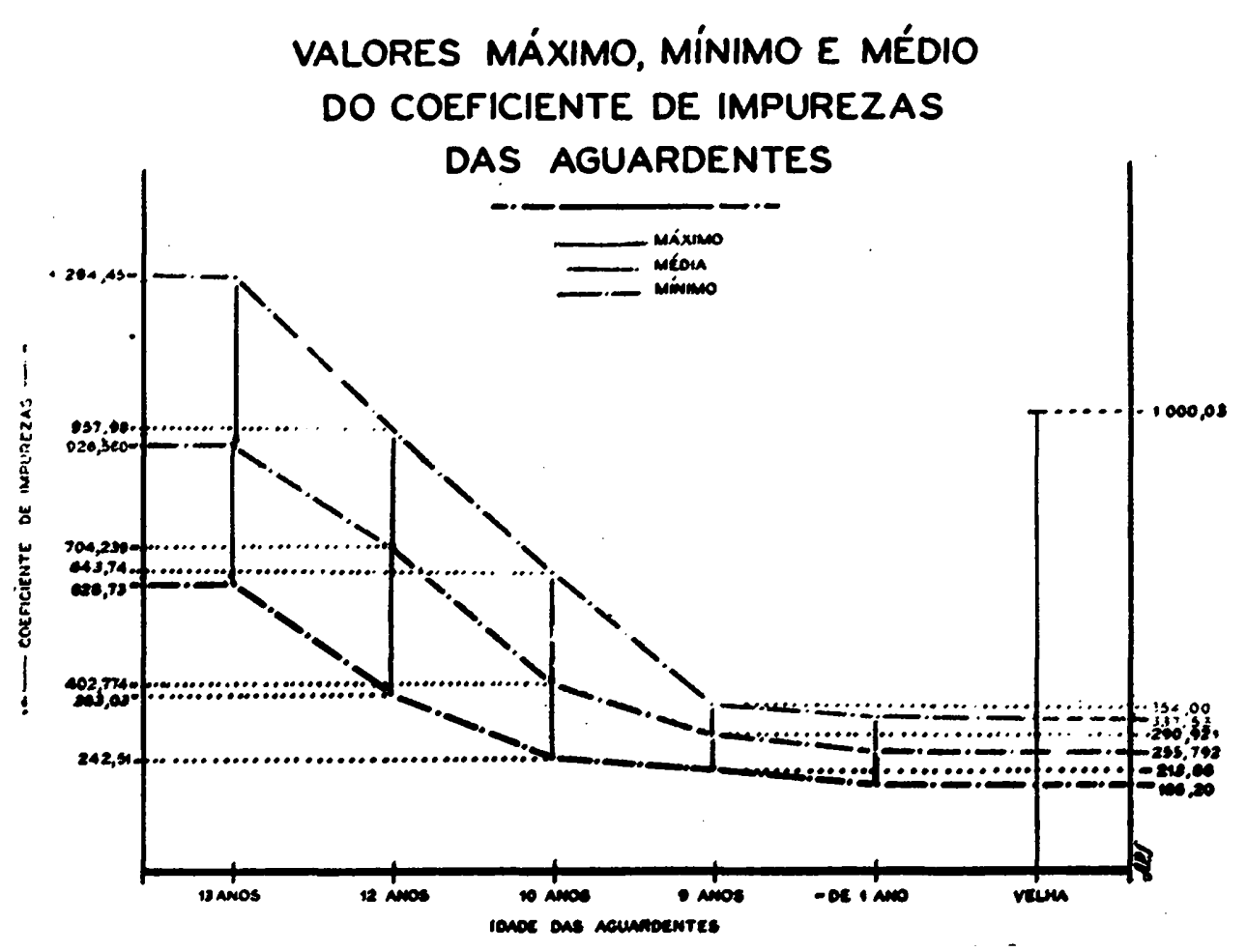


L.USSON e ROCQUES estabeleceram o coeficiente de oxidação pars os conhaques franceses, segundo a expressăo:

$$
\text { a!de!́os - ácidos } \times 100
$$

impurezas totais

Essta relaçáo é muito importante para se aquilatar da qualicade dos conhaques velhos, pols deve aumentar com a idade. embora náo seja o acréscimo proporcional ao tempo de conservaçáo. Para efeito comparativo, dando-se as impurezas iotais o valor 100 , o coeficiente de oxidaçăo será de 10 a 15 nas aquardentes novas, recém distlladas, podendo variar de 30 a 35 . aas velhas. Valores maiores que 35 revelam aguardentes de compnsiç.jo anormal.

Procurando verificar se este coeficiente poderia se aplicar às aguardentes pelos autores examinadas, resultaram os seguintes: dados :

\section{QUADRO XXI}

\begin{tabular}{|c|c|c|c|c|c|}
\hline $\begin{array}{l}\text { N.o da } \\
\text { amostra }\end{array}$ & $\begin{array}{l}\text { Coeficiente } \\
\text { de oxidaquo }\end{array}$ & $\begin{array}{l}\text { N.o da } \\
\text { amostra }\end{array}$ & $\begin{array}{c}\text { Coeficiente } \\
\text { ic oxidaq̧o }\end{array}$ & $\begin{array}{c}\text { N.o da } \\
\text { amostra }\end{array}$ & $\begin{array}{l}\text { Coeficiente } \\
\text { de oxidaç̃o }\end{array}$ \\
\hline $\begin{array}{r}5 \\
6 \\
7 \\
8 \\
9 \\
10 \\
11 \\
12 \\
\text { Média }\end{array}$ & $\begin{array}{l}27,16 \\
13,15 \\
15,28 \\
24,45 \\
21,728 \\
\\
17,56 \\
15,71 \\
14,84 \\
14,07 \\
13,64 \\
12,00 \\
11,64 \\
13,37 \\
13,625\end{array}$ & $\begin{array}{r}13 \\
14 \\
15 \\
16 \\
17 \\
18 \\
19 \\
20 \\
21 \\
22 \\
23 \\
24 \\
25 \\
26 \\
27 \\
28 \\
29 \\
\\
\text { Média }\end{array}$ & $\begin{array}{r}13,51 \\
11,71 \\
12,32 \\
17,43 \\
19,34 \\
11,16 \\
20,59 \\
15,52 \\
12,42 \\
13.23 \\
16,96 \\
24,02 \\
18.18 \\
10.79 \\
12,39 \\
9.02 \\
13,64 \\
14,550\end{array}$ & $\begin{array}{c}30 \\
31 \\
32 \\
33 \\
34 \\
35 \\
\text { Média } \\
\\
36 \\
37 \\
38 \\
\text { Média } \\
39 \\
40 \\
41 \\
42 \\
43 \\
\text { Média } \\
44\end{array}$ & $\begin{array}{c}14,40 \\
13,04 \\
15,10 \\
20,21 \\
20,99 \\
16,98 \\
15,99 \\
- \\
= \\
= \\
20,70 \\
16,16 \\
16,97 \\
21,28 \\
17,55 \\
18,532 \\
21,16\end{array}$ \\
\hline
\end{tabular}

Coefjciente de oxidação das aguardentes 
Pira meihor $€$ mais fácil julgamento, resumimos no quadro ałaixo, os valores médio, máximo e mínimo das aguardentes craminadas, separadamente, por idade. conforme se vê abaixo :

Idade

Média Máximo Mínimo

13 ano

21,728

27.16

13.15

12 ann

13.625

17,56

11,64

10 ancs

14,550

24,02

9,02

9 anos

15,99 ?

2099

13.71

mencs de 1 ano ................ 18.5.39.

21,28

16,16

Velha

21,15

Comu se pederá observar, os resultados foram por demais dispanato:os para se poder tirar qualquer conclusão acertada. Năo cibstante, a ser correta a aplicaçăo do coeficiente de oxidaçăo de LIJSSON e ROCQUES a tódas as aguardentes, só podemos adm'tir que o sistema de envelhecimento das amostras examinadas foi defeituoso, coisa aliás já por várias vezes por nós snlientada. pois o referido coeficiente de oxidaçăo, por via de regra. manteve-se dentro dos limites de 10 a 15, com valores médios s:mpre superiores a 10 , caracteristicos de aguardentes ainda novas

A ar'ostra n.o 4, que foi a única conservada normalmente em barril de 100 litros, de madeira, acusou apenas 24 de coeficiente de oxidaçáo à despeito de ter 13 anos de idade.

Somos, por isso, levados a crer que o referido coeficiente de oxidaçăo te LUSSON náo se pode aplicar indistintamente a tôdas as aguardentes, a năo ser que se modifiquem os valores apontados pelos autores referidos.

Nao ubstante as consideraçס̃es diversas tecidas ao redor ào coeficiente de impurezas, nem sempre é fácil só por mei dêle distinguir um produto genuino de um obtido a partir do álcoul. Daí a vantagem de se complementar ou preceder a análise quimina com as provas de degustação.

\section{CONCLUSOES}

1 - A rîr, por si só, năo é critério seguro para julgamento da sdauc de uma aguardente, porquanto, embora seja verrade que ela adquire durante o envelhecimento uma coloraça mais ou menos acentuada, pela adiçăo de extr. ${ }^{+} 0$ de carvalho numa aguardente recém distilada, conseg'rem-se os mesmos resultados. 
2 - Em igualdade de condições, a intensidade colorimétrica Je uma aguardente vai depender da natureza da madeira e das condições de armazenamento.

3 - Pelos inúmeros resultados experimentais obtidos pelos autores. náo resta a menor dúvida que a facilidade de fermentação, a resistencia do levedo, o rendimento e a qualidade da aguardente, sáo fatores dependentes da variedade de cana.

Em, aditamento, presumimos que a variedade de cana ters também influência sôbre a alteraçăo da composicás da aguardente submetida ao envelhecimento.

4 - Todos as fenómenos de envelhecimento das aguardentes são acompanhados pela diminuição do seu volume, que se dá de mancira continua e lenta, porém, dependente das condiçóes de acondicionamento e ambiência.

5 - Durante o envelhecimento da aguardente, pela evaporaçăo, a graduaçăo alcoólica é profundamente afetada, va:iando para mais ou para menos, segundo o estado higromét:ico a a temperatura do local de armazenamento to vasilhame.

6 - O péso especiß̄ico da aguardente é inversamente proporcicinal à sua graduaçăo alcoblica, mas diretamente proporcional 20 extrato, uma vez que ele é o indicador da proporear de impurezas dissolvidas presentes na aguardente.

7 - As aguardentos que revelam alto peso especifico ao lado de alta graduaçăo alcoblica, năo podem sèr consideradas aguardentes velhas, mas podem ser admitidas como aguardentes artificialmente coloridas com o fim de mascarar a sua idade, tornando-se aparentemente velhas.

8 - Qui nt? mais velha for uma aguardente maior será o seu extrato, pois éste é fruto direto da açáo dissolvente da aguardente sóbre as matérias extrativas soluveis da madeira Năo obstante, considerado isoladamente, o extrato năn tem valor na decisăo da idade de uma aguardente, pois nada mais fácil que fazê-lo variar à vontade para mis ou para menos artificialmente. 
9 - Durante o envelhecimento natural, as aguardentes se enriquecem de acides tanto por via física (dissoluçáo do tanino e matérias tanóides), como por via quimica (ação oxirante do oxigénio do ar), porém, nunca por via biológica (açăa microorgânica).

10 -. Os ésteres originados durante o envelhecimento, pela açূূ̆o dos ácidos sóbre os alcoóis, são os principais fatores do "bouquet" de uma aguardente, razăo pela qual. tudo se deve tazer para que a eterificaçăo de uma ag "ardente em conservaçăo năo seja limitada.

11 - Pelo arejamento aumenta-se a formaçăo dos ésteres apressando o seu envelhecimento e melhorando as suas qualidsdes organolépticas.

12 - Pela elevada proporçăo de alcobis superiores normalmente presentes numa aguardente, deve-se considerar como de alto valor discriminativo a sua indicação analítica.

13 -. Nă. săo os alcodis superiores o elemento responsável pelas funestas consequencias do alcoolismo, mas sim à elevada \% de álcool etilico ingerida.

14 - Os aldeidos aparecem sempre em elevada \% nas aguarierites brasileiras, em consequéncia da prática comum de năn se separar os produtos de cabeça durante a distllaç̌. Sencio éles produtos intermediários da oxidaçăo do álcuol o seu teor cresce com o tempo de conservaçăo, pols à merlida que a aguardente envelhece eleva-se a proporçăo dos seus produtas de oxidação.

15 - A idade, pouca ou nenhuma influencia tem sóbre a quantidiade de furfurol numa aguardente, a qual varia extraorfinàriamente com o modo de tratamento do vinho : ser distilado. Vinhos turbinados ou filtrados antes da distilacáo dio sempre aguardentes mais pobres em furfurol romparativamente ao mesmo vinho distilado sem este tratamento.

16 - Apesar da proporção do coeficiente de impurezas ser muito variával, as aguardentes de boa qualidade, por via te reg"a, acusam um coeficiente elevado, nunca inferior a 200 miligramos.

17 - O coeficiente de oxidaçáo de LUSSON-ROCQUES não po.ie sar aplicado indistintamente a qualquer classe de aguardente, reservando-se especificamente para os conhiques. 


\section{SUMMARY}

1 - Colnur, by itseif, does not constitute a solid ground for jucging of the age of a brandy because the more or less prrnounced colour it acquires through aging can also be obteined by the addition of oack essence to newly distilled brandy.

2 -. Urder the same conditions. colour intensity of a brandy will depend upon the nature of the wood and the condition of the storage.

3 - In accordance with the experimental results obtained by the present writers it rests no doubt that fermentation fac.lity ferment resistence, produce and quality of the brendy a!l are factors depending upon the variety of the sugar calse. In addition, the authors presume that the variety of sugar cane has also influence upon the alteration of composition of the brandy submitted to aging.

4 -. All aging phenomena of the brandy are accompanied by volume decreasing, what happens in a slow and contiauous manner depending upon storage and environment conritions.

5 - During brandy aging the alcoholic degree is greatly affected by evaporation, increasing or decreasing in acco:dance to the hygrometric state of the air and the termperature in the place where the tuns are stored.

6 - The specific weight of the brandy is inversely proportional to its alcoholic degree, but directly proportional to. the extracts since the latter indicates the amount of dissolved residues.

7 - Brandy which shows high specific weight together with high alcoholic degree cannot be considered as aged. It may, however, be takens for brandy artificially colou'red in order to conceal its actual age.

8 - The aincount of extracts increases with aging, since it is the result of the solvent action of the brandy upon the sol:?ble extractive substances of the wood. Notwithstandir. 3 that the extract, considered alone, has no value in determining the age of a brandy, since nothing easier is inan ts rake it change artificially. 
9 -. During aging the brandy get acidity in physiological as well as in physical way, but never by the action of micr.organisms.

10 -. Tre esthers produced during aging by the action of acids upon alcrhols are the mean factors of the savour (bouquet) of $a$ brandy and therefore every thing shall be done tor ihf estherification of a preserved brandy being not limited.

11 - Aëraticn increases esther formation, reduces the agingtir:e and turn better the taste qualities of the brandy.

12 - Due to the great proportion of high alcohols ordinarily folind in the brandy, their analytical discrimination will be greatly important.

13 -.. The high alcohols are not responsable for the disastrous consequences of the alcoholism, but the high percentage of ethyl alcohol present in the brandy.

14 - Thi, aldehydes appear always in high rate in the brazilian brandys in consequence of some intermediary products of the oxydation of the alcohols being left in the brandys during aging.

15 - The age has little or no influence on the quantity of phurphurol present in a brandy whose amount varies greatly tine manner in which the wines to be distilled are treated. Wines centrifugalized or filtered before distillation always give rise to brandys poorer in phurphurol as compared with those distilled without these treatments.

16 - Thrugh greatly variable, brandys of good qualities generally show a high residues coefficient, never under 200 mnig

17 - Lusson - Rosques oxydation coefficient cannot be indiscriminately applied to any brandy class, being, on the contrary, specifically destined to cognacs. 


\section{BIBLIOGRAFIA}

ALMEIDA, Jayrne Rocha de - 1935 - Fabricação do álcool e da pinga de banana, Rev. ie Agric., vol. 10, p. 125.

ALMEIDA, Jayme Rocha de - 1940 - Alcool e distilaria.

BAUDOIr!, A - 1893 - Les eaux-de-vie.

BOTELHO, Jac: - 1945 - Impurezas do álcool etilico, Bras. Açuc., ano XIII, n. 6, p. 99.

BOULl.ANGER, Eugenic - 1929 - Destilaria agricola e industrial

CALVET, Louis M. - 1941 - Alcools.

MARTINEZ, Julia Elena - 1941 - El cognac.

PAC(:TTET. ?. e GUITTONNEAU L. - 1922 - Aguardientes y vinakres

TAVEIRA, Marjo - 1937 - Sóbre a regulamentação das bebidas fortemente alcoblicas, 3.0 Congr. Sul Amer. de Quimica, vol. VI, 7.a Sec., p. 713.

VILIAAVFCCHIA, Victor - 1919 - Tratado de Quimica analfiCir aplicede. 